\title{
Earth's Impact Events Through Geologic Time: A List of Recommended Ages for Terrestrial Impact Structures and Deposits
}

\author{
Martin Schmieder ${ }^{1,2}$ and David A. Kring ${ }^{1,2}$
}

\begin{abstract}
This article presents a current (as of September 2019) list of recommended ages for proven terrestrial impact structures $(n=200)$ and deposits $(n=46)$ sourced from the primary literature. High-precision impact ages can be used to (1) reconstruct and quantify the impact flux in the inner Solar System and, in particular, the Earth-Moon system, thereby placing constraints on the delivery of extraterrestrial mass accreted on Earth through geologic time; (2) utilize impact ejecta as event markers in the stratigraphic record and to refine bio- and magnetostratigraphy; (3) test models and hypotheses of synchronous double or multiple impact events in the terrestrial record; (4) assess the potential link between large impacts, mass extinctions, and diversification events in the biosphere; and (5) constrain the duration of melt sheet crystallization in large impact basins and the lifetime of hydrothermal systems in cooling impact craters, which may have served as habitats for microbial life on the early Earth and, possibly, Mars. Key Words: Impact craters-Ejecta-Ages-Geochronology—TerrestrialCratering record. Astrobiology 20, 91-141.
\end{abstract}

\section{Introduction}

MPACT CRATERING is a fundamental process in the Solar System, shaping asteroids, planets, and their satellites (e.g., Baldwin, 1971; Shoemaker, 1983; Melosh, 1989; Ryder, 1990; French, 1998, 2004; Canup and Asphaug, 2001; Kring and Cohen, 2002; Osinski and Pierazzo, 2012). Unlike the Moon, whose surface has been modified by numerous large and small impacts for more than 4 billion years $(\mathrm{Ga}$, Gyr) (e.g., Stöffler et al., 2006), the Earth has retained a limited impact cratering record due to tectonic recycling of the crust, erosion, and the burial of impact craters underneath layers of sediment and lava (e.g., Grieve, 1987, 2001a, 2001b) (Fig. 1).

Before $\sim 3.7 \mathrm{Ga}$ before present, when most of the large lunar impact basins were created, impact rates in the EarthMoon system were much higher than they are today (e.g., Turner et al., 1973; Tera et al., 1974; Ryder, 1990; Kring and Cohen, 2002; Grieve et al., 2006; Johnson and Melosh, 2012; Bottke and Norman, 2017). However, no traces of those Hadean (>4.0 Ga) and Eoarchean (4.0-3.6 Ga) impacts on the early Earth are currently known in the geologic record (e.g.,
Koeberl, 2006). Only 200 proven impact structures (counting fields of small impact craters produced during the same event as one) and 46 individual horizons of proximal and distal impact ejecta (again, counting layers with the same age at different localities as one) have thus far been recognized on our planet (Fig. 2). Those impact structures and deposits span a time from more than $\sim 3.4 \mathrm{Ga}$, represented by Paleoarchean impact spherule layers in South Africa and Western Australia produced by large impacts (e.g., Glass and Simonson, 2012, 2013), to roughly 6 years ago when the Chelyabinsk airburst in Russia (February 15, 2013) shattered windows and its main stony meteorite mass produced an $\sim 7 \mathrm{~m}$-wide circular impact penetration hole in frozen Lake Chebarkul (e.g., Borovička et al., 2013; Popova et al., 2013).

The smallest geologic features on Earth's surface produced by impact, usually only a few meters wide and commonly associated with surviving meteorite fragments, are (fields of) penetration funnels, pits, and small craters that form at relatively low, atmosphere-decelerated (ballistic) impact velocities (e.g., Melosh, 1989; Beauford, 2015). Some of the impact structures listed in this article belong to that type of low-energy impact feature (e.g., the crater-like pits produced

\footnotetext{
${ }^{1}$ Lunar and Planetary Institute-USRA, Houston, Texas.

${ }^{2}$ NASA Solar System Exploration Research Virtual Institute (SSERVI).

(c) Martin Schmieder and David A. Kring, 2020; Published by Mary Ann Liebert, Inc. This Open Access article is distributed under the terms of the Creative Commons License (http://creativecommons.org/licenses/by/4.0), which permits unrestricted use, distribution, and reproduction in any medium, provided the original work is properly credited.
} 

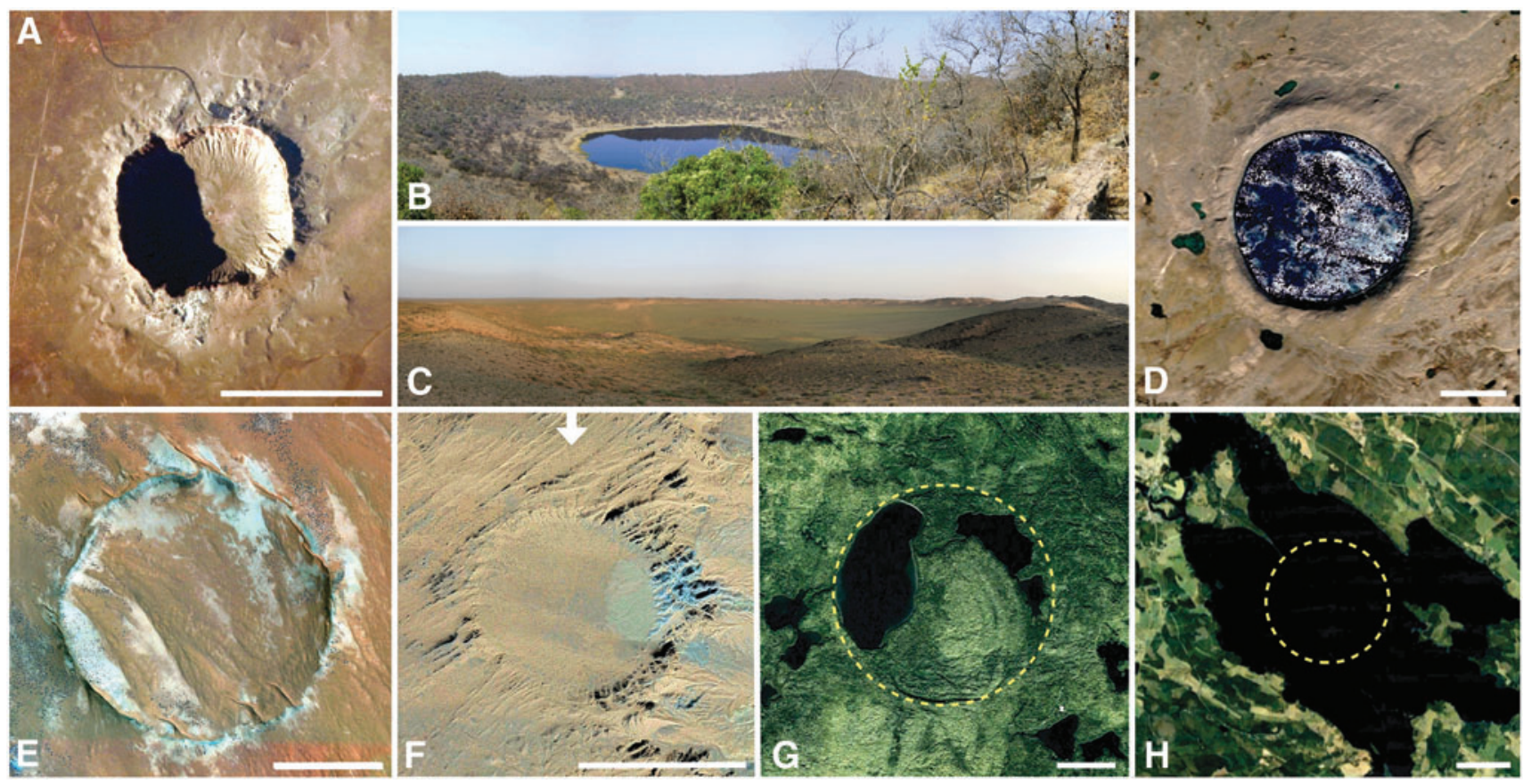

FIG. 1. Degradation of terrestrial impact craters over time, exemplified by a number of simple, bowl-shaped impact craters that are most easily erased from the terrestrial impact cratering record. The same principle applies to complex impact craters on Earth larger than $\sim 2$ to $4 \mathrm{~km}$ in diameter (not shown here). (A) The $\sim 1.2 \mathrm{~km}$-diameter and roughly $50 \mathrm{kyr}-\mathrm{old}$ Meteor Crater ( $a k a$ Barringer Meteorite Crater) in Arizona is one of the best-preserved simple impact craters on Earth (e.g., Shoemaker, 1960; Kring, 2017b). Its ejecta blanket forms a hummocky terrain surrounding the crater. Note the pronounced topography of the crater indicated by low-angle sunlight coming from the WSW. ISS spacecraft image ISS-038-E-67508. (B) The $1.13 \mathrm{~km}$-diameter and $220 \mathrm{kyr}$-old Tswaing impact crater in South Africa (e.g., Brandt and Reimold, 1995), with its crater bowl seen from the uplifted crater rim. After more than 2000 centuries of erosion, its topographic features have been smoothed out considerably compared with Meteor Crater. Photo taken during 2008 field expedition. (C) The $\sim 1.3 \mathrm{~km}-$ diameter Tavan Khar Ovoo (aka Tabun Khara Obo) impact crater in Mongolia (Masaitis, 1999; Schmieder et al., 2013). The crater rim is less pronounced than those at Meteor Crater and Tswaing, and the crater bowl is filled with a thick pile of postimpact sediments, mainly lake sediments and alluvium. The age of the crater is somewhat uncertain but likely on the order of a few Myr. Photo taken during 2011 field expedition. (D) Satellite image of the $\sim 3.4 \mathrm{~km}$-diameter and $\sim 1.1 \mathrm{Myr}-$ old New Québec (Pingualuit) impact crater in Canada (e.g., Grieve et al., 1991; Marvin and Kring, 1992; Grieve, 2006), with parts of its elevated crater rim preserved despite Pleistocene glacial overprint. The crater is filled with a modern-day lake. (E) The $\sim 2.5 \mathrm{~km}$-diameter and $\sim 4$ to 5 Myr-old Roter Kamm impact crater in Namibia (e.g., Grant et al., 1997; Miller, 2010). After a few million years of surface exposure, the crater has been modified by notable degradation and postimpact sediment infill. (F) Satellite view of the Tavan Khar Ovoo crater shown in (C), characterized by a level of erosion similar to that of the New Québec crater and the Roter Kamm crater. (G) Satellite image of the $3.8 \mathrm{~km}$-diameter and 453 Ma Brent crater in Canada, filled with postimpact sediments and today partly occupied by lakes. After several hundred Myr, this crater (dashed circle) is vaguely recognizable by its morphology, and most of the impact crater geology is known from drillings (Grieve, 1978, 2006). (H) Satellite image of the recently discovered $\sim 2.6 \mathrm{~km}$-diameter Summanen impact structure in Finland of uncertain age (Plado et al., 2018). After perhaps hundreds of millions of years of exposure, the crater (dashed circle) has been significantly overprinted by erosion, sedimentary infill, and glaciation and is today concealed by a lake. The discovery and characterization of such old, "invisible" small impact structures usually requires detailed geologic mapping and field work, as well as drilling. Scale bars are $1 \mathrm{~km}$.

during the fall of the Imilac pallasite in Chile, or the temporary Chalyabinsk ice-penetration hole, which we chose to include in the present listing). Hypervelocity impacts of larger meteoroids, at much higher incoming velocities, produce craters that show different morphologies with increasing size (e.g., Melosh, 1989; French, 1998). A textbook example of a well-preserved simple, bowl-shaped impact crater associated with its ejecta blanket is the $\sim 1.2 \mathrm{~km}$-diameter Meteor Crater (a.k.a. Barringer Meteorite Crater) in Arizona (Shoemaker, 1960; Kring, 2017b) (Fig. 1). Earth's impact craters larger than $\sim 2$ to $4 \mathrm{~km}$ in diameter are of complex morphology and structure, such as the $\sim 3.8 \mathrm{~km}$-diameter Steinheim Basin in Germany characterized by a pronounced central peak (uplift) and the $\sim 25 \mathrm{~km}$-diameter Nördlinger Ries with an $\sim 10 \mathrm{~km}$-wide inner ring of uplifted target rock and a well-preserved blanket of proximal impact ejecta surrounding the crater (e.g., Stöffler et al., 2002, 2013; Kring, 2005; Schmieder and Buchner, 2013). The $180 \mathrm{~km}$-diameter Chicxulub crater on the Yucatán Peninsula in Mexico is a peak-ring basin similar in morphology and structure to the Schrödinger Basin on the Moon (Kring, 1995; Kring et al., 2016, 2017a; Morgan et al., 2016). The deeply eroded Vredefort impact structure in South Africa, probably $\sim 250$ to $300 \mathrm{~km}$ in original diameter, may represent the remnants of a terrestrial multiring basin (e.g., Melosh, 1989; Spudis, 1993; Therriault et al., 1997; French, 1998). 


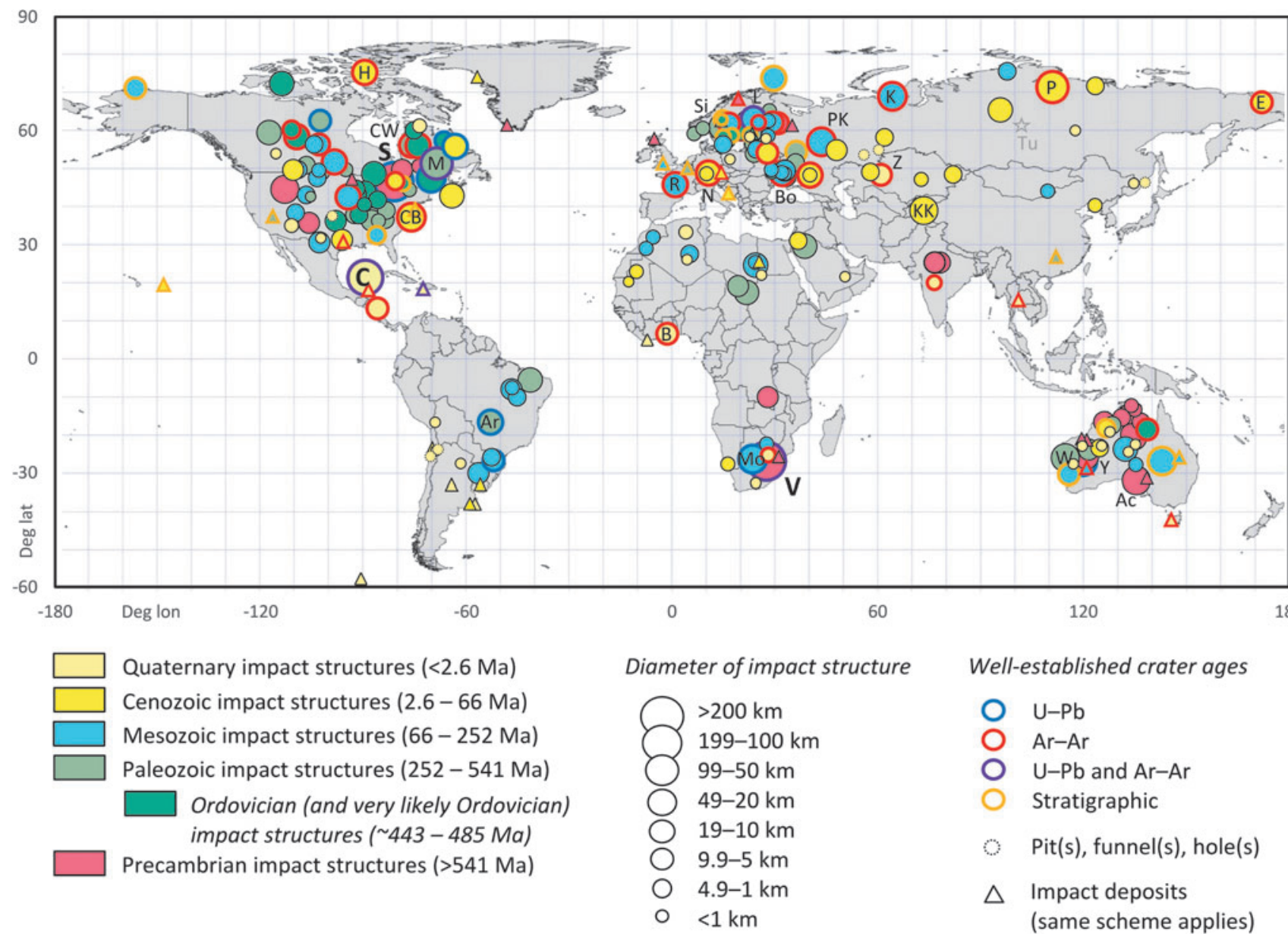

FIG. 2. Map of impact structures $(n=200)$ and deposits $(n=46)$ on Earth (including prominent impact holes, funnels, and pits) and their best-estimate ages. For poorly constrained ages, the stratigraphic maximum age was chosen. Only a few representative ejecta localities are shown (e.g., Thailand for the Australasian tektite strewn field) because some distal ejecta deposits, such as the end-Cretaceous Chicxulub ejecta (plotted at Beloc, Haiti; yellow-green symbols) or the Popigaiderived Upper Eocene clinopyroxene spherules (plotted near Hawaii), have a global or semiglobal distribution. Some prominent terrestrial impact structures are labeled as follows: Ac, Acraman; Ar, Araguainha; B, Bosumtwi; Bo, Boltysh; C, Chicxulub; CB, Chesapeake; CW, West and East Clearwater Lake; E, El'gygytgyn; H, Haughton; K, Kara; KK, Kara-Kul; L, Lappajärvi; M, Manicouagan; Mo, Morokweng; N, Nördlinger Ries; P, Popigai; PK, Puchezh-Katunki; R, Rochechouart; S, Sudbury; Si, Siljan; V, Vredefort; W, Woodleigh; Y, Yarrabubba; Z, Zhamanshin. The gray star symbol marks the site of the June 30, 1908, Tunguska (Tu) explosion that downed trees in a vast area but left no impact structure on the ground. Compare Table 1 with ages for impact structures and Table 2 with ages for impact deposits.

To assess the temporal distribution of impact events and calculate impact rates as an expression of the impact flux through time, different geochronologic techniques have been developed and applied. These include, first, crater counting and the calculation of isochrons based on the crater size-frequency distribution for the Moon, Mars, and other planetary bodies characterized by a crater production record (e.g., Hartmann and Neukum, 2001; this technique is not applicable to the geologically active Earth); second, stratigraphic age constraints (e.g., Koeberl et al., 2001; Lindström et al., 2005; Schmieder and Buchner, 2008); third, isotopic age determinations using the $\mathrm{U}-\mathrm{Pb}, \mathrm{Ar}-\mathrm{Ar}$ $(\mathrm{K}-\mathrm{Ar}), \mathrm{Rb}-\mathrm{Sr}$, and $(\mathrm{U}-\mathrm{Th}) / \mathrm{He}$ geo-/thermochronometers and/or the ${ }^{14} \mathrm{C}$ method with impact lithologies sampled in natural outcrop or drillings on Earth, in meteorites, or samples returned from space missions (e.g., Tera et al., 1974; Bottomley et al., 1990; Deutsch and Schärer, 1994; Jourdan et al., 2009, 2012); and, finally, methods other than those mentioned above. We here predominantly focus on the stratigraphic and isotopic methods. Due to improvements in $\mathrm{U}-\mathrm{Pb}$ (e.g., chemical abrasion thermal ionization mass spectrometry [CA-TIMS]) (Schoene, 2014; Kenny et al., 2019a), secondary ion mass spectrometry (SIMS) (Kenny et al., $2019 \mathrm{~b}$ ), and ${ }^{40} \mathrm{Ar}-{ }^{39} \mathrm{Ar}$ geochronologic instrumentation and methods (e.g., Renne et al., 2010, 2011, 2013; Sprain et al., 2015; Schmieder et al., 2018a), the most precisely constrained "impact ages" today come with uncertainties on the thousands-of-years (ka, kyr) level.

This article provides a current (as of September 2019) summary of predominantly stratigraphic and isotopic recommended ages for proven impact structures and deposits on Earth. Structures and deposits of likely but, to some degree, uncertain impact origin (e.g., numerous oblong depressions near Rio Cuarto in Argentina; Schultz and Lianza, 
1992; cf. Cione et al., 2002; Reimold et al., 2018; Crósta et al., 2019c; the recently reported Hiawatha "impact crater" in Greenland; Kjær et al., 2018; and enigmatic glass deposits such as the Edeowie glass found in South Australia; Haines et al., 2001; glasses found near Dakhleh, Egypt; Osinski et al., 2008; and the Pica glass found in the Atacama Desert of Chile; Roperch et al., 2017) are, therefore, not included. Likewise, the 1908 Tunguska airburst event in Russia, which seemingly did not produce any geologic feature other than uprooted trees, is not listed here (e.g., Kulik, 1940; Krinov, 1960). The present article does not intend to be the latest reference pertaining to the formation of simple and complex impact craters, their impact ejecta, and the physical aspects of the cratering process (e.g., Melosh, 1989; Melosh and Ivanov, 1999; Osinski et al., 2011, 2012; Kenkmann et al., 2012), the petrology of impactites (rocks produced or modified by impact) (e.g., French, 1998; Stöffler and Grieve, 2007; Grieve and Therriault, 2012), or the verification of impact structures through the identification of macro- and microscopic shock-metamorphic features (e.g., shatter cones and shocked quartz and zircon grains) (French, 1998; French and Koeberl, 2010; Ferrière and Osinski, 2012). For details about the more specific geologic features of terrestrial impact structures, we refer the reader to a number of review articles that summarize the impact cratering record of each continent on Earth, such as the works of Grieve (2006) for Canada in North America, Reimold et al. (2018) and Crósta et al. (2019b) for South America, Schmieder and Buchner (2013) for Europe, Reimold and Koeberl (2014) and Chabou (2019) for Africa and the Arab World, respectively, Masaitis (1999) and Reimold et al. (2008) for Russia and Asia, and Haines (2005) for Australia. [Somewhat surprisingly, there is currently no up-to-date review of the impact cratering record of the United States, and Walter H. Bucher's (1936) early work on the country's "cryptoexplosion structures" probably remains the most recent systematic review of its kind; however, many impact structures in the United States were included in the more general listings of Freeberg (1969), Classen (1977), and Grolier (1985), and a website project maintained by Beauford (2019) provides basic information and the relevant literature for almost all impact structures and crater fields recognized in the country.] Nor does this relatively short summary provide an in-depth explanation and discussion of the isotopic methods commonly used to determine impact ages, such as the $\mathrm{U}-\mathrm{Pb}$ and $\mathrm{Ar}-\mathrm{Ar}$ geochronometers. In this context, we recommend the comprehensive summaries on the U-Pb technique by, for example, Corfu (2013) and Schoene (2014), and on the Ar-Ar (and K-Ar) method by McDougall and Harrison (1999) and Kelley (2002). Previous U-Pb, Ar-Ar, and $\mathrm{Rb}-\mathrm{Sr}$ geochronologic work on several terrestrial impact structures includes that of Bottomley et al. (1990) and Deutsch and Schärer (1994), from which much was learned regarding how different geochronometers behave with different types of impact crater materials analyzed. This summary builds upon that previous work, including critical evaluations of Earth's impact crater ages that ensued (Jourdan et al., 2009, 2012; Jourdan, 2012). It should serve as a robust geochronologic database and a backbone for ongoing and future studies that make use of Earth's impact crater ages for, for example, statistical calculations and cratering flux models (e.g., Mazrouei et al., 2019). Such studies have, in part, relied on a flawed representation of the terrestrial impact cratering record with partly inaccurate ages as input parameters (e.g., Telecka and Matyjasek, 2011; and the recently published Encyclopedic Atlas of Terrestrial Impact Craters of Flamini et al., 2019 that lists numerous inaccurate impact ages), inevitably compromising the validity and significance of their conclusions (see also discussions in Miljković et al., 2013, 2014; Schmieder et al., 2014c; Rampino and Caldeira, 2015; Meier and Holm-Alwmark, 2017). Finally, this work presents a referenced source for current best-estimate ages that can be listed in online impact databases, such as the Earth Impact Database (hosted at the University of New Brunswick, Fredericton, Canada), which has recently been complemented by the database Impact Earth maintained by Osinski and Grieve (2019).

\section{Data and Methods}

Stratigraphic, isotopic, and additional age constraints are predominantly sourced from the primary literature, highlighting the work that led to the establishment of the (currently) preferred age for any particular impact event. Some ages are taken from summary articles (e.g., Grieve, 2006). Impact ages are grouped into three main categories: (1) stratigraphic age constraints; (2) isotopic ages, including $\mathrm{U}-\mathrm{Pb}$, Ar-Ar, $\mathrm{K}-\mathrm{Ar}, \mathrm{Rb}-\mathrm{Sr}$, (U-Th)/He, and ${ }^{14} \mathrm{C}$ ages (while considering ages obtained using the high-temperature $\mathrm{U}-\mathrm{Pb}$ and $\mathrm{Ar}-\mathrm{Ar}$ geochronometers are usually preferred); and (3) age constraints other than the ones mentioned above.

\subsection{Stratigraphic ages}

The determination of relative stratigraphic ages, by superposition, can be applied to all impact structures on Earth and elsewhere, where the age of the host rock is to some degree constrained. Every impact structure has a target rock that the impacting body penetrated and, through simple geologic cross-cutting relationships, the youngest rock units affected by the impact provide a maximum (oldest possible) age for the impact. In turn, the oldest undisturbed rocks that fill the crater after its formation, commonly crater lake sediments in continental paleosettings, constrain the minimum (youngest possible) impact age. Some terrestrial impact crater ages are only very imprecisely constrained by the age of the impacted target rock as a maximum age (e.g., the $<1800$ million years [Ma, Myr] Île Rouleau impact structure, Québec, Canada) (Grieve, 2006). Sometimes, the stratigraphic age for an impact can only be bracketed within several hundred million years, as in the case of the $12 \mathrm{~km}-$ diameter Wells Creek impact structure in Tennessee (e.g., Wilson, 1953; Ford et al., 2012; Ford, 2015, and references therein). The crater must be younger than Mississippian ( $\sim 323 \mathrm{Ma})$ and older than Late Cretaceous ( $\sim 100 \mathrm{Ma})$ (see Cohen et al., 2013, for current stratigraphic age values), suggesting a "best-estimate" age of $\sim 211 \pm 111 \mathrm{Ma}$ and a relative error on the age of $>100 \%$ (the commonly published age is 200 $\pm 100 \mathrm{Ma}$ ) (e.g., Grieve, 2001a). However, other stratigraphically constrained impact ages are remarkably precise, such as that of the $\sim 14 \mathrm{~km}$-wide marine Lockne crater in Ordovician rocks of Central Sweden. There, the impact age is precisely constrained to be $455 \mathrm{Ma}$ plus and minus a few hundred thousand years, because both the 
youngest preimpact and oldest postimpact sediments lie in the late Sandbian (early Caradocian) lower Lagenochitina dalbyensis chitinozoan microfossil zone studied in great detail (Grahn et al., 1996; Grahn, 1997; Ormö et al., 2014). The stratigraphic method equally applies to impact ejecta layers.

\subsection{Isotopic ages}

Both the Wells Creek and Lockne impact craters described above have no or little recognized impact melt, respectively, that could potentially be used as material for radioisotopic analysis. However, a relatively large number of terrestrial impact structures have preserved impact melt-bearing rocks (e.g., Dence, 1971; von Engelhardt, 1984; Dressler and Reimold, 2001; Stöffler and Grieve, 2007; Osinski et al., 2018), such as the up to $\sim 2.5 \mathrm{~km}$-thick, differentiated crystalline melt sheet (the Sudbury Igneous Complex) overlain by $\sim 1.5 \mathrm{~km}$ of meltbearing impact breccia (the Onaping Formation) at the $\sim 200$ to 250 km-diameter Sudbury Basin in Ontario, Canada (e.g., Grieve, 2006; Davis, 2008; Rousell and Brown, 2009; Grieve et al., 2010); the up to $\sim 1.2 \mathrm{~km}$-thick melt sheet at the $100 \mathrm{~km}$-diameter Manicouagan impact structure in Québec, Canada (e.g., Floran et al., 1978; Grieve, 2006; Spray et al.,
2010) (Fig. 3A); and the up to $\sim 250 \mathrm{~m}$-thick melt-bearing impact breccia (suevite) of the $25 \mathrm{~km}$-diameter Nördlinger Ries crater in Germany (e.g., von Engelhardt et al., 1995; von Engelhardt, 1997; Stöffler et al., 2013) (Fig. 3B). The Ries impact also produced green glassy tektites (moldavites) (Fig. 3C), distal melt ejecta found $\sim 200$ to $500 \mathrm{~km}$ northeast of the crater (e.g., Stöffler et al., 2002; Trnka and Houzar, 2002). Because of the (partial to complete) resetting of geochronometers, for example, the $\mathrm{U}-\mathrm{Pb}$ and $\mathrm{K}-\mathrm{Ar}$ system, during high-temperature melting and degassing (diffusion) events such as major impacts (e.g., Jourdan et al., 2012), impact melt lithologies are in most cases suitable for geochronologic analysis using a variety of radioisotopic geochronometers.

2.2.1. U-Pb ages. One method used to determine impact ages is the uranium-lead (U-Pb) and coupled lead-lead ( $\mathrm{Pb}-\mathrm{Pb})$ geochronometer (e.g., Nier, 1939; Wetherill, 1956, 1963; Tera and Wasserburg, 1972, 1974; and see Corfu, 2013 and Schoene, 2014 for reviews of its historical development and application). The $\mathrm{U}-\mathrm{Pb}$ geochronometer is today used with several different technical setups. These include laser ablation inductively coupled plasma mass
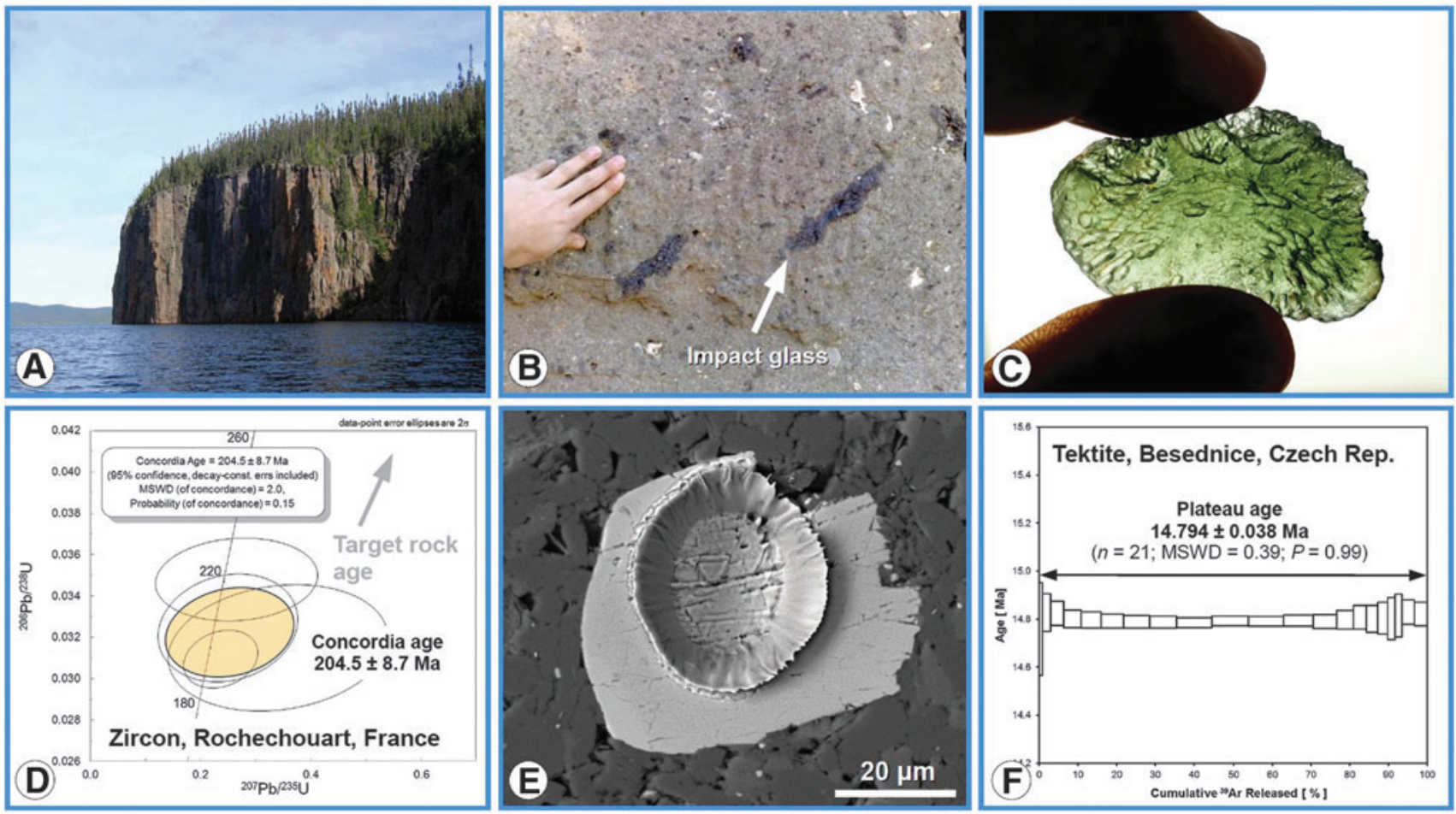

FIG. 3. Impact crater materials commonly used for geochronologic analysis and two exemplary results. (A) Approximately $100 \mathrm{~m}$-tall cliff of the impact melt sheet at the Manicouagan impact structure, Québec, Canada (Baie Memory Entrance Island, photo taken by M. Schmieder in summer 2006). This type of impact melt rock is suitable for whole-rock $\mathrm{Ar}-\mathrm{Ar}$ analysis and usually contains minerals (e.g., zircon) that can be analyzed using the U-Pb method. (B) Suevite, a polymict impact breccia with dark, elongated flädle of impact glass from the Ries crater, Germany (Katzenstein Castle near Dischingen, Baden-Württemberg). Impact glass is commonly used as sample material for Ar-Ar geochronology. (C) A green, glassy Ries tektite (moldavite) found in Besednice, Czech Republic. (D) Concordia (Wetherill) diagram showing $\mathrm{U}-\mathrm{Pb}$ geochronologic results for zircon in impact melt rock from the Rochechouart impact structure in France (unpublished data). (E) Shocked zircon grain with LA-ICP-MS laser ablation pit created during U-Pb analysis in impact melt rock from the Charlevoix impact structure, Québec, Canada (backscattered electron image) (Schmieder et al., 2019). (F) Argon-argon age diagram showing a well-defined plateau age, including relevant statistics for a Ries tektite sample similar to the one shown in (C) (from Schmieder et al., 2018a). LA-ICP-MS, laser ablation inductively coupled plasma mass spectrometry. 
spectrometry (LA-ICP-MS), SIMS (SIMS and nanoSIMS), sensitive high-resolution ion microprobe (SHRIMP) analysis, and thermal ionization mass spectrometry after chemically abrading the mineral sample for better results (CA-TIMS). The latter, again, comes in different variations (isotope dilution, ID-TIMS; and total evaporation, TE-TIMS) (e.g., Davis, 2008). Each of these techniques has its advantage and disadvantage. While LA-ICP-MS and SIMS/SHRIMP are routinely and rapidly applied to thin-section or grain mount samples that can preserve the textural context of the sample, producing moderately precise $\mathrm{U}-\mathrm{Pb}$ and $\mathrm{Pb}-\mathrm{Pb}$ ages, $\mathrm{CA}$ TIMS completely dissolves the mineral sample but produces much more precise ages with errors commonly in the range of a few thousands to tens of thousands of years (e.g., Schoene, 2014; Schaltegger et al., 2015). The U-bearing minerals most commonly used for the U-Pb geochronologic analysis of impact materials are either intensely shocked or melt-grown zircon crystals (Fig. 3D, E) (e.g., Davis, 2008; Crow et al., 2017; Kenny et al., 2019a, 2019b), baddeleyite (Krogh et al., 1984; Corfu and Lightfoot, 1996), monazite (e.g., Tohver et al., 2012; Erickson et al., 2017, 2019a, 2019b), and to a lesser degree titanite (Ames et al., 1998) and apatite, although recent results for terrestrial impact craters suggest the latter is a promising target mineral for future studies (McGregor et al., 2018, 2019). Uranium-lead results are typically visualized in a concordia diagram (Wetherill or Tera-Wasserburg plot) alongside their internal statistics (mean square weighted deviation [MSWD] and probability $p$ as a measure of statistical fit) and can be corrected for a nonradiogenic ("common") lead component. Zircon crystals from the less severely shocked, unmelted portion of the target rock of an impact structure commonly tend to yield older dates on or near concordia (the curve along which $\mathrm{U}-\mathrm{Pb}$ ages from different $\mathrm{U}$ decay series are equal), reflecting the crystallization and/or metamorphic age(s) of the host rock (e.g., Schärer and Deutsch, 1990; Wielicki et al., 2012; Schmieder et al., 2015b). In contrast, intensely shocked and recrystallized zircon grains (so-called granular zircon, locally with $\mu \mathrm{m}$-sized baddeleyite domains as a thermal decomposition product of zircon) (Wittmann et al., 2006; Timms et al., 2017) are chronometrically reset and commonly yield younger concordia ages, potentially reflecting the impact (Fig. 3D) (e.g., Hodych and Dunning, 1992; Krogh et al., 1993; Wielicki et al., 2012; Kenny et al., 2019b). If the isotopic system is affected by variable loss of $\mathrm{Pb}$, a discordant array of dates may define a lower intercept with concordia from which the age of the impact can be derived (e.g., Kamo et al., 1996; Mänttäri and Koivisto, 2001). However, episodic and/or modern postimpact $\mathrm{Pb}$ loss can cause significant disturbance of the U-Th- $\mathrm{Pb}$ system, and some zircon $\mathrm{U}-\mathrm{Pb}$ ages obtained for impact events (e.g., the Ediacaran Acraman impact in South Australia) and their geologic significance are not straightforward to interpret (Schmieder et al., 2015b). A special type of zircon is typically U- and Th-rich metamict (internally radiationdamaged, pseudoamorphous) zircon (e.g., Pidgeon et al., 1966; Meldrum et al., 1998; Nasdala et al., 2001), which is more susceptible to $\mathrm{U}-\mathrm{Pb}$-chronometric resetting during impact events (and other thermometamorphic processes) than nonmetamict zircon (e.g., Schwarz et al., 2016a and unpublished data; Stockli et al., 2018; McGregor et al., 2019; Schmieder et al., 2019). The use of metamict (do- mains in) shocked zircon grains in impact geochronology, therefore, warrants additional future research.

Uranium-lead and $\mathrm{Pb}-\mathrm{Pb}$ ages of $3470 \pm 2 \mathrm{Ma}$ for zircon crystals extracted from the Paleoarchean S1 impact spherule layer in the Onverwacht Group of the Barberton Greenstone Belt in South Africa and the Warrawoona Group of the Pilbara Block in Western Australia define the oldest impact ages on Earth (Byerly et al., 2002); a number of additional younger Archean and Proterozoic spherule layers occur in those regions and elsewhere (e.g., Glass and Simonson, 2012). Earth's oldest partially preserved impact structure is the roughly $50 \mathrm{~km}$-diameter Yarrabubba impact structure in Western Australia, with a $\mathrm{Pb}-\mathrm{Pb}$ age for shockrecrystallized monazite of $2229 \pm 5$ Ma (Erickson et al., 2019a, 2019b). Shocked zircon crystals in melt rock from the $\sim 250$ to $300 \mathrm{~km}$-diameter Vredefort impact structure, the largest one and also among the three oldest on Earth, yielded a U-Pb age of $2023 \pm 4$ Ma (Kamo et al., 1996). Zircon grains crystallized from Sudbury's impact melt sheet produced a U-Pb age of $1850 \pm 1 \mathrm{Ma}$ (Krogh et al., 1984). In a recent study, intensely shock-metamorphosed zircon grains recrystallized into microgranular aggregates yielded a precise concordia age of $77.85 \pm 0.78 \mathrm{Ma}$ for the $23-\mathrm{km}$ Lappajärvi impact crater in Finland (Kenny et al., 2019b). This result for Lappajärvi has wider biological and astrobiological implications with respect to the role particularly of medium-sized (approximately 20-30 km-diameter) impact craters as habitats for microbial life on the early Earth (e.g., Kring, 2000, 2003; Osinski, 2003, 2011; Osinski et al., 2001; Cockell et al., 2003; Cockell, 2006) and, possibly, Mars (e.g., Newsom, 1980; Rathbun and Squyres, 2002; Abramov and Kring, 2005; Rummel et al., 2014; Osinski et al., 2017) (see also discussion in Section 4).

2.2.2. Ar-Ar ages. Another technique prominently used in impact geochronology is the ${ }^{40} \mathrm{Ar}{ }^{39} \mathrm{Ar}$ (henceforth simply Ar-Ar) method pioneered by Wänke and König (1959) and Merrihue and Turner (1966), an improved variation of the classical $\mathrm{K}-\mathrm{Ar}$ technique. McDougall and Harrison (1999) and Kelley (2002) provide useful and comprehensive reviews. After sample selection, processing, and meticulous handpicking of virtually fresh and clast-poor sample splits (typically particles of impact melt rock, ideally separated into the melt groundmass and clast portion therein; impact glass; or feldspar $\leq 500 \mu \mathrm{m}$ in particle size) (e.g., Schmieder and Jourdan, 2013a; Swindle et al., 2014), the potassiumbearing rock or mineral sample, together with standard minerals, is first irradiated by fast neutrons to produce ${ }^{39} \mathrm{Ar}$ from ${ }^{39} \mathrm{~K}$ as a proxy for $\mathrm{K}$ in the sample; the argon isotope ratios in the aliquots are then measured in a mass spectrometer (i.e., thereby eliminating the need to determine a less precise ratio of absolute $\mathrm{K}$ and Ar concentrations from separate sample splits) and ages can be calculated by using the latest $\mathrm{K}$ decay constants and standard mineral ages (Renne et al., 2010, 2011). The Ar-Ar method is today most commonly applied by using the total fusion of a sample with a laser (e.g., Kelley and Spray, 1997) or, alternatively, the stepwise heating of a sample using a resistance furnace or laser (e.g., Bottomley et al., 1990; Swisher et al., 1992; Jourdan, 2012; Schmieder et al., 2018a). Generally, the stepheating method produces a more comprehensive set of data than the total-fusion method and allows for a more robust 
statistical assessment of resulting ages (e.g., Jourdan et al., 2008, 2011; Schmieder and Jourdan, 2013a).

Argon-argon results for impact structures can be disturbed by the effects of sample alteration causing the diffusive loss of radiogenic ${ }^{40} \mathrm{Ar} *$ and younger apparent ages (e.g., Schmieder et al., 2014a), and also the incorporation of inherited ${ }^{40} \mathrm{Ar} *$ with inclusions of incompletely degassed older target rock material and/or excess argon from Arbearing fluids interacting with the sample, both causing older apparent ages (inherited and excess argon are summarized under the term "extraneous argon") (e.g., Kelley, 2002). Such effects can be identified, quantified, and corrected for using the isochron approach (e.g., Roddick, 1978; Kuiper, 2002; Jourdan et al., 2008, 2011; Jourdan, 2012; Schmieder et al., 2015a). Statistically robust Ar-Ar results ideally form a "plateau" in the age spectrum (Fig. 3F), a sequence of individual degassing steps with increasing temperature that all overlap within a narrow error limit and include most (ideally at least $70 \%$ ) of the ${ }^{39} \mathrm{Ar}$ extracted from the sample (e.g., Jourdan, 2012). They are, moreover, characterized by their internal statistics expressed through MSWD and $p$ values for plateau sections and isochrons (and are typically reported with $2 \sigma$ errors; that is, at the $\sim 95 \%$ confidence level, as is done in this work unless otherwise stated). Precise $\mathrm{Ar}-\mathrm{Ar}$ ages have been obtained for a number of impacts on Earth, such as 66.052 \pm 0.031 Ma for glassy microtektites from the $180 \mathrm{~km}$-diameter Chicxulub crater linked to the end-Cretaceous mass extinction (Renne et al., 2018). High-precision $\mathrm{Ar}-\mathrm{Ar}$ results for the Chicxulub microtektites at the $\mathrm{K} / \mathrm{T}$ boundary (more recently also known as the $\mathrm{K} / \mathrm{Pg}$ boundary) were recently used to calibrate the timing and duration of the contemporaneous reverse magnetic chron C29r (Sprain, 2017; Sprain et al., 2018). Similarly, Ries tektites (Fig. 3C) yielded a precise $\mathrm{Ar}-\mathrm{Ar}$ age of $14.808 \pm 0.038 \mathrm{Ma}$ (Schmieder et al., 2018a) that can also be used to (re-)calibrate the paleomagnetic and orbitally tuned astronomical timescale (Schmieder et al., 2018b). An increasingly robust intercalibration between the $\mathrm{U}-\mathrm{Pb}$ and $\mathrm{Ar}-\mathrm{Ar}$ geochronometers (e.g., Villeneuve et al., 2000; Ramezani et al., 2005; Renne et al., 2010, 2011) provides growing confidence that ages obtained when using both techniques are not only precise (i.e., with a small error) but also accurate (i.e., close to the "true" age) and can be directly compared and correlated.

As the $\mathrm{K}$ decay constants and ages for standard (monitor) minerals in ${ }^{40} \mathrm{Ar} /{ }^{39} \mathrm{Ar}$ geochronology have been continuously refined (e.g., Steiger and Jäger, 1977; Renne et al., 2010, 2011), modern Ar-Ar ages are today directly comparable with U-Pb ages (e.g., Renne et al., 2013, 2018; Sprain et al., 2015, 2018; Clyde et al., 2016). This, however, also means that "legacy" Ar-Ar ages published in the older literature are, in many cases, inaccurate and require recalculation (e.g., Jourdan et al., 2012; Schwarz et al., 2015; Mercer and Hodges, 2016; Schmieder et al., 2018a). Table 1 contains the most current $\mathrm{Ar}-\mathrm{Ar}$ ages that were (re-)calculated, where possible, using the revised $\mathrm{K}$ decay constants and monitor ages of Renne et al. (2010, 2011). For example, the original melt rock age of $64.98 \pm 0.05 \mathrm{Ma}(1 \sigma)$ for the Chicxulub impact crater, Mexico, published by Swisher et al. (1992) using the K decay constants of Steiger and Jäger (1977) and the Fish Canyon sanidine (FCs) standard with a then-reported age of $27.84 \mathrm{Ma}$, becomes $66.05 \pm$
$0.18 \mathrm{Ma}(2 \sigma)$ after the recalculation of individual step ages, plateau sections and ages, and weighted mean (average) ages $(n=3$ plateau ages; MSWD $=0.18 ; p=0.84)$ obtained from those results using Isoplot 4.15 (Ludwig, 2008) and the ArAR tool of Mercer and Hodges (2016). This recalculated age is within uncertainty indistinguishable from the more recent $\mathrm{U}-\mathrm{Pb}$ age of $66.021 \pm 0.081 \mathrm{Ma}$ for zircon crystals in ash layers around the $\mathrm{K} / \mathrm{T}$ boundary in the Denver Basin (Clyde et al., 2016). It is also equivalent to $\mathrm{Ar}-\mathrm{Ar}$ results of $66.038 \pm 0.049 \mathrm{Ma}$ for glassy microtektites found at the K/T boundary in Beloc, Haiti (Renne et al., 2013; Sprain et al., 2015), an age of 66.051 $\pm 0.031 \mathrm{Ma}$ for similar microtektites at a K/T section exposed on Gorgonilla Island off the coast of Colombia (Renne et al., 2018), and an age of 66.052 \pm $0.043 \mathrm{Ma}$ for tephra in the "Iridium $\mathrm{Z}$ coal" layer $\sim 1 \mathrm{~cm}$ above the iridium anomaly of the $\mathrm{K} / \mathrm{T}$ boundary interval (Renne et al., 2013; Sprain et al., 2018). The $\sim 24 \mathrm{~km}-$ diameter Boltysh impact structure in Ukraine, another endCretaceous impact structure (Kelley and Gurov, 2002), has a recalculated age of $65.80 \pm 0.67 \mathrm{Ma}$ that is, within a somewhat larger error envelope, identical to the age of the Chicxulub impact (Jourdan, 2012). However, from the identification of distal Chicxulub ejecta in the basal lake sediments of the Boltysh crater, we know that this impact predates Chicxulub by a few thousand years (Jolley et al., 2010).

Likewise, through recalculation, the age of the $\sim 35 \mathrm{~km}-$ diameter Manson impact structure, Iowa (decades ago still a contender for the K/T boundary impact site), also sees a notable shift from $74.1 \pm 0.1$ Ma (Izett et al., 1998) to an older recommended age of $75.9 \pm 0.1 \mathrm{Ma}$ (Table 1 ). The $\sim 100 \mathrm{~km}$-diameter Popigai impact structure in Russia, with a previously recommended $\mathrm{Ar}-\mathrm{Ar}$ age of $35.7 \pm 0.2 \mathrm{Ma}$ (Bottomley et al., 1997) has, after a reinterpretation of the original $\mathrm{Ar}-\mathrm{Ar}$ results, a more conservative recalculated age of $36.63 \pm 0.92 \mathrm{Ma}$, which accounts for the spread of $\sim 1$ Myr between four plateau ages, not all of which overlap ( $n=4$ plateau ages; MSWD $=7.6 ; p=0.000$ ) (see also Jourdan et al., 2009). From this recalculation, a time gap of at least $\sim 0.5 \mathrm{Myr}$ (and up to $\sim 3 \mathrm{Myr}$ ) seems to occur between Popigai and the somewhat younger $(34.86 \pm 0.32$ Ma) $\sim 40$ to $45 \mathrm{~km}$-diameter Chesapeake impact structure (a.k.a. Chesapeake Bay; final collapsed diameter $\sim 85 \mathrm{~km}$ ) on the East coast of the United States (Assis Fernandes et al., 2019). This asteroid "one-two punch" is in agreement with the occurrence of two relatively closely spaced, but separate, distal ejecta layers in the Upper Eocene (Glass et al., 1985; Koeberl, 2009) (Table 2), known as the older clinopyroxene layer geochemically linked to the Popigai impact (Whitehead et al., 2000) and the younger North American (micro-)tektites linked to the Chesapeake impact (Deutsch and Koeberl, 2006).

In a few cases, recalculation of the original Ar-Ar results was omitted due to potentially unreliable standard ages used in the original geochronologic analysis. This, for example, applied to ages obtained using the B4M muscovite standard, which was commonly used in geochronology laboratories in the 1980s (e.g., for the Haughton impact structure, Canada) (Jessberger, 1988) and later (for the Ilyinets impact structure, Ukraine) (Pesonen et al., 2004). The B4M standard was recently shown to be quite heterogeneous in composition and age between finer- and corser-grained domains of the 


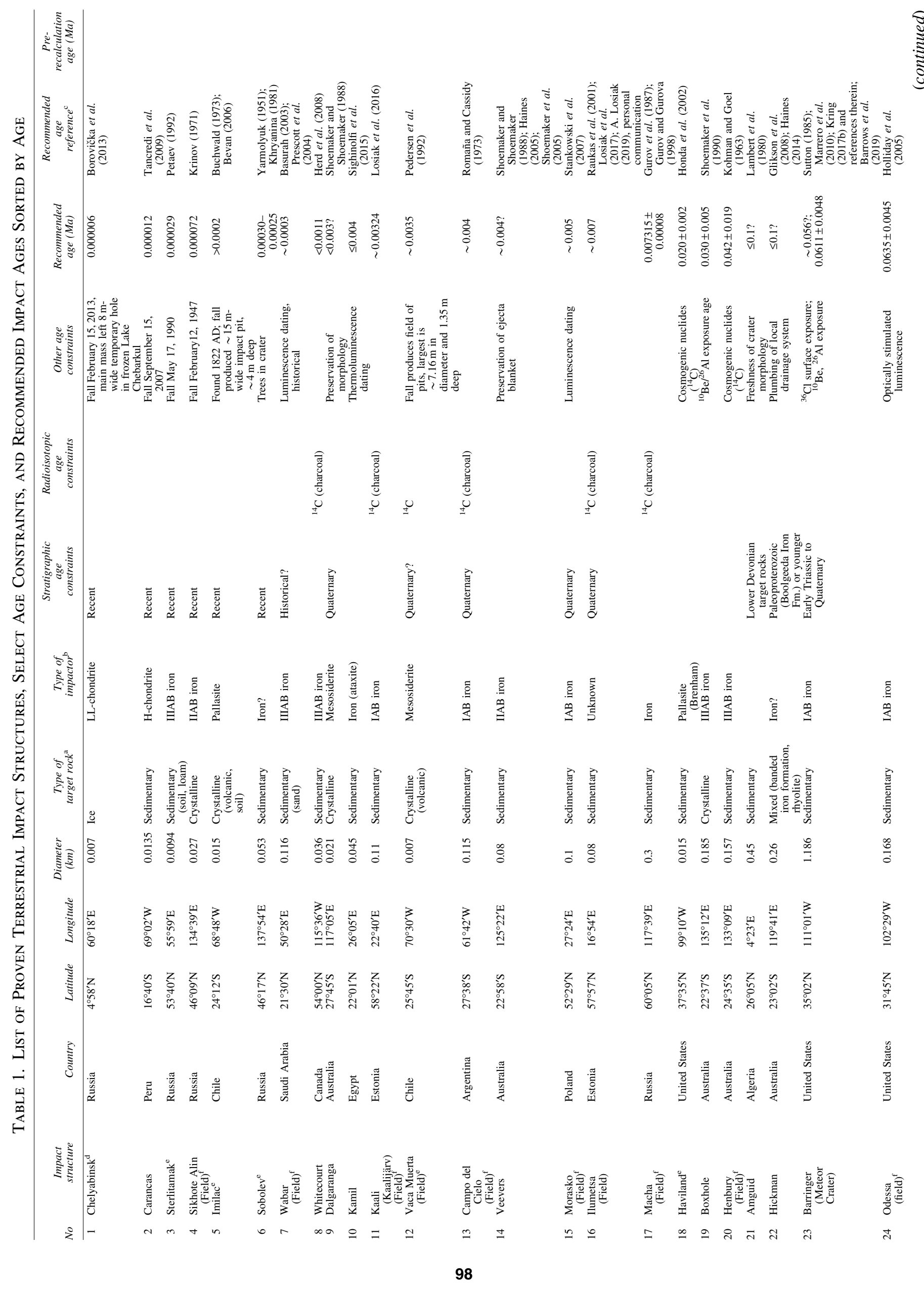




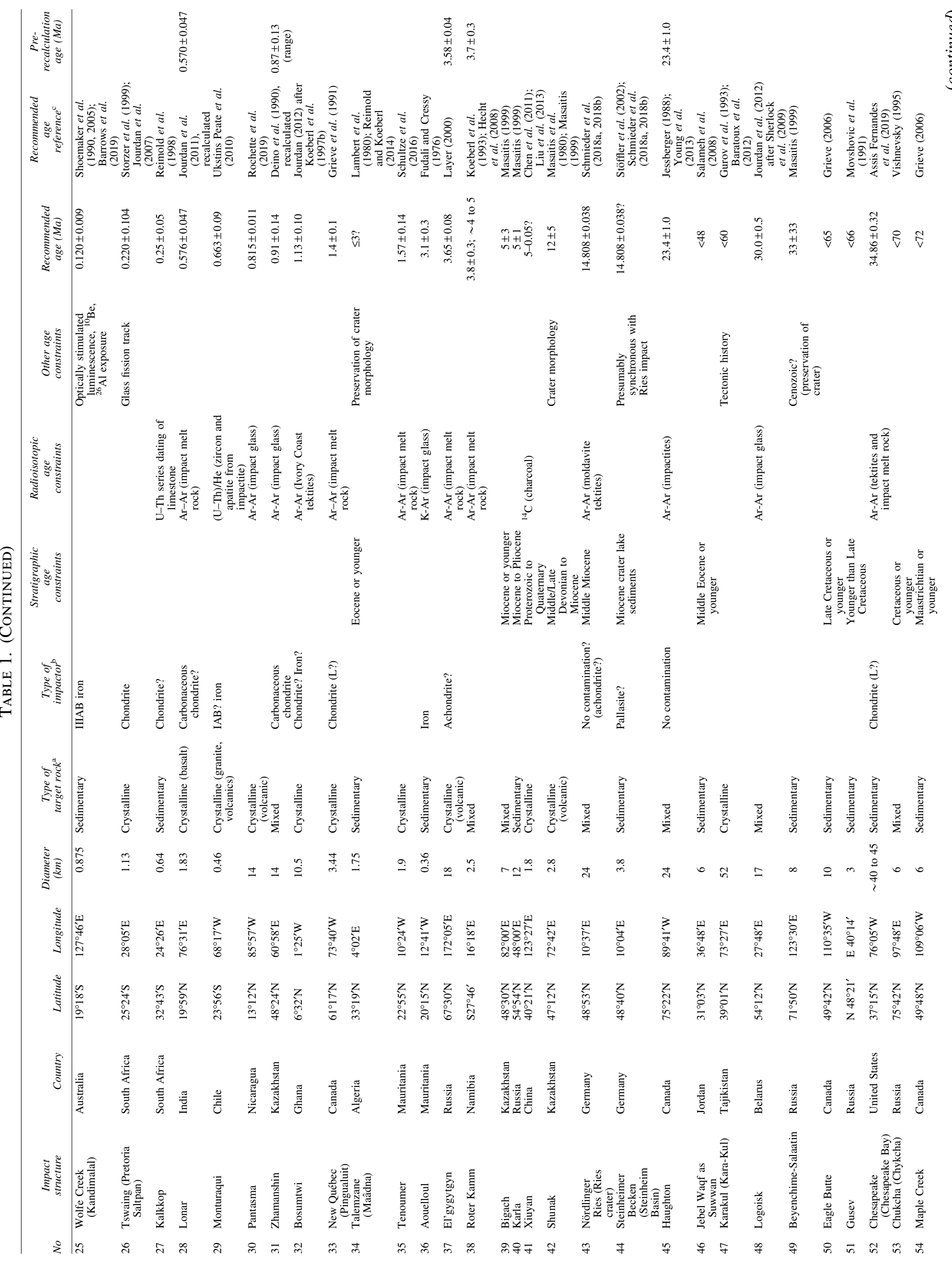




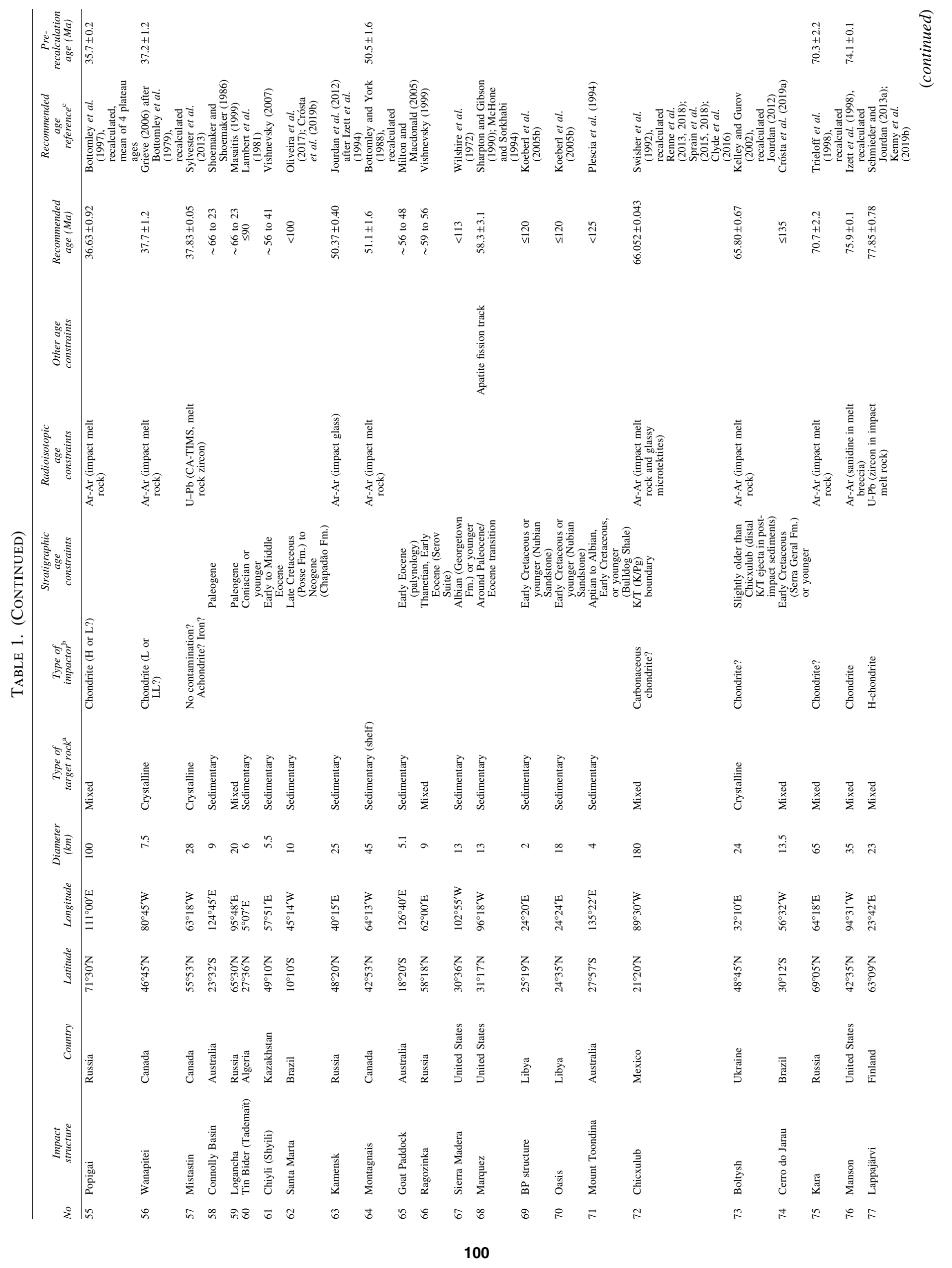




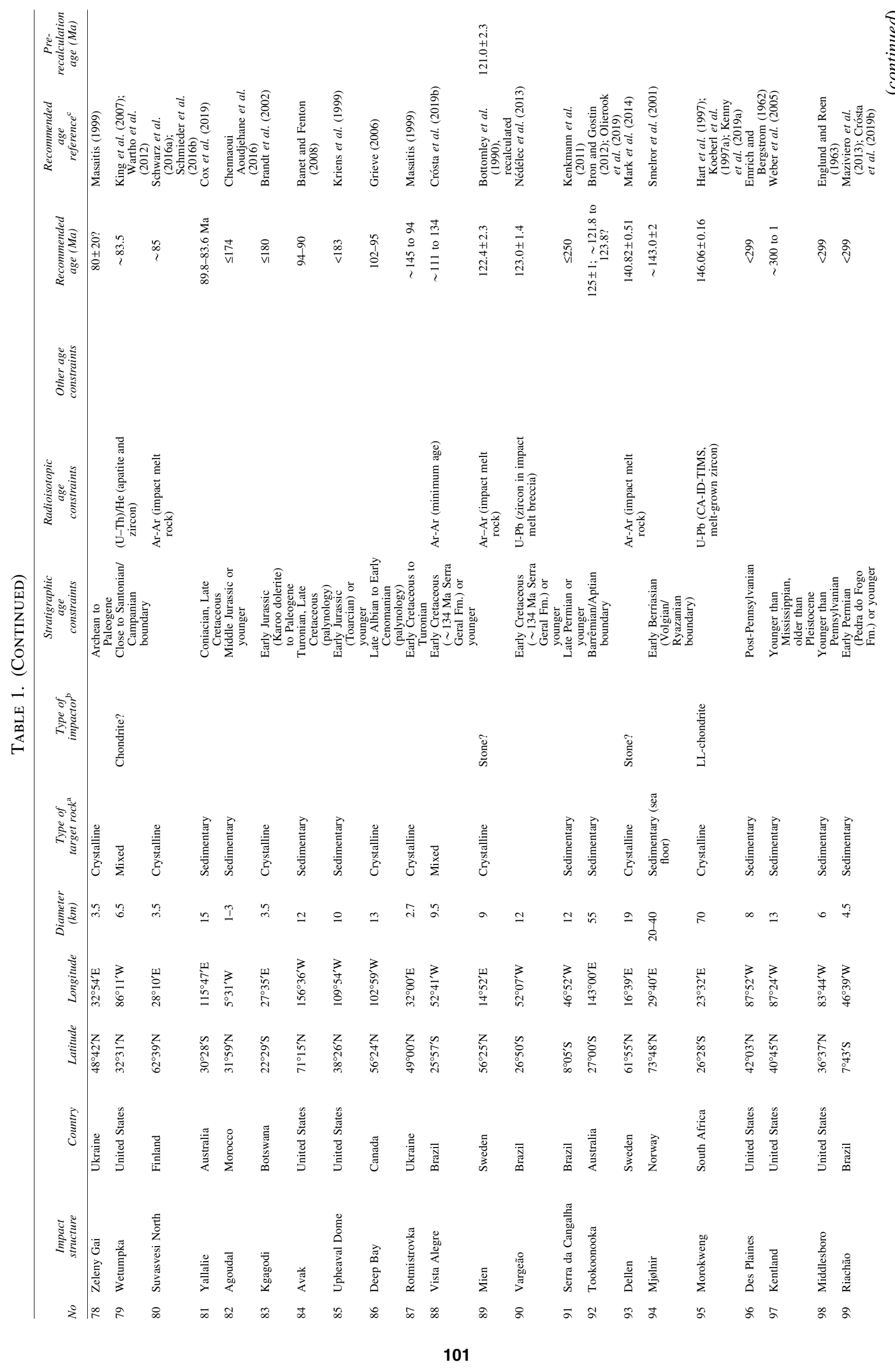




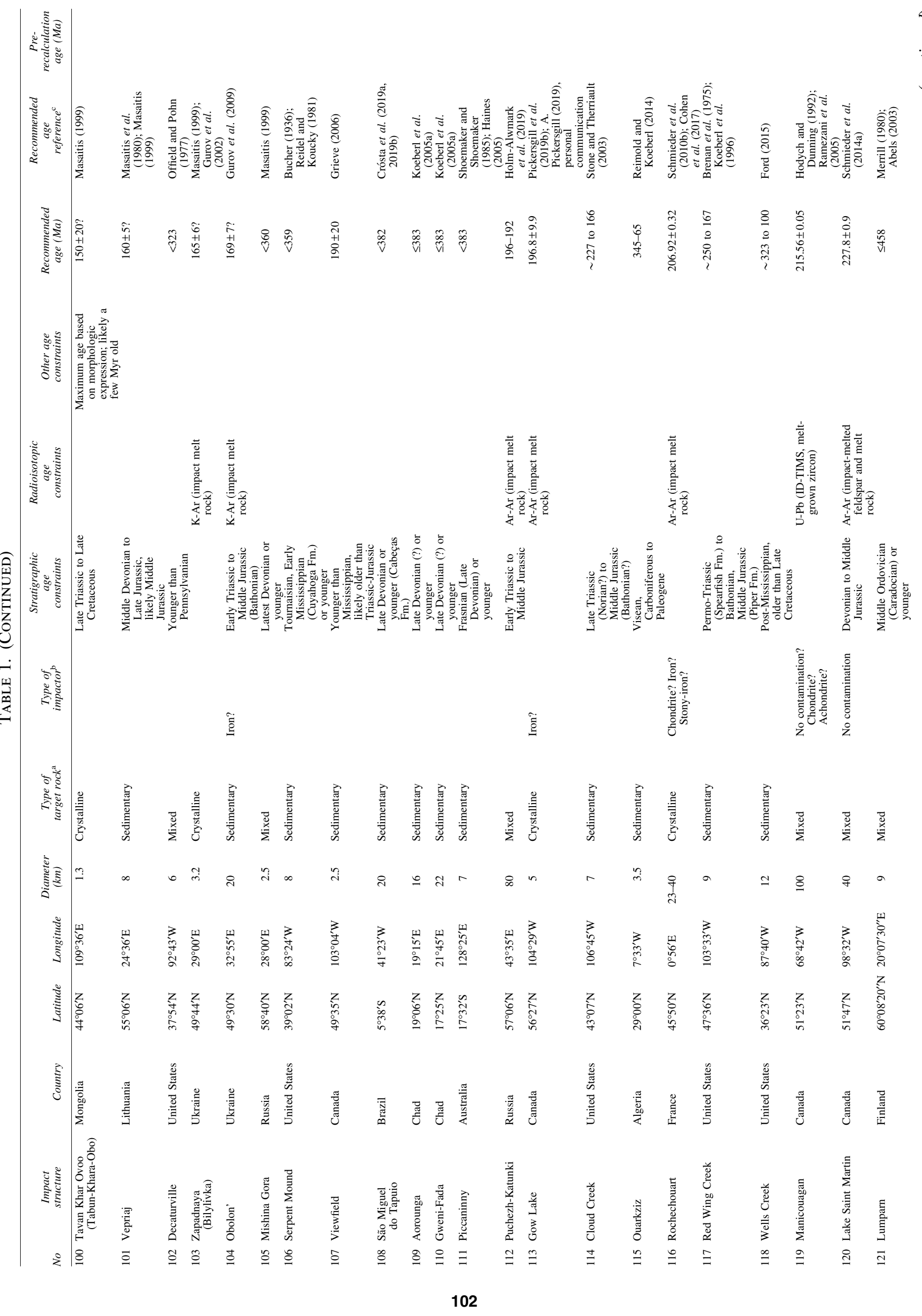









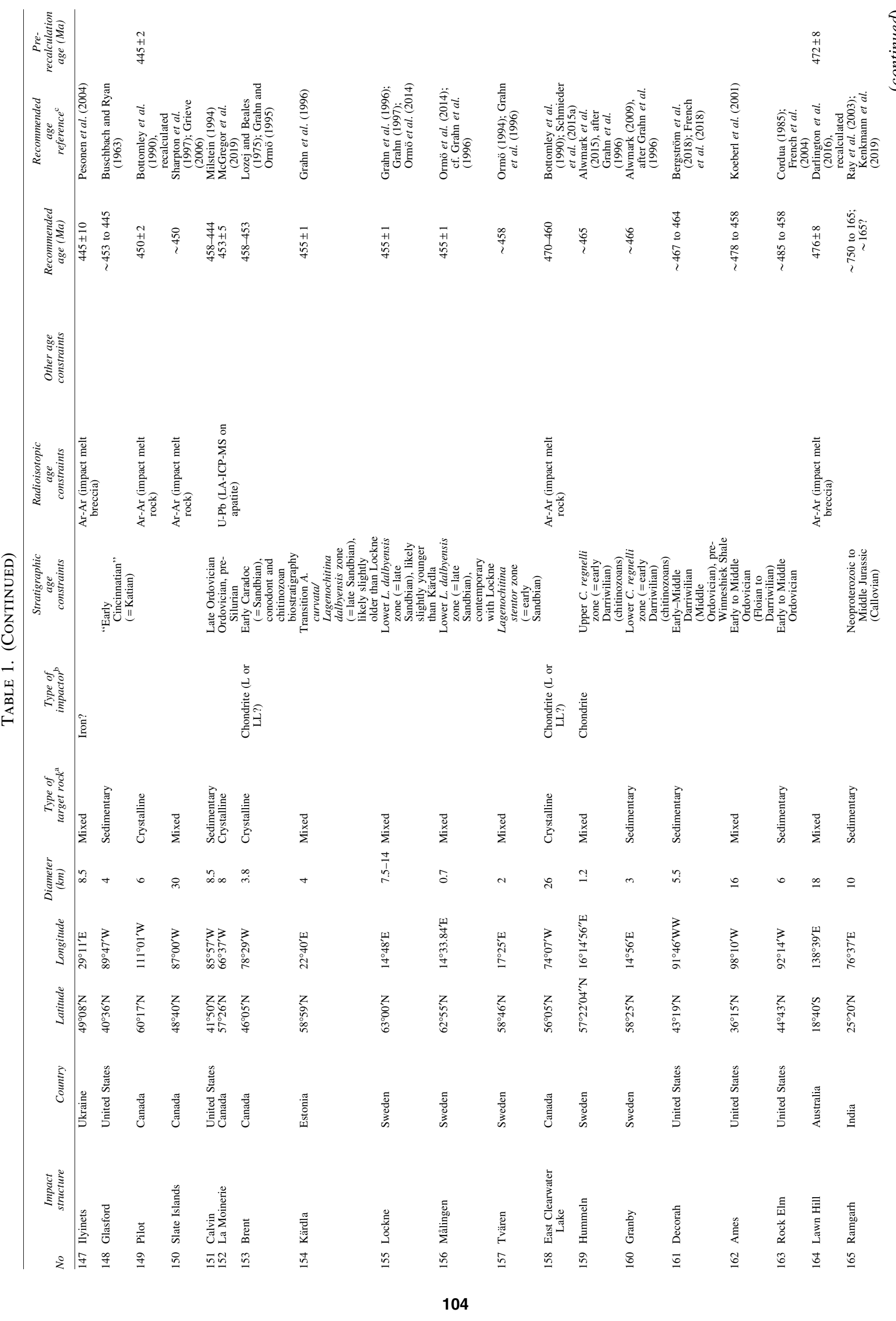









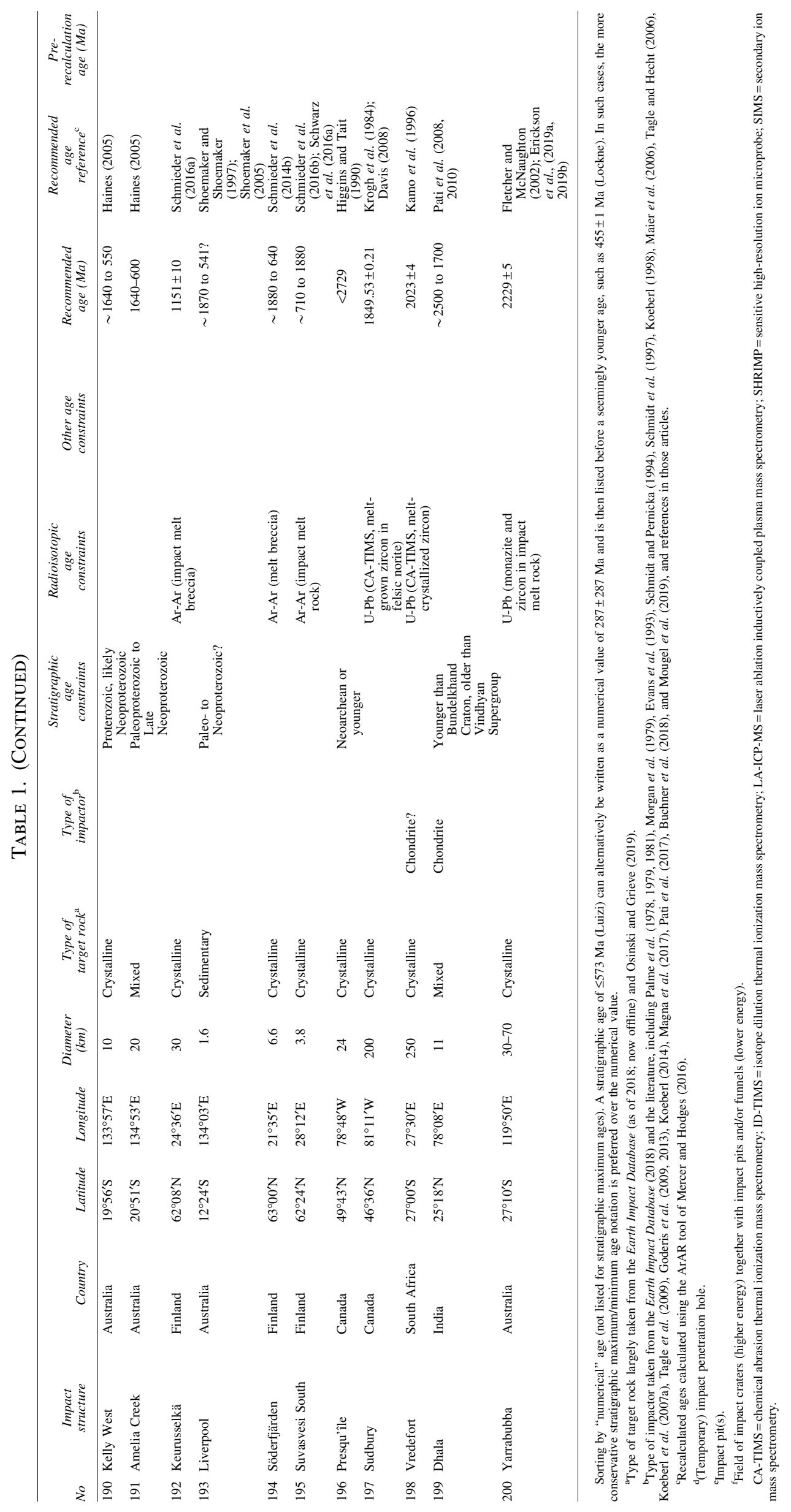




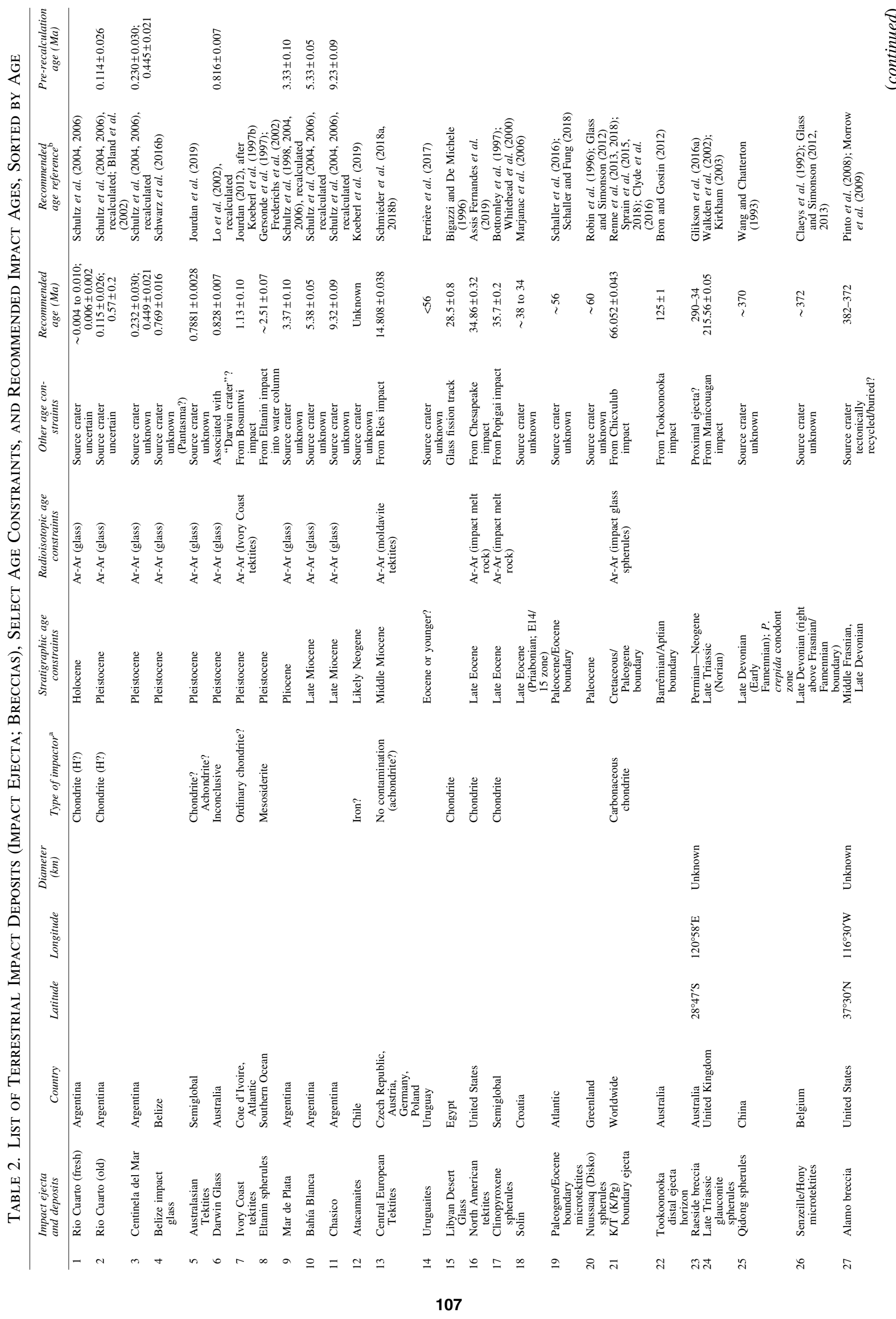




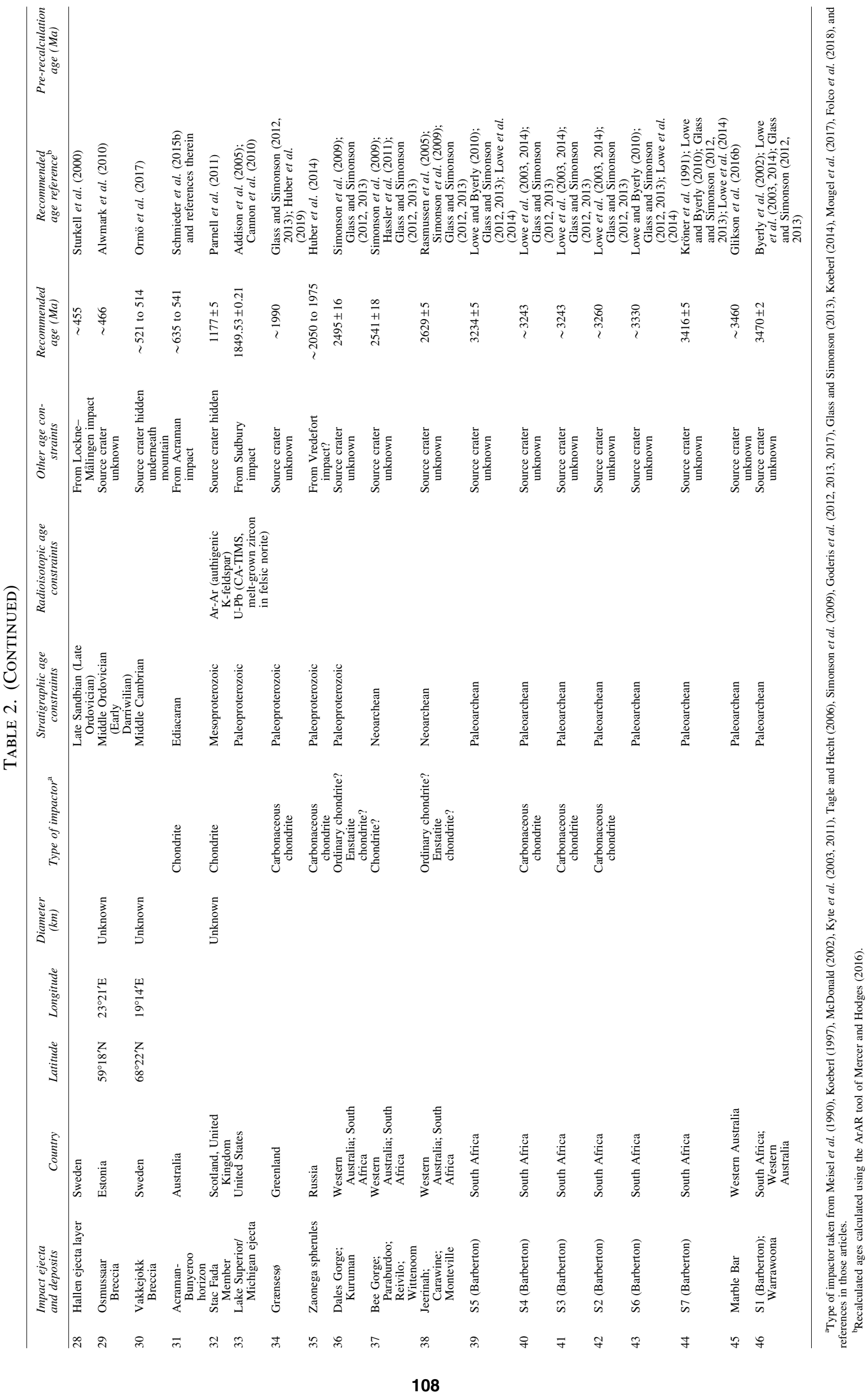


muscovite and is, therefore, not recommended as a standard in modern Ar-Ar geochronology (Heri et al., 2014). Finally, some impact structures, predominantly those in Russia and Ukraine, have only K-Ar ages (e.g., Val'ter et al., 1981; Gurov et al., 2009). Because any possible disturbance of the isotopic system (e.g., alteration or contamination with older material as outlined above) cannot be identified and quantified, $\mathrm{K}-\mathrm{Ar}$ age values should be treated as "ballpark" numbers until more robust Ar-Ar results are available.

\section{3. $R b-S r,(U-T h) / H e$, and ${ }^{14} \mathrm{C}$ ages}

The $\mathrm{Rb}-\mathrm{Sr}$ method has been applied to impact melt lithologies and mineral separates from a number of terrestrial impact structures (e.g., Reimold et al., 1981; Deutsch et al., 1992). However, $\mathrm{Rb}-\mathrm{Sr}$ ages are notoriously unreliable due to the high mobility of $\mathrm{Rb}$ and $\mathrm{Sr}$ and, consequently, the susceptibility of the $\mathrm{Rb}-\mathrm{Sr}$ isotopic system to alteration (e.g., Jourdan et al., 2009; Nebel et al., 2011; Schmieder et al., 2015a). Today, all of the older $\mathrm{Rb}-\mathrm{Sr}$ ages for terrestrial impact structures (e.g., Reimold et al., 1981) have been superseded by more robust $\mathrm{U}-\mathrm{Pb}$ and/or $\mathrm{Ar}-\mathrm{Ar}$ ages and, therefore, none of the original $\mathrm{Rb}-\mathrm{Sr}$ results is recommended as best-estimate ages in this summary (Table 1).

The low-temperature (U-Th)/He geothermochronometer can monitor the cooling of impact lithologies to temperatures below approximately $200-180^{\circ} \mathrm{C}$ using zircon and $\sim 110-40^{\circ} \mathrm{C}$ using the less He-retentive mineral apatite (e.g., Stockli et al., 2000; Farley and Stockli, 2002; Farley, 2002; Reiners et al., 2004; Reiners, 2005). While (U-Th)/ He analyses of uplifted basement rocks at the large Manicouagan impact structure resulted in ages younger than the impact age due to slow cooling and postimpact He loss (van Soest et al., 2011; Biren et al., 2014), (U-Th)/He age determinations for other terrestrial impact structures and distal ejecta deposits yielded ages that are, within error, consistent with U-Pb and Ar-Ar ages (Young et al., 2013; Biren et al., 2019) and precise stratigraphic ages (Wartho et al., 2012). In the absence of more robust stratigraphic and isotopic age constraints, a (U-Th)/He age of $663 \pm 90$ ka currently represents the most reasonable estimate for the age of the $\sim 350$ m-diameter Monturaqui impact crater in the Chilean Andes (Ukstins Peate et al., 2010).

Finally, the ${ }^{14} \mathrm{C}$ (radiocarbon) method has occasionally been applied to charcoal and other types of organic material found at geologically young impact craters, such as the Xiuyan crater in China (>50 ka) (Liu et al., 2013) and the Kaali and Ilumetsa impact crater fields in Estonia (Losiak et al., 2016, 2017, 2019). Because of the short half-life of ${ }^{14} \mathrm{C}$ of $\sim 5730$ years, the method fails to determine ages older than roughly 50,000 years (Hughen et al., 2004; Muscheler et al., 2014).

\subsection{Other ages}

Impact ages obtained via different methods, such as fission track analysis (on zircon, apatite, or glass) (e.g., Bigazzi and De Michele, 1996), cosmogenic nuclides and exposure ages (e.g., Marrero et al., 2010; Barrows et al., 2019), luminescence (e.g., Prescott et al., 2004), or paleomagnetic methods (e.g., Pesonen et al., 1999; Lepaulard et al., 2019), were selected as best-estimate ages, provided they agree with the local geologic constraints. Recent re- views of fission track analysis and its application in the Earth sciences are provided by Malusà and Fitzgerald (2019) and articles therein. This technique, based on the identification of damage trails in crystals and glasses induced by the spontaneous fission of ${ }^{238} \mathrm{U}$ in the sample and their density (e.g., Kohn et al., 2019), has been applied to impact lithologies ever since their discovery (e.g., Gentner et al., 1967, 1969; Koeberl et al., 1993; McHone and Sorkhabi, 1994; Weber et al., 2005). In the case of the 1.13 km-diameter Tswaing impact crater in South Africa, a fission track age of $220 \pm 104 \mathrm{ka}$ for impact glass (Storzer et al., 1999) is preferred over a very poorly constrained stratigraphic age $(<2.05 \mathrm{Ga})$ and $\mathrm{Ar}-\mathrm{Ar}$ results that are disturbed toward more ancient apparent ages due to the presence of inherited ${ }^{40} \mathrm{Ar}^{*}$ sourced from the Paleoproterozoic granitic target rock (Jourdan et al., 2007). Sometimes, these geochronologic techniques provide the only age constraints for an impact structure other than the (maximum) stratigraphic age.

\section{Result: A List of Recommended Ages for Terrestrial Impact Structures and Deposits}

Significant work on the terrestrial impact structures has produced a large number of ages of different type and quality (e.g., for the Nördlinger Ries in Germany) (Buchner et al., 2010a, 2010b, 2013 and references therein; Schmieder et al., 2018a, 2018b). In such cases, the most precise and accurate ages obtained by using modern isotopic techniques, in line with geologic and stratigraphic constraints, were carefully chosen as the recommended best-estimate impact age. Stratigraphic constraints were calibrated using the latest International Chronostratigraphic Chart (ICS; updated, v2018/08) (Cohen et al., 2013). It is important to keep in mind that stratigraphic ages in the ICS may (slightly) change in the future as those ages are refined.

The recommended terrestrial impact ages $(n=200)$ are listed in Table 1, and ages for impact deposits (distal and proximal ejecta; $n=46$ ) are listed in Table 2. Both tables are sorted by age, with the youngest impact structures and deposits on top and the oldest ones at the bottom. Twenty impact structures have either stratigraphic or isotopic ages with relative errors $\leq 1 \%$ (e.g., Chicxulub and the Ries); 36 have errors $\leq 2 \%$. All terrestrial impact ages are, in addition, plotted in histograms in Fig. 4. They can be used to:

(1) reconstruct and quantify the impact (mass) flux in the inner Solar System and, in particular, the EarthMoon system through geologic time, thereby assessing Earth's impact rate (e.g., Grieve and Dence, 1979; Montanari et al., 1998; Grieve, 2001a, 2001b; Bland, 2005; Meier and Holm-Alwmark, 2017; Mazrouei et al., 2019);

(2) utilize impact ejecta as event markers in the (bio-)stratigraphic record and to refine magnetostratigraphy, for example, around the K/T boundary (e.g., Sprain et al., 2015, 2018) and in the Neogene stratigraphic record (e.g., Schmieder et al., 2018a, 2018b);

(3) test models of synchronous double or multiple impacts in the terrestrial record, such as that proposed for the apparent East and West Clearwater Lake impact 


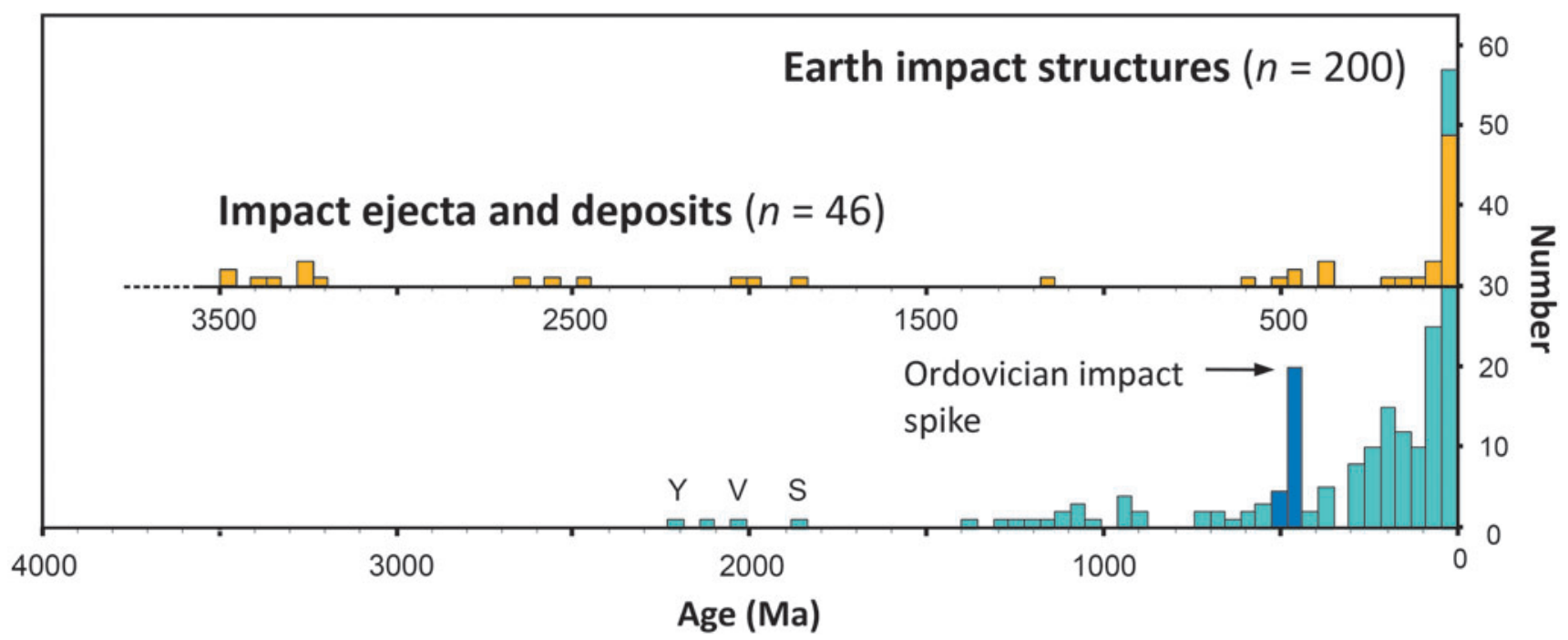

FIG. 4. Histogram showing the age distribution of terrestrial impact structures (blue) and ejecta deposits (orange). Ejecta layers that presumably have the same age and occur at more than one locality (e.g., the 3470 Ma Paleoarchean S1 Barberton and Warrawoona spherule layer identified in South Africa and Western Australia, respectively) are shown as one deposit. Ages are average ages (e.g., 2100 $400 \mathrm{Ma}$ for Dhala, India, shows as an age at 2100 Ma). Note the distinct Ordovician impact spike around $\sim 470$ to $450 \mathrm{Ma}$ (darker blue). Note this diagram does not distinguish between larger and smaller impacts. S, Sudbury (Krogh et al., 1984; Davis, 2008); V, Vredefort (Kamo et al., 1996); Y, Yarrabubba (Erickson et al., 2019a, 2019b). Compare Table 1 with ages for impact structures and Table 2 with ages for ejecta deposits.

crater doublet in Québec, Canada (e.g., Dence et al., 1965; cf. Schmieder et al., 2015a), and the postulated Late Triassic terrestrial impact crater chain (e.g., Spray et al., 1998; cf. Schmieder et al., 2010b, 2014a);

(4) assess the potential link between large impacts and mass extinction and diversification events in the biosphere, exemplified most dramatically by the Chicxulub impact at the K/T boundary (e.g., Alvarez et al., 1980; Rampino, 1999; Grey et al., 2003; Schmitz et al., 2008; Schulte et al., 2010; Racki, 2012; DePalma et al., 2019);

and

(5) constrain the duration of melt sheet crystallization in large impact craters (e.g., Davis, 2008; Kenny et al., 2019a) and the lifetime of hydrothermal systems in cooling impact craters (e.g., Ames et al., 1998; Abramov and Kring, 2004, 2007; Schmieder and Jourdan, 2013a, 2013b; Pickersgill et al., 2019a; Kenny et al., 2019b), which may have served as potential habitats for microbial life on the early Earth and possibly also Mars (e.g., Kring, 2000; Rathbun and Squyres, 2002; Cockell et al., 2003; Osinski et al., 2013; Rummel et al., 2014).

\section{Discussion}

\subsection{Considerations on the terrestrial impact flux from the age distribution}

With a representative set of precise and accurate isotopic ages for terrestrial impacts, as well as stratigraphic ages within their generally larger envelope of uncertainty (Tables 1 and 2), one can examine and re-evaluate the potential temporal connection between impact events on Earth themselves and the overall terrestrial impact cratering record (e.g., Grieve and Dence, 1979; Grieve and Robertson, 1979; Grieve, 1987, 1991, 2001a, 2001b; Grieve and Pesonen, 1996).

As more impact structures are discovered and their ages determined and refined, a population of the Phanerozoic impact structures and deposits stands out: those with Ordovician ages. The Ordovician period spans the time between $\sim 485$ and $\sim 443 \mathrm{Ma}$ (Cohen et al., 2013). At present, 22 of the currently known 200 impact structures on Earth, that is, more than $10 \%$, have proven or very likely Ordovician ages, creating a distinct age spike in the terrestrial impact cratering record. A representative histogram is shown in Fig. 4. Recent additions to the list of (very likely) Ordovician impacts, based on new $\mathrm{U}-\mathrm{Pb}$ and $\mathrm{Ar}-\mathrm{Ar}$ geochronologic results, include, for example, the $54 \mathrm{~km}$-diameter Charlevoix impact structure (453-430 Ma via LA-ICP-MS U-Pb on zircon in impact melt rock) (Schmieder et al., 2019), the $50 \mathrm{~km}$-diameter Carswell impact structure (Alwmark et al., 2017), and the $8 \mathrm{~km}$-diameter La Moinerie impact structure (McGregor et al., 2019), all three located in Canada; as well as the $18 \mathrm{~km}$-diameter Lawn Hill impact structure in Australia (Darlington et al., 2016). Those impact structures, six in the United States, nine in Canada, five in Sweden, and one in Estonia, Ukraine, and Australia, respectively, were produced over several million years (e.g., Grahn et al., 1996; Alwmark et al., 2010). In addition, a large number of fossil meteorites found in Ordovician limestone in Sweden (e.g., Schmitz et al., 1996, 2001) and the impact-produced Osmussaar Breccia in Estonia (Alwmark et al., 2010) testify to a period of enhanced bombardment of Earth by asteroids at that time. Analysis of the fossil meteorites and impact breccias suggests that most of the Ordovician impacts are linked to the collisional breakup of the L-chondrite parent asteroid in space some 470 Myr ago (e.g., Ar-Ar results of Bogard et al., 1976, 1995; Korochantseva et al., 2007; 
Swindle et al., 2014), which then sent large masses of partially shock-melted stony meteorites into Earth-crossing orbits. Extraterrestrial chromite grains extracted from resurge deposits of the Lockne impact structure and the Osmussaar Breccia indicated an L-chondritic source (Alwmark and Schmitz, 2007; Alwmark et al., 2010). Geochemical analysis of impact melt rock from the East Clearwater Lake impact structure in Canada also suggested an ordinary (possibly L-) chondritic impactor (Palme et al., 1979; McDonald, 2002; Daly et al., 2018). However, the Ordovician bombardment of Earth was one of numerous but predominantly relatively small asteroids.

Apparent "clusters" of impacts, that is, two or more impact events with overlapping or nearly overlapping ages, also seem to occur in geologic times other than the Ordovician. For example, at least four impact structures, Popigai in Russia (Bottomley et al., 1997, Ar-Ar age recalculated), Chesapeake in the United States (Assis Fernandes et al., 2019), and Wanapitei (Bottomley et al., 1979, recalculated) and Mistastin in Canada (Sylvester et al., 2013), have isotopic ages that all fall in the time range between $\sim 38$ and $\sim 35 \mathrm{Ma}$ in the Late Eocene (Cohen et al., 2013). However, not all of their (recalculated) ages overlap $(n=4$ impact crater ages; $\mathrm{MSWD}=114 ; p=0.000$ ). From the age distribution (and the associated uncertainty) alone, the formation of four larger impact structures within a few million years may appear like the usual background production when considering the effective impact crater distribution and cratering rate (Wanapitei-sized impact craters are statistically produced every $\sim 60,000$ years; Mistastin-sized craters every $\sim 600,000$ years; Chesapeake-sized craters every $\sim 4.5 \mathrm{Myr}$; and Popigai-sized impact craters every 26 Myr) (e.g., Grieve and Shoemaker, 1994; French, 1998). However, a distinct $\sim 2.5 \mathrm{Myr}-$ long spike in extraterrestrial ${ }^{3} \mathrm{He}$ in pelagic limestone (Farley et al., 1998), in combination with a strong enrichment in extraterrestrial chromite grains in Upper Eocene sediments of the Global Boundary Stratotype Section and Point (GSSP) for the Eocene-Oligocene at Massignano, Italy, (Schmitz et al., 2015; Boschi et al., 2017), argues for a Late Eocene asteroid (or comet) shower, thereby potentially producing a distinct impact cluster. One mechanism that can explain the formation of clusters in the terrestrial impact crater record is one or more impacts in space causing the breakup of large asteroids into families of asteroids, members of which can then be delivered to the Earth (e.g., Zappalà et al., 1998; Nesvorný et al., 2002, 2006; Farley et al., 2006; Bottke et al., 2007; Claeys and Goderis, 2007; Schmitz et al., 2008). Trace element analysis of impactites suggested that the Popigai and Wanapitei impact structures both had L-chondritic impactors (Masaitis and Raikhlin, 1986; Tagle and Claeys, 2004, 2005; Tagle and Hecht, 2006; Tagle et al., 2006), although Kyte et al. (2011) argued that the Popigai-derived Upper Eocene clinopyroxene spherule layer may be linked to the impact of an H-chondrite. The nature of the impactor that produced the Chesapeake crater is, at this point, still somewhat uncertain (McDonald et al., 2009; Goderis et al., 2010). The geochemical and oxygen isotopic analysis of extraterrestrial chromite grains found in Upper Eocene sediments at Massignano indicates an $\mathrm{H}$ chondritic source for the Popigai impact and an L-chondritic source for the somewhat younger Chesapeake impact (Schmitz et al., 2015; Boschi et al., 2017).
In addition to seemingly clustered impacts, the recognition of an apparent periodic pattern in the timing of impact events has caused a debate that started in the mid-1980s and still continues today. Following Raup and Sepkoski (1984), who found that mass extinctions in the Phanerozoic seem to have a periodic pattern potentially caused by extraterrestrial forces (such as periodic cometary showers), other researchers also recognized through time-series analysis that large impacts occurred in a similar repetitive pattern of predominantly $\sim 26$ and $\sim 30$ Myr intervals over the past $\sim 250$ Myr and may, therefore, be causally linked (e.g., Alvarez and Muller, 1984; Davis et al., 1984; Rampino and Stothers, 1984; Torbett and Smoluchowski, 1984; Muller, 1985; Rampino and Haggerty, 1996; Rampino and Caldeira, 2015, 2017). However, one should keep in mind that those periodicity models were based on the impact crater ages available in the 1980s and 90s, and since then, other workers have called the proposed periodicity into question (e.g., Grieve et al., 1988; Heisler and Tremaine, 1989; Baksi, 1990; Weissman, 1990; Yabushita, 1996; MacLeod, 1998; Montanari et al., 1998; Bailer-Jones, 2011), some of them noting that the apparent periodicity may, in part, be an artificial effect due to the rounding of imprecise impact ages to integer values, often in multiples of 5 or $10 \mathrm{Ma}$ (e.g., Jetsu and Pelt, 2000; Grieve and Kring, 2007). More recently, Meier and Holm-Alwmark (2017) demonstrated that the apparent periodic pattern in Earth's impact events, at least those filtered for reasonably precise and accurate age constraints (compare Baksi, 1990), may be related to clusters of impacts with similar ages that seem to be the main carriers of the periodic signal. Based on refined statistics, they argued that there is currently no evidence for periodicity in the terrestrial impact record when up-to-date impact crater ages are used as input parameters. Ages presented in Tables 1 and 2 of this work aim to help resolve such issues and debates.

In the context of seemingly periodic impacts and extinction events (Raup and Sepkoski, 1984) and the "kill curve" of Raup (1990), we also refer to the role of impacts in Earth's biosphere (Section 4.4).

Precise and accurate impact ages, moreover, help constrain the preserved terrestrial crater size-frequency distribution and, by inference, estimate the impact cratering rate in the Earth-Moon system in the past. Figure 5 shows the cumulative number of Earth's impact structures of variable size with reasonably well-constrained ages $( \pm 10$ Ma error) for the entire Earth, including very small impact craters (and pits) $\sim 7$ to $500 \mathrm{~m}$ in diameter (which are usually not plotted because they are preferentially removed from Earth's record by erosion; e.g., Grieve and Dence, 1979; Hughes, 2000). Because the terrestrial impact record is incomplete for several reasons outlined earlier (e.g., Johnson and Bowling, 2014; Hergarten and Kenkmann, 2015) (Fig. 1), the lunar impact record and its crater size-frequency distribution are commonly used as a proxy for the impact crater production rate on Earth (e.g., Neukum and Ivanov, 1994; Neukum et al., 2001; Werner et al., 2002; Ivanov et al., 2003). Additional constraints come from the size-frequency distribution of near-Earth asteroids (e.g., Shoemaker et al., 1979; Durda et al., 1998; Morbidelli, 1999; Bottke et al., 2000; Werner et al., 2002; Stuart and Binzel, 2004; Michel and Morbidelli, 2007; Le Feuvre and Wieczorek, 2011; Johnson 

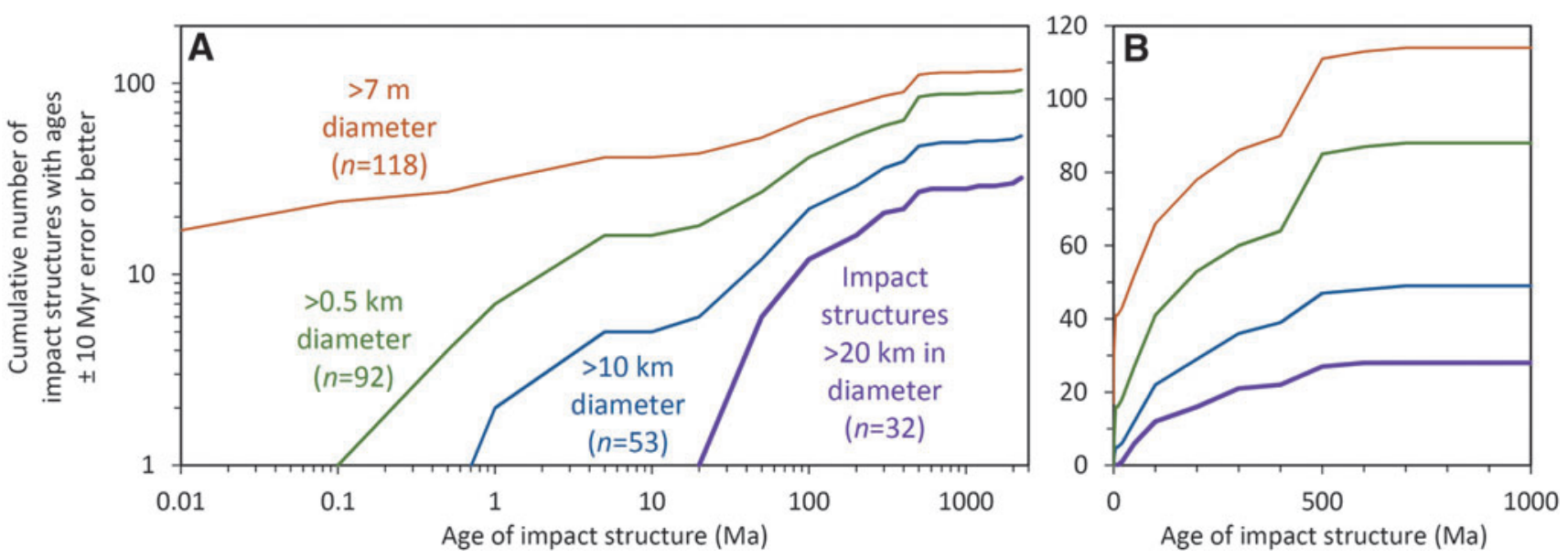

FIG. 5. Cumulative number of impact structures with more or less well-established ages ( $\pm 10 \mathrm{Ma}$ in error) versus time for the entire Earth and including different crater size populations (compare, e.g., Grieve, 1984; Mazrouei et al., 2019). (A) Log-log plot over >2 Gyr; (B) linear plot for the past 1 Gyr [same color scheme as in (A)].

and Bowling, 2014; Wheeler and Mathias, 2019), the population of Earth-crossing comets, the Sun's position in the galactic plane (e.g., Shoemaker, 1998b; Ye, 2018), as well as the distribution of extraterrestrial ${ }^{3} \mathrm{He}$ (Farley, 1995, 1998, 2001), platinum-group metals (Peucker-Ehrenbrink, 2001), and fossil meteorites and extraterrestrial chromite grains (e.g., Schmitz et al., 1996, 2001, 2015; Heck et al., 2004; Alwmark and Schmitz, 2009; Schmitz, 2013) in marine sediments. While some authors proposed that the impact flux in the Earth-Moon system has continuously declined over the past $3 \mathrm{Gyr}$ (Minton and Malhotra, 2010), others suggested that the impact flux has remained more or less stable over the last 2 Gyr (e.g., Neukum and Ivanov, 1994; Hörz, 2000; Hughes, 2000). Part of this debate is whether the Earth has seen a significant increase of impacts, particularly those producing craters $>20 \mathrm{~km}$ in diameter, over the last few hundred $\mathrm{Myr}$ - perhaps by a factor of two or three (e.g., Grieve, 1984; McEwen et al., 1997; Shoemaker, 1998a, 1998b; Hughes, 2000; Bland, 2005; cf. Grier et al., 2001). More recently, Mazrouei et al. (2019) suggested that the terrestrial impact flux experienced an increase by a factor of 2.6 some $290 \mathrm{Myr}$ ago. It is beyond the scope of this geochronology-focused article to assess Earth's effective impact cratering rate, but while Bland (2005) provides a useful summary and discussion, the list of recommended impact ages (Tables 1 and 2) may help place additional constraints on the Proterozoic $(2.5 \mathrm{Ga}$ to $\sim 541 \mathrm{Ma})$ and Phanerozoic ( $541 \mathrm{Ma}$ until present) terrestrial impact crater production.

\subsection{Impact-delivered extraterrestrial mass accreted on Earth over time}

While the distribution of impact ages in the geologic time line suggests that the Earth was hit by asteroids (and/or comets) more frequently during, for example, the Ordovician compared with other periods of time, it is important to note that this temporal distribution is biased by various factors. First, the terrestrial impact cratering record is, with currently 200 impact structures recognized on Earth, very limited and, therefore, not representative of a planetary pro- duction record (e.g., Grieve and Dence, 1979; Johnson and Bowling, 2014). Because the majority of impactors hit the seafloor (particularly during geologic times with supercontinents) and the oceanic crust has been tectonically recycled in multiple Wilson cycles over 2 Gyr (e.g., Scotese, 2001), most impact structures have been removed from Earth's surface (e.g., Johnson and Bowling, 2014; Hergarten and Kenkmann, 2015). With the exception of the $\sim 20$ to $40 \mathrm{~km}-$ diameter Jurassic-Cretaceous Mjølnir impact structure off the coast of Norway (Dypvik et al., 1996), the $\sim 45 \mathrm{~km}-$ diameter Eocene Montagnais impact structure on the Scotian Shelf of eastern Canada (Jansa et al., 1989), and evidence for the Pleistocene submarine Eltanin impact (Gersonde et al., 1997), no impact structures are currently known on the present-day seafloor. Second, some countries (e.g., the United States, Canada, Australia, and many European countries) have a longer tradition in impact crater research compared with others (e.g., China), which may cause an apparent preponderance of impacts in those countries and their respective geologic settings. Australia and Finland, for example, have a relatively high density of preserved Precambrian impact structures because much of their landmass consists of Archean and Proterozoic rocks that can preserve this old cratering record (Fig. 2). Third, impact ages can be more precisely determined stratigraphically in well-characterized sedimentary target settings similar to that at the Lockne crater, Sweden, than in others (e.g., Île Rouleau, Canada), an effect that probably contributes to the impact age spike in the Ordovician. Lastly, the impact age distribution shown in Fig. 4 does not take into account the actual magnitude of the impact events that occurred over time, which can be expressed by the mass of projectile material delivered to Earth during impact and the corresponding impact energy (half of the projectile mass times the impact velocity squared) (e.g., French, 1998).

An alternative and perhaps more informative way of representing the impact flux through geologic time is plotting the accreted impactor mass versus time (Fig. 6). By using equations modified after the work of Abramov et al. (2012) and well-established impact crater scaling laws (e.g., Grieve et al., 1981; Lakomy, 1990; Melosh, 1989), along with 

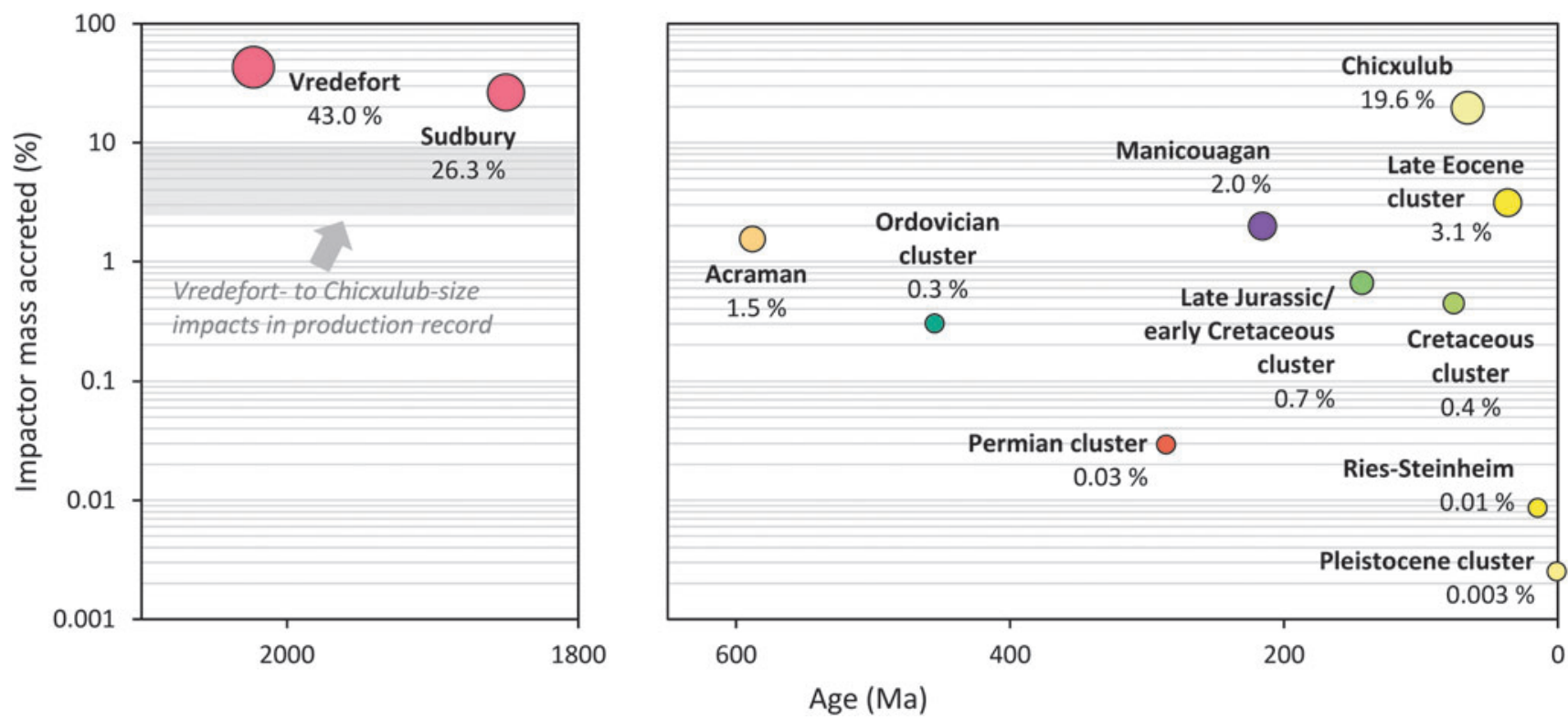

FIG. 6. Graph showing calculated percentage of impactor mass accreted on Earth (logarithmic scale) over the past $\sim 2$ Gyr of geologic time (linear scale) relative to the preserved impact crater record $(n=200)$ as a quantitative measure of the terrestrial impact flux (numbers calculated using equations in Abramov et al., 2012 and best-estimate geologic constraints as input parameters). Note the given percentage values strongly overrepresent these individual impacts when the complete production record over $\sim 2$ Gyr is taken into account; only $\sim 15 \%$ to $25 \%$ of that record is today observed on Earth. Impact crater populations apparent in age distribution diagrams (Fig. 4) may not be very prominent in this type of diagram when they consist of a large number of medium-sized and smaller craters. Apparent impact clusters: Ordovician: 22 impact structures with proven and very likely Ordovician ages; Permian: West Clearwater Lake, Terny and Douglas; Late Jurassic/ Early Cretaceous: Morokweng, Mjølnir, and Dellen; Cretaceous: Kara, Manson, and Lappajärvi ( $~ 78$ to 70 Ma); Late Eocene: Popigai, Chesapeake, Mistastin, and Wanapitei ( 38 to $34 \mathrm{Ma}$ ); Pleistocene: Bosumtwi, Zhamanshin, and Pantasma ( $\sim 1.1$ to $0.8 \mathrm{Ma}$ ). Color scheme as in Fig. 2 and the International Stratigraphic Chart.

reasonable constraints on the type of impactors (e.g., Tagle and Hecht, 2006; Goderis et al., 2012; Koeberl, 2014), their bulk density (e.g., Consolmagno and Britt, 1998; Consolmagno et al., 2008; Macke, 2010; Macke et al., 2011), different types of target rock (e.g., Abramov et al., 2012), and variable impact velocities (e.g., between 10 and 20 $\mathrm{km}^{-1}$ ), the absolute and relative mass flux can be calculated. However, because many of the input parameters are associated with significant uncertainties, these calculations can only provide approximate first-order estimates. For this purpose, we calculated the mass of the three largest impacting bodies based on transient crater diameter values in the literature $(125 \mathrm{~km}$ for Vredefort, $110 \mathrm{~km}$ for Sudbury, and $100 \mathrm{~km}$ for Chicxulub) (Stöffler et al., 1994; Kring, 1995, 2005; Therriault et al., 1997; Grieve and Therriault, 2000). Moreover, such calculations do not take into account the mass accreted from potentially large impacts on Earth that created the Archean spherule layers because the size and type of those projectiles are not well constrained. (One could potentially use the thickness of an ejecta layer as a gauge for the corresponding impactor size, but distal ejecta layers become thinner with distance from their source crater and postimpact sedimentary reworking commonly modifies the thickness of fallout deposits; e.g., McGetchin et al., 1973; Simonson et al., 2000; Byerly et al., 2002; Johnson and Melosh, 2012; Johnson et al., 2016.) Therefore, estimates of the total accreted projectile mass based on the impact crater record alone are minimum estimates.

Doing the relative mass flux calculations for the partially preserved terrestrial impact crater record $(n=200)$ with the above caveat in mind (and not taking into account the [large] impacts that produced the terrestrial impact ejecta deposits), a few things become immediately apparent (Fig. 6): The giant Vredefort impact alone delivered $>40 \%$ of the total projectile mass accreted among all 200 known crater-forming impacts over the last $>2 \mathrm{Gyr}$, and the three largest impact structures on Earth-Vredefort, Sudbury, and Chicxulub-were created by projectiles that together make up $90 \%$ of that total impactor mass. The end-Cretaceous Chicxulub impact concentrates $\sim 70 \%$ of all extraterrestrial mass in the Phanerozoic impact crater record $(n=172)$. In contrast, other relatively large impacts (e.g., Acraman and Manicouagan) in the Ediacaran and Phanerozoic only contributed a small percentage of the total impactor mass. For example, the Ordovician impacts, creating a large group of medium-sized and smaller impact craters with proven and likely Ordovician ages (Fig. 4) (Section 4.1), only delivered $\sim 0.3 \%$ of the total impactor mass (Fig. 6) because those projectiles were, although numerous, relatively small. Seemingly sizeable impact events such as the Ries-Steinheim double impact $14.8 \mathrm{Myr}$ ago (Stöffler et al., 2002; Schmieder et al., 2018a, 2018b) and the three largest Pleistocene impacts (Bosumtwi, Zhamanshin, and Pantasma, not including the enigmatic impact that created the large Australasian tektite strewn field) (e.g., Hartung and Koeberl, 1994; Cavosie, 2018; Rochette et al., 2019), all producing impact craters $>10 \mathrm{~km}$ in diameter, delivered asteroid masses that are statistically insignificant ( $\sim 0.01 \%$ or less). Such calculations put the production rate, relative abundance, and effective significance of large- versus medium-sized 
and small impacts through geologic time (e.g., Grieve and Dence, 1979; Grieve, 2001a, 2001b; Meier and HolmAlwmark, 2017; Rampino and Caldeira, 2017; Mazrouei et al., 2019) into a different perspective.

However, one should also keep in mind that the above relative impactor mass distribution is only relevant to the partially preserved impact crater record observable today $(n=200)$ and, therefore, draws a distorted image of the true impact crater production over time. Assuming Chicxulubsized ( $\sim 180 \mathrm{~km}$ diameter) impacts occur approximately every 100-150 Myr (Grieve and Shoemaker, 1994; Neukum and Ivanov, 1994; French, 1998), the production record for the past $\sim 2 \mathrm{Gyr}$, at a more or less constant impact rate, would contain $\sim 20$ Chicxulub- or Sudbury-sized impacts (producing $\sim 150$ to $200 \mathrm{~km}$-diameter craters), $\sim 77$ Popigai-sized impacts $(\sim 100 \mathrm{~km}), \sim 450$ Siljan-sized impacts $(\sim 50 \mathrm{~km})$, and $\sim 5780$ Ries-sized impacts $(\sim 20 \mathrm{~km})$. Those $>6000$ impacts producing craters $>20 \mathrm{~km}$ in diameter would have delivered several hundred million megatons of impactor material to Earth, only $\sim 6 \%$ of which would have been concentrated in the Vredefort projectile (Chicxulub $\sim 3 \%$ ). The same calculations adjusted for an impact rate $\sim 2$ to 3 times lower before $\sim 0.3 \mathrm{Ga}$ (e.g., Shoemaker, 1998b; Mazrouei et al., 2019) yield roughly 2300 impacts producing craters $>20 \mathrm{~km}$ in diameter over $\sim 2 \mathrm{Gyr}$ (Vredefort $\sim 10 \%$; Chicxulub $\sim 5 \%$ of accreted impactor mass). The above calculations, depending on the cratering rate chosen, suggest that today's partial preservation record $(n=200)$ represents only some $15-25 \%$ of the impact craters produced over the past $\sim 2$ Gyr. These estimates are broadly consistent with those of Johnson and Bowling (2014).

\subsection{Geochronologic evidence for double and multiple impact events on Earth}

There has been an ongoing debate about the geologic and geochronologic evidence for double and multiple impact events on Earth (Spray et al., 1998; Miljković et al., 2013, 2014; Schmieder et al., 2014a, 2014c, 2015a, 2016b). Classic examples of pairs of closely spaced impact craters are the $\sim 25 \mathrm{~km}$ Nördlinger Ries and $\sim 3.8 \mathrm{~km}$ Steinheim Basin in Germany (Stöffler et al., 2002) and the two Clearwater Lakes in Québec, Canada (e.g., Dence et al., 1965; Schmieder et al., 2015a) (Fig. 7). While the age of the Nördlinger Ries is precisely constrained (tektite Ar-Ar age of $14.808 \pm 0.038 \mathrm{Ma}$ ) (Schmieder et al., 2018a, 2018b), the

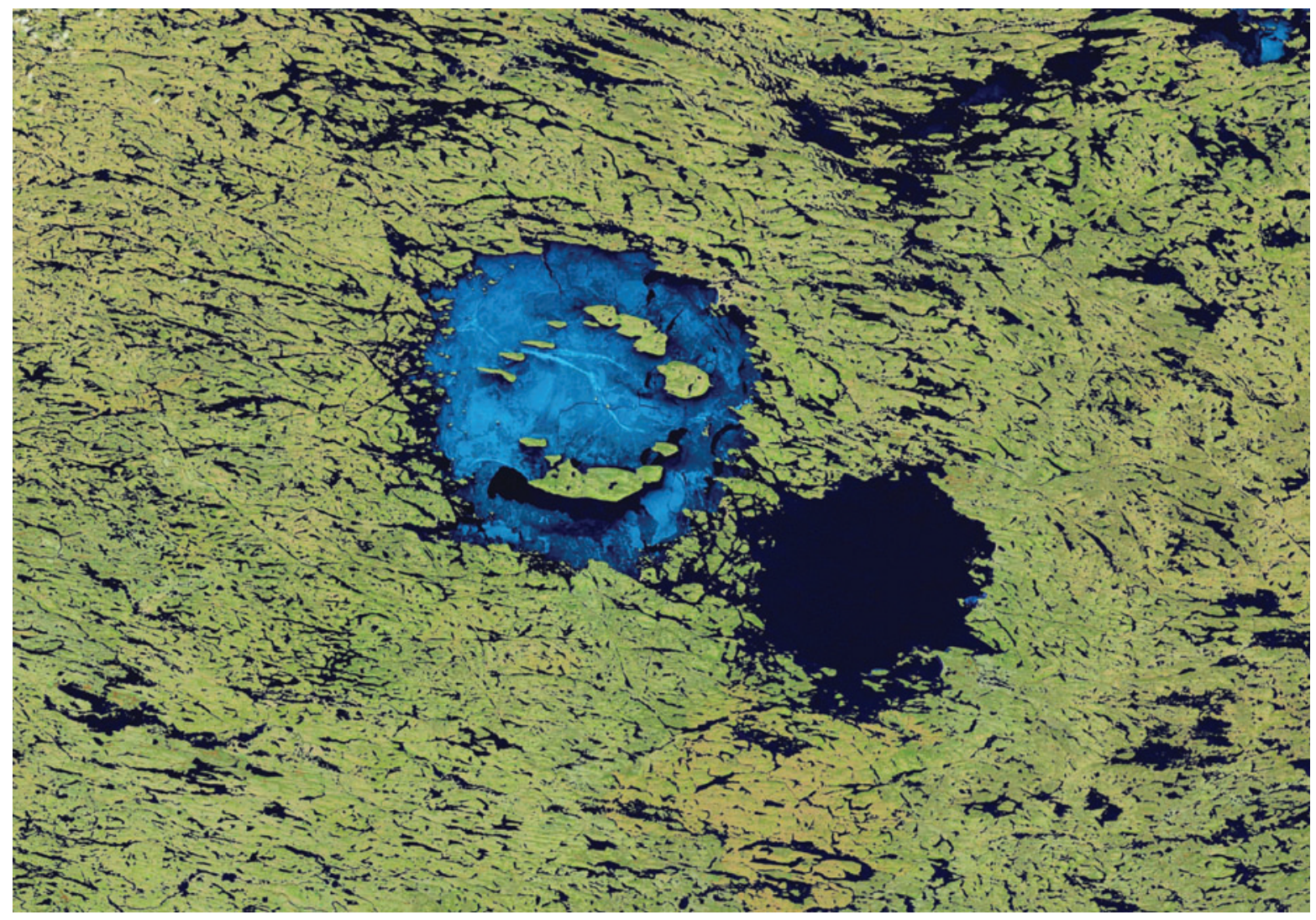

FIG. 7. The two clearwater Lakes in Québec, Canada. The western structure, West Clearwater Lake, is $\sim 36 \mathrm{~km}$ in diameter and has a ring of islands where impact melt-bearing rocks occur. The eastern structure, East Clearwater Lake $\sim 26 \mathrm{~km}$ in diameter, has a more subtle appearance. Both impact structures were considered to represent a 290 million yearold impact crater doublet (Dence et al., 1965; Reimold et al., 1981) until recently. New Ar-Ar geochronologic results, however, demonstrate that the eastern crater formed during the Middle Ordovician ( $\sim 465 \mathrm{Ma})$, a time of intense asteroid bombardment of Earth, whereas the western crater formed in the Early Permian $(\sim 286 \mathrm{Ma})$ and is therefore $\sim 180 \mathrm{Myr}$ younger (Schmieder et al., 2015a). Landsat OLI/TIRS satellite image taken on June 13, 2013, when the western lake was still partly frozen (Source: GloVis, USGS). Scene width $\sim 120 \mathrm{~km}$. OLI, Operational Land Imager; TIRS, Thermal Infrared Sensor. 
age of the Steinheim Basin is still somewhat enigmatic. However, the two impact craters are thought to be genetically linked because of their proximity, the similar age of their Middle Miocene crater lake sediments (Heizmann and Hesse, 1995), and their geometric alignment with the Central European tektite strewn field to the northeast (Stöffler et al., 2002). Clearly, a representative isotopic age for Steinheim would help assess that situation with more confidence; unfortunately, previous $\mathrm{Ar}-\mathrm{Ar}$ results for impactmelted sandstone and (U-Th)/He results for zircon crystals from the central uplift of the complex Steinheim impact crater failed to produce geologically meaningful results (Buchner et al., 2010a).

In Canada, the larger, $\sim 36 \mathrm{~km}$-diameter West Clearwater Lake impact structure has a ring of islands where impact melt-bearing rocks occur. East Clearwater Lake, $26 \mathrm{~km}$ in diameter, has a more subtle appearance and impact melt rock is only known from drillings (e.g., Simonds et al., 1978; Reimold et al., 1981; Grieve, 2006). For almost 50 years, these two impact structures had been considered a textbook example of an impact crater doublet created simultaneously by the impact of a binary asteroid (Dence et al., 1965) in the early Permian some $290 \mathrm{Myr}$ ago (Reimold et al., 1981). However, repeated Ar-Ar analysis (Bottomley et al., 1990; Schmieder et al., 2015a), alongside other lines of geologic evidence (e.g., Scott et al., 1997), eventually made a convincing case against the double impact scenario. While the larger western crater was indeed produced in the Permian at $286.2 \pm 2.6 \mathrm{Ma}$ (Schmieder et al., 2015a), the eastern crater is almost $180 \mathrm{Myr}$ older and, with an age around $465 \mathrm{Ma}$ (Bottomley et al., 1990; Schmieder et al., 2015a; Biren et al., 2016), is part of the prominent Ordovician impact crater population preserved on our planet (Fig. 4 and Table 1).

Two closely spaced impact structures similar in spatial arrangement to the Clearwater Lakes in Canada are the Suvasvesi North and South impact structures in Finland, both $\sim 4 \mathrm{~km}$ in diameter and $\sim 6 \mathrm{~km}$ apart from center to center (e.g., Pesonen et al., 1996b; Lehtinen et al., 2002). Not surprisingly, the two impact structures had previously been considered a possible crater doublet created by the impact of a binary asteroid (Werner et al., 2001). However, more recent $\mathrm{Ar}-\mathrm{Ar}$ and $\mathrm{U}-\mathrm{Pb}$ (zircon) geochronologic results for impact melt rock samples from both structures suggest Suvasvesi South is considerably older ( $\geq 720 \mathrm{Ma}$, i.e., Proterozoic) than the Suvasvesi North structure $(\sim 85$ Ma, Cretaceous). Similar to the two Clearwater Lake impact structures, Suvasvesi North and South seem to constitute a "false" impact crater doublet (Schmieder et al., 2014c, 2016b; Schwarz et al., 2016a). In contrast, the $14 \mathrm{~km}$ diameter Lockne and $0.7 \mathrm{~km}$-diameter Målingen impact structures in Sweden may represent a true crater doublet (Ormö et al., 2014) within the framework of multiple impacts during the Ordovician (see also Section 4.1). A review and geochronologic assessment of these and other proposed terrestrial impact crater doublets (e.g., Gusev and Kamensk in Russia; Movshovic et al. 1991; Melosh and Stansberry, 1991; Bottke and Melosh, 1996; Masaitis, 1999) are provided by Schmieder et al. (2014c).

While the Ordovician period can be regarded as a time of intense impact flux, there is currently no evidence for synchronous multiple impact events resulting in the formation of larger-scale impact crater chains on Earth. Although such a scenario had been proposed for at least five impact structures with overlapping ages (Manicouagan and Lake Saint Martin in Canada, Red Wing Creek in the United States, Rochechouart in France, and Obolon in Ukraine) in the Late Triassic some $214 \mathrm{Myr}$ ago (Spray et al., 1998), more recent $\mathrm{Ar}-\mathrm{Ar}$ age determinations on the Lake Saint Martin (227.8 \pm 0.9 Ma) (Schmieder et al., 2014a) and Rochechouart (206.92 $\pm 0.32 \mathrm{Ma})$ (Cohen et al., 2017; cf. Schmieder et al., 2010b) impacts and refined stratigraphic age constraints for Obolon ( $<185 \mathrm{Ma})$ (Schmieder and Buchner, 2008) demonstrated that all of those craters have very different ages and are thus unrelated. We conclude that the Late Triassic Earth did not see a multiple impact event similar to the impact of several large fragments of comet Shoemaker-Levy 9 on Jupiter as observed by the Hubble Space Telescope in July 1994 (Crawford et al., 1994). While there are geologically old impact crater chains on the Moon and other planetary bodies that formed after the impact of tidally disrupted "rubble pile" asteroids or comets (e.g., Wichman and Wood, 1995; Schenk et al., 1996; Richardson et al., 1998), no such chain is known to exist on Earth and their formation over shorter periods of geologic time is considered very unlikely (Bottke et al., 1997).

\subsection{The role of impacts and impact ages in Earth's biosphere}

With the advent of the "New Catastrophism" in the wake of the impact mass extinction hypothesis, according to which Earth's Mesozoic life-most prominently the dinosaurs - was wiped out due to the impact of a large asteroid that was also the source of a global iridium anomaly (Alvarez et al., 1979, 1980; Ganapathy, 1980; Hsü, 1980; Kyte et al., 1980; Smit and Hertogen, 1980), larger meteorite impacts have been discussed as potential triggers for most, if not all, of the "big five" biological extinction events in the geologic past (e.g., Raup and Sepkoski, 1984; Raup, 1990, 1992; Hodych and Dunning, 1992; Sepkoski, 1996; Hallam and Wignall, 1997; Rampino et al., 1997; Toon et al., 1997; Rampino, 1999; Pálfy, 2004; Reimold et al., 2005, 2008; Kelley, 2007; Racki, 2012; and see also Section 4.1 on impact periodicity). The concept of impact-driven mass extinctions led to the concept of an impact kill curve (Raup, $1990,1992)$ that correlates extinction magnitude or species exterminated with impact crater size. Chicxulub, it was postulated, was particularly devastating because of its large size. That then begged the question: What was the threshold of an extinction level event? It was subsequently recognized that there may be a family of kill curves that reflect extant ambient and biological conditions at the time of impact (Kring, 2002). Yet, the question remained: What is the threshold size of event or events needed to cause extinction? The community has probed that question in two ways. First, an effort has been made to locate evidence of shock metamorphism at mass extinction horizons, which has generated contradictory results (e.g., Retallack et al., 1998 for the endPermian; and Bice et al., 1992; Patzer et al., 2004; Kring et al., 2017a for the Late Triassic). The second approach has been to locate ejecta from other large impact events and determine if they are correlated with extinctions (e.g., Grey et al., 2003; Pálfy, 2004; Clutson et al., 2018). 
The Late Devonian Frasnian/Famennian transition, associated with an extinction event, has an age ( $372 \mathrm{Ma})$ (Percival et al., 2018; cf. Kaufmann, 2006) that is similar to a previously published age of $377 \pm 2 \mathrm{Ma}$ for the $\geq 52 \mathrm{~km}-$ diameter Siljan impact structure in Sweden, Europe's largest impact structure (Reimold et al., 2005). However, current Ar-Ar results suggest that the Siljan impact occurred at either $\sim 400$ or $\sim 380$ Ma (Jourdan and Reimold, 2012). Therefore, a causal link with the Frasnian/Famennian boundary event appears implausible (Racki, 2012). Likewise, there is currently no convincing evidence of globalscale impacts at the end-Permian at $\sim 252 \mathrm{Ma}$ (e.g., Retallack et al., 1998; Reimold and Koeberl, 2000; Renne et al., 2004; Wignall et al., 2004), which marks the biggest of all life crises on Earth during which more than $95 \%$ of marine species and $70 \%$ of terrestrial vertebrates went extinct (e.g., Erwin et al., 2002). The event that created the Permo-Triassic $\sim 40 \mathrm{~km}$-diameter Araguainha impact structure in Brazil, South America's largest impact structure with a U-Pb age of $254.7 \pm 2.5 \mathrm{Ma}$ (Tohver et al., 2012), may have had continent-scale effects (Tohver et al., 2013, 2018), but was likely too small to cause a global biological trauma (e.g., Walkden and Parker, 2008). A more recent set of geochronologic results, moreover, suggests that the Araguainha impact may be somewhat older $(259 \pm 5 \mathrm{Ma})$ (Erickson et al., 2017). Instead, the end-Permian extinction event may have been caused by volcanic activity in large igneous provinces, such as the Emeishan and Siberian Traps in the final stages of the Permian (e.g., Shen et al., 2011; Burgess et al., 2017; Ernst and Youbi, 2017) and potentially other compounding environmental factors.

It appears, however, that there may be a small, but measurable, extinction event that is correlated with the Manicouagan impact event around $\sim 215 \mathrm{Ma}$ (Onoue et al., 2016), which would have produced regional to global environmental consequences (Durda and Kring, 2004; Kring, 2017a) and may be linked to a positive platinum group element anomaly in Upper Triassic deep-sea sediments (Sato et al., 2013). The door on those events has just opened; many more details should be forthcoming now that relevant outcrops have been located for more detailed study. Evidence for impact coinciding with the end-Triassic at $\sim 201 \mathrm{Ma}$ is somewhat dubious (e.g., Olsen et al., 2002; Simms, 2003, 2007; Tanner et al., 2004; Hesselbo et al., 2007; Kring et al., 2007; Schmieder et al., 2010b; Smith, 2011; Lindström et al., 2015), although earlier reports of putative shocked quartz grains at the Triassic/Jurassic boundary in Austria (Badjukov et al., 1987) and Italy (Bice et al., 1992) and an iridium anomaly (Olsen et al., 2002) certainly leave room for new research. The Latest Triassic (Rhaetian) $\sim 40 \mathrm{~km}$-diameter Rochechouart impact structure in France previously had an age that overlapped with the Triassic/Jurassic boundary (Schmieder et al., 2010a), but new $\mathrm{Ar}-\mathrm{Ar}$ results suggest that the impact occurred some $\sim 5$ Myr before the transition (Cohen et al., 2017). Similar to widespread volcanism during the end-Permian, the Central Atlantic Magmatic Province (CAMP) may be a driving force of extensive seismicity, emission of gases, and extinction at the end of the Triassic (e.g., Marzoli et al., 1999; Lindström et al., 2015; Davies et al., 2017).

Thus far, the only convincing case for impact as the trigger of a mass extinction and severe, global-scale pa- leoenvironmental effects remains the giant Chicxulub impact on the Yucatán Peninsula in Mexico, which has been stratigraphically, (micro-)paleontologically, geochemically, and in terms of precise $\mathrm{U}-\mathrm{Pb}$ and $\mathrm{Ar}-\mathrm{Ar}$ ages linked with the Cretaceous/Paleogene boundary at $\sim 66.05 \mathrm{Ma}$ (e.g., Hildebrand et al., 1991; Kring and Boynton, 1991; Toon et al., 1997; Smit, 1999; Kring, 2007; Schulte et al., 2010; Renne et al., 2013, 2018; DePalma et al., 2019). Some of the hazardous paleoenvironmental effects caused by the Chicxulub impact (see Kring, 2007 for a summary) include a roughly Richter magnitude 10.5 earthquake that, in turn, triggered a large-scale tsunami and, in paleolakes and lagoons, forceful seiches (e.g., Smit and Romein, 1985; Bourgeois et al. 1988; DePalma et al., 2019); the global distribution of airborne distal impact ejecta (e.g., Smit, 1999; Claeys et al., 2002); shock-heating of the atmosphere and widespread wildfires caused by the fallout of hot ejecta (e.g., Wolbach et al., 1985; Melosh et al., 1990; Kring and Durda, 2002; Durda and Kring, 2004; Robertson et al., 2013; Belcher et al., 2015); an almost instantaneous phase of "impact winter" caused by atmospheric dust blocking the sunlight (e.g., Vellekoop et al., 2014, 2016; Brugger et al., 2017), followed by a superimposed, slower greenhouse effect in response to the voluminous release of atmospherically active gases (e.g., water vapor, $\mathrm{CO}_{2}$, and $\mathrm{SO}_{\mathrm{x}}$ ) from the carbonate- and sulfate-dominated target rock (Kring et al., 1996; Pope et al., 1997; Pierazzo et al., 1998; Kring, 2007); and the acidification of ocean water and leaching of soil due to acid rain (e.g., Prinn and Fegley, 1987; Retallack et al., 1987; D’Hondt et al., 1994; Retallack, 1996). At the time of impact, the contemporaneous Deccan trap volcanism in India had already been active (Renne et al., 2015; Richards et al., 2015).

It is worth noting that large impacts, capable of causing widespread havoc and mass extinctions, do not only have detrimental effects on the biosphere. While the endOrdovician extinction ( $\sim 443 \mathrm{Ma}$ ) was most likely related to climatic effects and glaciation (e.g., Wang et al., 2019), some researchers have argued that frequent impacts during the mid-Ordovician ( $\sim 470$ to $458 \mathrm{Ma}$ ) may have, in fact, boosted biodiversification (Schmitz et al., 2008). A similar biodiversification effect among fossil plankton was also proposed for the Acraman impact in the Ediacaran (Grey et al., 2003), a time when more highly organized organisms emerged (e.g., Knoll et al., 2006); stratigraphic and isotopic age constraints for the Acraman impact are, however, relatively imprecise (Schmieder et al., 2015b). Recently, Erickson et al. (2019a, 2019b) suggested the $\sim 2.23 \mathrm{Ga}$ Yarrabubba impact in Western Australia, which potentially affected a Paleoproterozoic "Snowball Earth," may have been a trigger mechanism for the release of large amounts of water vapor into the atmosphere (Kring, 2003), thereby creating a warming effect that may have helped Earth escape its icehouse state (see also Koeberl et al., 2007b; Koeberl and Ivanov, 2019).

\subsection{High-precision impact geochronology and its relevance to exo- and astrobiology}

Could life have first flourished on Earth beneath the floor of an impact crater? This question (the Impact-Origin of Life Hypothesis) (Kring, 2000, 2019) has not been answered 
quite yet, but an integral part of it-a temporal component studied in detail using high-precision geochronologic techniques - is a core aspect of this work. As formulated in previous studies suggesting that the origin of life may lie in impact crater settings (e.g., Kring 2000, 2003, 2019; Cockell and Lee, 2002; Ryder, 2002; Osinski, 2003, 2011; Cockell, 2006), cooling impact craters that hosted hydrothermal systems are thought to have served as a habitat for microbial life on the early Earth and, possibly, Mars (e.g., Abramov and Mojzsis, 2009; Osinski et al., 2013, 2017; Rummel et al., 2014; Grimm and Marchi, 2018; Bowling and Marchi, 2018).

A number of geo-biological paleoenvironmental settings have been proposed as potential loci for the origin and evolution of microbial life on the Hadean-Eoarchean Earth more than 3.8 Ga ago (e.g., Nisbet and Sleep, 2001); a recent review is provided by Westall et al. (2018). These settings include, among others, sulfide-rich hydrothermal vents (e.g., Baross and Hoffman, 1985; Russell and Hall, 1997; Russell and Arndt, 2005; Martin et al., 2008) and hydrothermal-sedimentary crustal settings, in which prebiotic molecules may have been initially produced, stabilized, and complexified as a starting material for organic life (e.g., Westall et al., 2018). Impact craters and basins on the early Earth, hosting extensive postimpact hydrothermal systems, would have provided a very similar promising setting (e.g., Abramov and Kring, 2004). The largest asteroid impacts on the Hadean and Eoarchean Earth more than $3.7 \mathrm{Ga}$ ago would have created at least $\sim 40$ basins $\sim 1000 \mathrm{~km}$ in diameter and several of order $5000 \mathrm{~km}$-diameter (Grieve, 1980; Kring and Cohen, 2002; Kring, 2003; Grieve et al., 2006) and would have, at the same time, delivered prebiotically relevant elements, such as structurally bound water, carbon, nitrogen, phosphorous, and sulfur (e.g., Kring and Cohen, 2002; Pasek and Lauretta, 2008; Svetsov and Shuvalov, 2015; Barnes et al., 2016) (compare Section 4.2 and Fig. 6). However, smaller impact craters some tens of $\mathrm{km}$ across would have been much more abundant and saturated Earth's surface (e.g., Abramov and Mojzsis, 2009). While the largest of those impact events likely vaporized surface water (Sleep et al., 1989; Zahnle and Sleep, 2006) and produced large amounts of impact melt (e.g., Grieve and Cintala, 1992; Grieve et al., 2006), making surface conditions untenable for life, numerical models suggest the subsurface was still habitable (Abramov and Kring, 2004, 2005, 2007; Abramov and Mojzsis, 2009; Grimm and Marchi, 2018). Basin-sized and smaller impacts would have produced subsurface hydrothermal systems conducive for prebiotic chemical reactions that could have led to the early evolution of microbes (e.g., Kring, 2000, 2003; Ryder, 2002; Bowling and Marchi, 2018). The volumes of impactgenerated habitable zones for mesophilic, thermophilic, and hyperthermophilic microbial life forms in the subsurface of the Hadean-Eoarchean Earth (i.e., inside impact craters and the fractured crust below) were significant (of order $\sim 10^{9} \mathrm{~km}^{3}$ ) (Abramov and Mojzsis, 2009). As with the flux of impactor mass over time (see Section 4.2), the largest impact structures would have provided the most voluminous hydrothermally altered and habitable zones. The volume of rock that sustained habitable temperatures $\left(\leq 110^{\circ} \mathrm{C}\right)$ over hundreds of thousands of years attained up to $\sim 40,000 \mathrm{~km}^{3}$ in larger impact structures $\sim 200 \mathrm{~km}$ across (Abramov and Kring, 2004). The colonization of the central domains of such impact craters may have occurred some $\sim 20,000$ years after the impact (Abramov and Kring, 2004; Abramov and Mojzsis, 2009). This estimate is consistent with the relatively rapid recovery of life at ground zero inside the Chicxulub crater after $\sim 30,000$ years (Lowery et al., 2018).

Although large impacts were much more abundant during the Hadean and Archean before ca. 3.7 Ga (e.g., Turner et al., 1973; Tera et al., 1974; Ryder, 1990; Kring and Cohen, 2002; Bottke and Norman, 2017), impact craters and their hydrothermally altered rocks and minerals accessible on Earth today (e.g., Allen et al., 1982; Osinski et al., 2001, 2013; Zürcher and Kring, 2004; Naumov, 2005; Kring et al., 2017b) are valuable analog sites for the type of impactproduced, wet, and warm habitat described above. Putative fossils of microbial life found in hydrothermally altered impact glass, for example, at the early Cretaceous, $19 \mathrm{~km}$ diameter Dellen impact structure in Sweden (Lindgren et al., 2010) and the Miocene Ries crater in Germany (Sapers et al., 2014, 2015), as well as sulfur isotopic signatures indicating microbial reduction of target rock sulfate at the Miocene, $\sim 24 \mathrm{~km}$-diameter Haughton impact structure, Canada (Parnell et al., 2010), and the latest Triassic, $\sim 40 \mathrm{~km}$-diameter Rochechouart impact structure, France (Simpson et al., 2017), may be evidence for the colonization of impact crater-hosted habitabile zones by thermophilic microbes. Figure 8 shows a variety of impactites typically found in terrestrial impact structures, including lithologies enriched in biologically relevant elements (such as carbon and sulfur) and hydrothermally altered rocks that may represent analogues for the setting in impact crater-hosted microbial habitats (e.g., Kring, 2000, 2003; Ryder, 2002; Cockell et al., 2003; Cockell, 2006).

In addition to habitable volumes and substrates, two key factors in hot fluid systems as biological habitats are their temperature and lifetime. Geochronologic studies and numerical modeling suggest that the largest terrestrial impact craters, such as Sudbury and Chicxulub, may have sustained initially hot $\left(>300^{\circ} \mathrm{C}\right)$ hydrothermal systems for more than 2 Myr (e.g., Ames et al., 1998; Abramov and Kring, 2004, 2007; Zürcher and Kring, 2004), whereas medium-sized impact craters around $20-30 \mathrm{~km}$ in diameter were generally thought to cool down more rapidly, perhaps over a few thousands or tens of thousands of years (e.g., Pohl et al., 1977; Osinski et al., 2001). Recent high-precision U-Pb and $\mathrm{Ar}-\mathrm{Ar}$ results for the $23 \mathrm{~km}$-diameter Lappajärvi impact crater in Finland, however, suggest those initial estimates may have been too conservative. An older zircon $\mathrm{U}-\mathrm{Pb}$ age of $\sim 77.85 \mathrm{Ma}$, recording lead diffusion at $\sim 900^{\circ} \mathrm{C}$ (Kenny et al., 2019b), in combination with significantly younger ArAr results of $\sim 76$ to $75 \mathrm{Ma}$ for impact melt rock and Kfeldspar that record argon diffusion at $\sim 400$ to $200^{\circ} \mathrm{C}$ over several hundred thousand years (Schmieder and Jourdan, 2013a), indicates that even the comparatively small Lappajärvi crater cooled down from initially hot, impact melt-producing temperatures $\left(>2000^{\circ} \mathrm{C}\right.$ ) (Bischoff and Stöffler, 1984) to hotter-than-habitable conditions over a period of at least 1.3 Myr (Kenny et al., 2019b). This demonstrates that modern isotopic techniques have the capacity to resolve various stages of an impact event as a protracted geologic process rather than an instantaneous event. It is becoming more apparent that the most precise and accurate impact ages are obtained by using high-temperature geochronometers and/ 

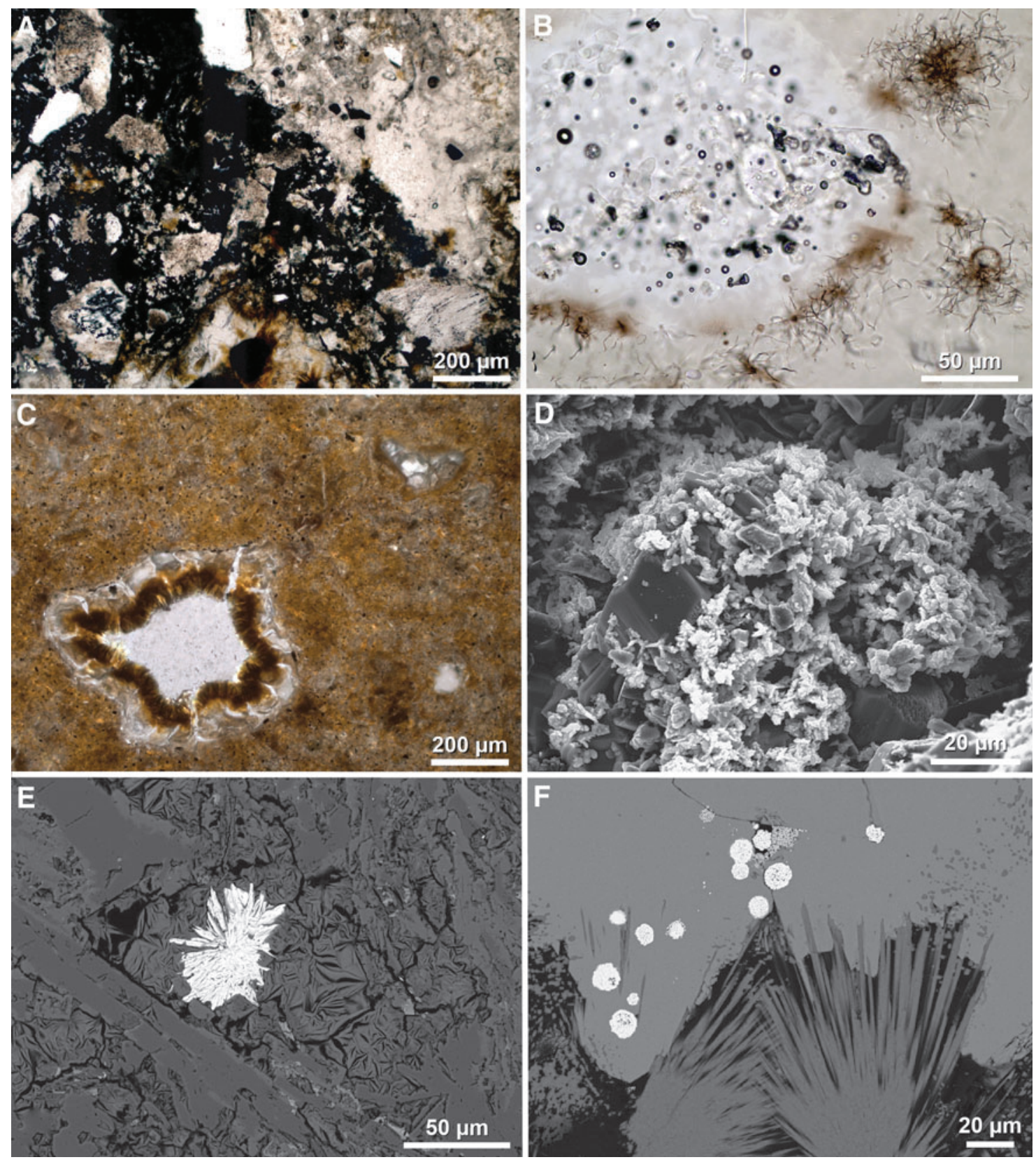

FIG. 8. Impact lithologies with biologically relevant elements and/or evidence of hydrothermal alteration as potential analogues for impact crater-hosted microbial habitats. (A) Impact melt breccia rich in carbon (enriched in dark interstitial material) from the $\sim 5 \mathrm{~km}$-diameter Gardnos impact structure, Norway. (B) Impact glass from the Nördlinger Ries, Germany, with vesicular domain of silica glass (lechatelierite) and whiskers (trichites) of pyroxene; this type of glass has been linked with possible evidence of fossil microbial life (e.g., Lindgren et al., 2010; Sapers et al., 2014, 2015). (C) Hydrothermally altered impact melt rock with larger vesicle lined by secondary clay minerals from the $\sim 80 \mathrm{~km}$ PuchezhKatunki impact structure, Russia. (A-C) Optical images, plane-polarized light. (D) Altered and locally corroded K-feldspar overgrown by clay minerals in shock-recrystallized and hydrothermally altered granite from the Lappajärvi impact structure, Finland. Unaltered K-feldspar (darker gray) from this sample was used for high-precision Ar-Ar geochronology (Schmieder and Jourdan, 2013a). Secondary electron image. (E) Clay alteration domain (gray, with irregular cracks) and secondary barite (Ba-sulfate) in altered impact melt rock from the $\sim 90 \mathrm{~km}$-diameter Acraman impact structure, South Australia (Williams, 1994; Schmieder et al., 2015b). (F) Small pyrite (Fe-sulfide) framboids in zeolite (light gray: analcime; darker gray: Na-dachiardite) in hydrothermally altered reworked suevitic breccia from the $180 \mathrm{~km}$-diameter Chicxulub impact crater (Kring et al., 2017b). (E, F) Backscattered electron images. 


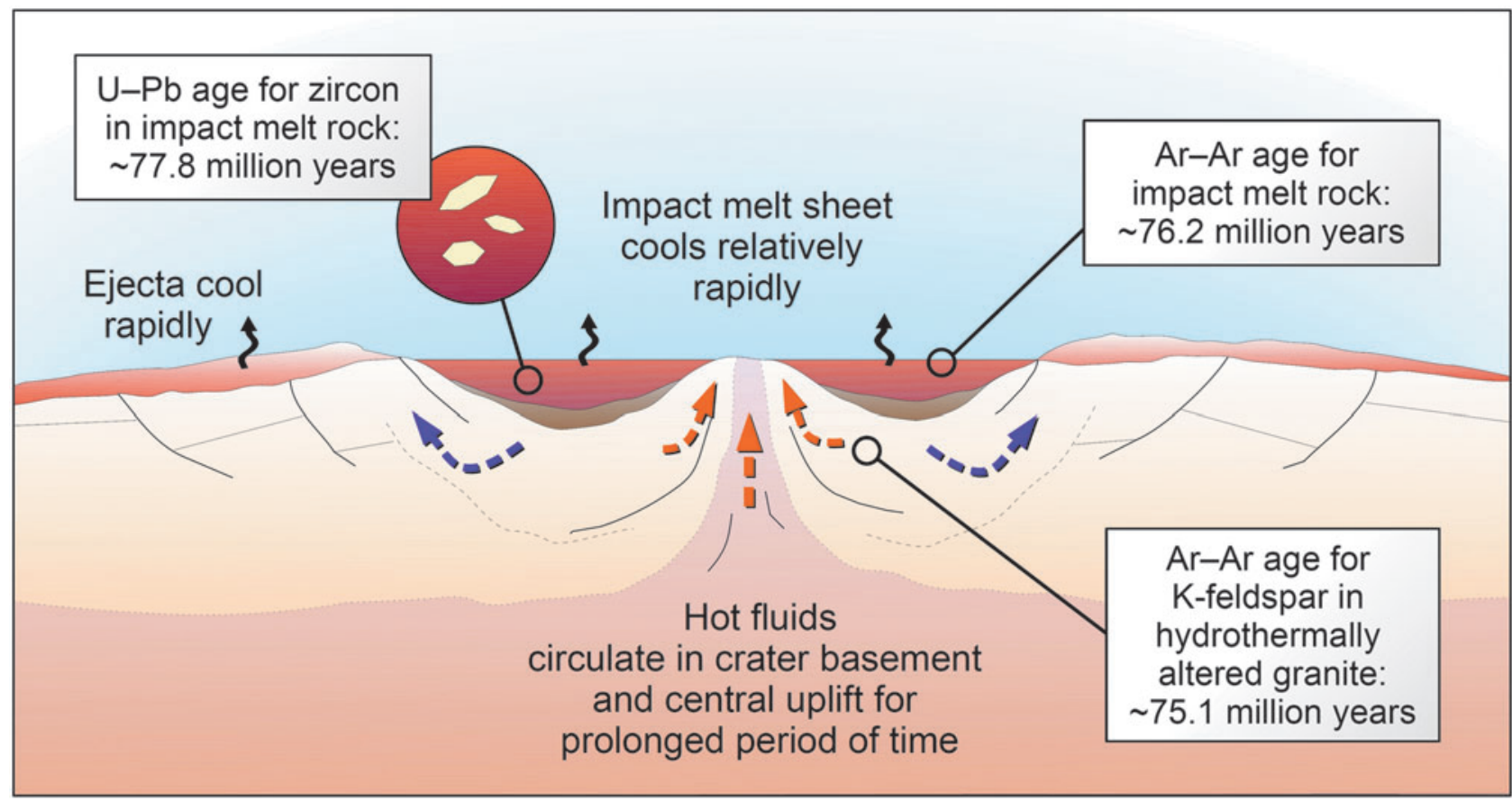

FIG. 9. Schematic illustration of a cooling complex impact crater (cross-sectional view), for example, the $\sim 23 \mathrm{~km}-$ diameter Lappajärvi impact structure in Finland, modified after Schmieder and Jourdan (2013b). High-precision geothermochronologic results for different types of lithologies can resolve the crater cooling process. Whereas the impact melt sheet and impact eject cool relatively fast, the central uplift of the structure maintains the circulation of hot fluids for a prolonged period of time. The hottest temperature in that hydrothermal system occurs in the central, uplifted domain of the impact crater; whereas fluids in the crater rim domain are comparatively cool (compare Abramov and Kring, 2004, 2005, 2007). Age values indicated are actual results for Lappajärvi, taken from Schmieder and Jourdan (2013a) and Kenny et al. (2019b). Uranium-lead and Ar-Ar results for rapidly cooled impact ejecta (e.g., ejected shocked zircon grains and tektites) have, thus far, provided the best-estimate age for impact events. In contrast, hydrothermally altered rocks and minerals commonly yield ages reflecting protracted postimpact fluid flow that can locally last for $>1$ Myr in impact structures $>20 \mathrm{~km}$ in diameter (e.g., Schmieder et al., 2018a; Kenny et al., 2019b).

or, if available, rapidly cooled (distal) impact melt lithologies that landed (far) outside their hot and slowly cooling source crater (Schmieder et al., 2018a; Kenny et al., 2019b). More importantly, the slow cooling of the Lappajärvi crater resolved by combined high-resolution $\mathrm{U}-\mathrm{Pb}$ and $\mathrm{Ar}-\mathrm{Ar}$ geochronology makes medium-sized impact craters $(\sim 20$ to $30 \mathrm{~km}$ in diameter), which are orders of magnitude more common over geologic time than Sudbury- or Chicxulubsized craters (e.g., French, 1998), an important type of habitat for thermophilic and hyperthermophilic microbes on the early Earth (Kring, 2000, 2003; Cockell et al., 2003; Cockell, 2006). A scheme of a slow-cooling complex impact crater, such as Lappajärvi, is shown in Fig. 9. Slowly cooling impact crater-hosted hydrothermal systems similar in volume and lifetime to that at Lappajärvi are, therefore, also relevant to astro- and exobiology. In analogy to Earth, medium-sized impact craters on early (Noachian) Mars may have been an important extraterrestrial habitat, as well (e.g., Newsom, 1980; Newsom et al., 1986, 2001; Rathbun and Squyres, 2002; Abramov and Kring, 2005; Schwenzer and Kring, 2009; Osinski et al., 2013; Rummel et al., 2014; Abramov and Mojzsis, 2016).

\section{Conclusions}

This work presents a comprehensive collection of revised ages for terrestrial impact structures and deposits. Impact geochronology and the use of the U-Pb and $\mathrm{Ar}-\mathrm{Ar}$ techniques and other methods have significantly refined the time line for a number of impact events on Earth, whose ages can be correlated with other impacts and geologic events in Earth history, and which can be used to assess the impact (mass) flux on Earth through geologic time. Based on the latest geochronologic results, synchronous double impacts on Earth seem to be rare, and evidence for a large-scale multiple impact event on our planet is currently missing. However, the Ordovician marks a time period of intense bombardment over several million years, supported by a growing number of Ordovician $\mathrm{U}-\mathrm{Pb}, \mathrm{Ar}-\mathrm{Ar}$, and stratigraphic impact ages. Only the Chicxulub impact at the K/T boundary $66.05 \mathrm{Myr}$ ago has been firmly linked to a mass extinction event, in part, based on high-precision $\mathrm{U}-\mathrm{Pb}$ and Ar-Ar results. The latter can also be used to determine the lifetime of hydrothermal systems in cooling impact craters, as recently done for the slowly cooled Lappajärvi impact crater in Finland as an analog site for impact crater-hosted habitats for microbial life on the early Earth and, possibly, Mars.

\section{Acknowledgments}

We thank Drs. Timmons Erickson (NASA Johnson Space Center, Jacobs_JETS), Thomas Kenkmann (University of Freiburg), Gavin Kenny (Swedish Museum of Natural 
History), Irmeli Mänttäri (Geological Survey of Finland), Annemarie Pickersgill (University of Glasgow), and Birger Schmitz (University of Lund) for discussion and information about some of the impact ages reported in this article. We also thank Drs. Christian Koeberl and Gordon Osinski and an anonymous reviewer for their constructive reviews, as well as Editor Dr. Sherry Cady for her careful handling of our article.

\section{Author Disclosure Statement}

No competing financial interests exist.

\section{Funding Information}

This work was supported by the NASA Solar System Exploration Research Virtual Institute (SSERVI) contract NNA14AB07A (D.A.K., principal investigator). This is LPI Contribution number 2217. LPI is operated by USRA under a cooperative agreement with the Science Mission Directorate of the National Aeronautics and Space Administration.

\section{References}

Abels, A. (2003) Investigation of impact structures in Finland (Söderfjärden, Lumparn, Lappajärvi) by digital integration of multidisciplinary geodata. Doctoral thesis, Westfälische Wilhelms-Universität, Münster, Germany, $321 \mathrm{p}$.

Abels, A. (2005) Spider impact structure, Kimberley Plateau, Western Australia: interpretations of formation mechanism and age based on integrated map-scale data. Aust J Earth Sci 52:653-664.

Abels, A., Plado, J., Pesonen, L.J., and Lehtinen, M. (2002) The impact cratering record of Fennoscandia-a close look at the database. In Impacts in Precambrian Shields, edited by J. Plado and L.J. Pesonen, Springer, Berlin, Heidelberg, pp 1-58.

Abramov, O. and Kring, D.A. (2004) Numerical modeling of an impact-induced hydrothermal system at the Sudbury crater. J Geophys Res Planets 109:16.

Abramov, O. and Kring, D.A. (2005) Impact-induced hydrothermal activity on early Mars. J Geophys Res Planets 110:19.

Abramov, O. and Kring, D.A. (2007) Numerical modeling of impact-induced hydrothermal activity at the Chicxulub crater. Meteorit Planet Sci 42:93-112.

Abramov, O. and Mojzsis, S.J. (2009) Microbial habitability of the Hadean Earth during the late heavy bombardment. Nature 459:419-422.

Abramov, O. and Mojzsis, S.J. (2016) Thermal effects of impact bombardments on Noachian Mars. Earth Planet Sci Lett 442: 108-120.

Abramov, O., Wong, S.M., and Kring, D.A. (2012) Differential melt scaling for oblique impacts on terrestrial planets. Icarus 218:906-916.

Addison, W.D., Brumpton, G.R., Vallini, D.A., McNaughton, N.J., Davis, D.W., Kissin, S.A., Fralick, P.W., and Hammond, A.L. (2005) Discovery of distal ejecta from the $1850 \mathrm{Ma}$ Sudbury impact event. Geology 33:193-196.

Allen, C.C., Gooding, J.L., and Keil, K. (1982) Hydrothermally altered impact melt rock and breccia: contributions to the soil of Mars. J Geophys Res Solid Earth 87:10083-10101.

Alvarez, W., Alvarez, L.W., Asaro, F., and Michel, H.V. (1979) Anomalous iridium levels at the Cretaceous/Tertiary boundary at Gubbio, Italy. In Cretaceous-Tertiary Boundary Events
Symposium, W.K. Christensen and T. Birkelund, Vol. 2. University of Copenhagen, Denmark, p 69.

Alvarez, L.W., Alvarez, W., Asaro, F., and Michel, H.V. (1980) Extraterrestrial cause for the Cretaceous-Tertiary extinction. Science 208:1095-1108.

Alvarez, W. and Muller, R.A. (1984) Evidence from crater ages for periodic impacts on the Earth. Nature 308:718-720.

Alwmark, C. (2009) Shocked quartz grains in the polymict breccia of the Granby structure, Sweden-verification of an impact. Meteorit Planet Sci 44:1107-1113.

Alwmark, C. and Schmitz, B. (2007) Extraterrestrial chromite in the resurge deposits of the early Late Ordovician Lockne crater, central Sweden. Earth Planet Sci Lett 253:291-303.

Alwmark, C. and Schmitz, B. (2009) The origin of the Brunflo fossil meteorite and extraterrestrial chromite in midOrdovician limestone from the Gärde quarry (Jämtland, central Sweden). Meteorit Planet Sci 44:95-106.

Alwmark, C., Schmitz, B., and Kirsimäe, K. (2010) The midOrdovician Osmussaar breccia in Estonia linked to the disruption of the L-chondrite parent body in the asteroid belt. GSA Bull 122:1039-1046.

Alwmark, C., Ferrière, L., Holm-Alwmark, S., Ormö, J., Leroux, H., and Sturkell, E. (2015) Impact origin for the Hummeln structure (Sweden) and its link to the Ordovician disruption of the L chondrite parent body. Geology 43: 279-282.

Alwmark, C., Bleeker, W., LeCheminant, A., Page, L., and Scherstén, A. (2017) An early Ordovician ${ }^{40} \mathrm{Ar}-{ }^{39} \mathrm{Ar}$ age for the $\sim 50 \mathrm{~km}$ Carswell impact structure, Canada. GSA Bull 129:1442-1449.

Ames, D.E., Watkinson, D.H., and Parrish, R.R. (1998) Dating of a regional hydrothermal system induced by the $1850 \mathrm{Ma}$ Sudbury impact event. Geology 26:447-450.

Assis Fernandes, V., Hopp, J., Schwarz, W.H., Fritz, J.P., Trieloff, M., and Povenmire, H. (2019) ${ }^{40} \mathrm{Ar}^{-}{ }^{39} \mathrm{Ar}$ step heating ages of North American tektites and of impact melt rock samples from the Chesapeake Bay impact structure. Geochim Cosmochim Acta 255:289-308.

Badjukov, D.D., Lobitzer, H., and Nazarov, M.A. (1987) Quartz grains with planar features in the Triassic-Jurassic boundary sediments from Northern Limestone Alps, Austria. Lunar Planet Sci 18:38-39.

Bailer-Jones, C.A. (2011) Bayesian time series analysis of terrestrial impact cratering. Month Not Royal Astronom Soc 416: 1163-1180.

Baksi, A.K. (1990) Search for periodicity in global events in the geologic record: quo vadimus? Geology 18:983-986.

Baldwin, R.B. (1971) On the history of lunar impact cratering: the absolute time scale and the origin of planetesimals. Icarus 14:36-52.

Banet, A.C. and Fenton, J.P.G. (2008) An examination of the Simpson core test wells suggests an age for the Avak impact feature near Barrow, Alaska. In The Sedimentary Record of Meteorite Impacts, GSA Special Paper 437, edited by K. Evans, J.W. Horton, Jr., D.T. King, and J.R. Morrow, Geological Society of America, Boulder, CO, pp 139-145.

Baratoux, D., Bouley, S., Baratoux, L., Colas, F., Dauvergne, J.L., Vaubaillon, J., Chennaoui-Aoudjehane, H., Jambon, A., Gattacceca, J., Losiak, A., and Bourdeille, C. (May 16-20, 2012) Karakul depression, Tadjikistan-A Young Impact Crater? [abstract 6037]. In Proceedings of the Asteroids, Comets, Meteors Conference, Niigata. LPI Contribution No. 1667. 
Barnes, J.J., Kring, D.A., Tartèse, R., Franchi, I.A., Anand, M., and Russell, S.S. (2016) An asteroidal origin for water in the Moon. Nat Commun 7:11684.

Baross, J.A. and Hoffman, S.E. (1985) Submarine hydrothermal vents and associated gradient environments as sites for the origin and evolution of life. Orig Life Evol Biosph 15: 327-345.

Barrows, T.T., Magee, J., Miller, G., and Fifield, L.K. (2019). The age of Wolfe Creek meteorite crater (Kandimalal), Western Australia. Meteorit Planet Sci 54:2686-2697.

Basurah, H.M. (2003) Estimating a new date for the Wabar meteorite impact. Meteorit Planet Sci 38:A155-A156.

Beauford, R.E. (2015) Physical records of impacts in the early and modern solar system. PhD thesis, University of Arkansas, Fayetteville, Arkansas, 174 p.

Beauford, R.E. (2019) United States Meteorite Impact Craters. Available online at https://impactcraters.us, accessed March 30, 2016.

Belcher, C.M., Hadden, R.M., Rein, G., Morgan, J.V., Artemieva, N., and Goldin, T. (2015) An experimental assessment of the ignition of forest fuels by the thermal pulse generated by the Cretaceous-Palaeogene impact at Chicxulub. J Geol Soc 172:175-185.

Bergström, S.M., Schmitz, B., Liu, H.P., Terfelt, F., and McKay, R.M. (2018) High-resolution $\delta^{13} \mathrm{C}_{\mathrm{org}}$ chemostratigraphy links the Decorah impact structure and Winneshiek Konservat-Lagerstätte to the Darriwilian (Middle Ordovician) global peak influx of meteorites. Lethaia 51: 504-512.

Bevan, A.W.R. (2006) Desert meteorites: a history. Geol Soc London Spec Pub 256:325-343.

Bice, D.M., Newton, C.R., McCauley, S., Reiners, P.W., and McRoberts, C.A. (1992) Shocked quartz at the TriassicJurassic boundary in Italy. Science 255:443-446.

Bigazzi, G. and De Michele, V. (1996) New fission-track age determinations on impact glasses. Meteorit Planet Sci 31: 234-236.

Biren, M.B., van Soest, M., Wartho, J.A., and Spray, J.G. (2014) Dating the cooling of exhumed central uplifts of impact structures by the (U-Th)/He method: a case study at Manicouagan. Chem Geol 377:56-71.

Biren, M.B., van Soest, M.C., Wartho, J.A., Hodges, K.V., and Spray, J.G. (2016) Diachroneity of the Clearwater West and Clearwater East impact structures indicated by the (U-Th)/He dating method. Earth Planet Sci Lett 453:56-66.

Biren, M.B., Wartho, J.A., van Soest, M.C., Hodges, K.V., Cathey, H., Glass, B.P., Koeberl, C., Horton, J.W., Jr., and Hale, W. (2019) (U-Th)/He zircon dating of Chesapeake Bay distal impact ejecta from ODP site 1073. Meteorit Planet Sci 54:1840-1852.

Bischoff, A. and Stöffler, D. (1984) Chemical and structural changes induced by thermal annealing of shocked feldspar inclusions in impact melt rocks from Lappajärvi crater, Finland. J Geophys. Res Solid Earth 89:B645-B656.

Bland, P.A. (2005) The impact rate on Earth. Phil Trans $R$ Soc Lond A 363:2793-2810.

Bland, P.A., de Souza Filho, C.R., Jull, A.T., Kelley, S.P., Hough, R.M., Artemieva, N.A., Pierazzo, E., Coniglio, J., Pinotti, L., Evers, V., and Kearsley, A.T. (2002) A possible tektite strewn field in the Argentinian Pampa. Science 296: 1109-1111.

Bogard, D.D., Husain, L., and Wright, R.J. (1976) ${ }^{40} \mathrm{Ar}-{ }^{39} \mathrm{Ar}$ dating of collisional events in chondrite parent bodies. $J$ Geophys Res 81:5664-5678.
Bogard, D.D., Garrison, D.H., Norman, M., Scott, E.R.D., and Keil, K. (1995) ${ }^{39} \mathrm{Ar}-{ }^{40} \mathrm{Ar}$ age and petrology of Chico: largescale impact melting on the $\mathrm{L}$ chondrite parent body. Geochim Cosmochim Acta 59:1383-1399.

Borovička, J., Spurný, P., Brown, P., Wiegert, P., Kalenda, P., Clark, D., and Shrbený, L. (2013) The trajectory, structure and origin of the Chelyabinsk asteroidal impactor. Nature 503:235-237.

Boschi, S., Schmitz, B., Heck, P.R., Cronholm, A., Defouilloy, C., Kita, N.T., Monechi, S., Montanari, A., Rout, S.S., and Terfelt, F. (2017) Late Eocene ${ }^{3} \mathrm{He}$ and Ir anomalies associated with ordinary chondritic spinels. Geochim Cosmochim Acta 204:205-218.

Bottke, W.F., Jr. and Melosh, H.J. (1996) Binary asteroids and the formation of doublet craters. Icarus 124:372-391.

Bottke, W.F. and Norman, M.D. (2017) The Late Heavy Bombardment. Ann Rev Earth Planet Sci 45:619-647.

Bottke, W.F., Richardson, D.C., and Love, S.G. (1997) Can tidal disruption of asteroids make crater chains on the Earth and Moon? Icarus 126:470-474.

Bottke, W.F., Jedicke, R., Morbidelli, A., Petit, J.M., and Gladman, B. (2000) Understanding the distribution of nearEarth asteroids. Science 288:2190-2194.

Bottke, W.F., Vokrouhlický, D., and Nesvorný, D. (2007) An asteroid breakup $160 \mathrm{Myr}$ ago as the probable source of the K/T impactor. Nature 449:48-53.

Bottomley, R.J. and York, D. (1988) Age measurement of the submarine Montagnais impact crater. Geophys Res Lett 15: 1409-1412.

Bottomley, R.J., York, D., and Grieve, R.A.F. (1979) Possible source craters for the North American tektites-a geochronological investigation. EOS Trans Am Geophys Union 60: 309.

Bottomley, R.J., York, D., and Grieve, R.A.F. (1990) ${ }^{40}$ Argon- ${ }^{39}$ Argon dating of impact craters. Proc Lunar Planet Sci Conf 20:421-431.

Bottomley, R., Grieve, R., York, D., and Masaitis, V. (1997) The age of the Popigai impact event and its relation to events at the Eocene/Oligocene boundary. Nature 388:365-368.

Bourgeois, J., Hansen, T.A., Wiberg, P.L., and Kauffman, E.G. (1988) A tsunami deposit at the Cretaceous-Tertiary boundary in Texas. Science 241:567-570.

Bowling, T.J. and Marchi, S. (2018) Revisiting the origin and evolution of habitable environments in post-impact hydrothermal systems beneath martian Craters [abstract 2654]. In Lunar and Planetary Science XLIX, The Woodlands, TX: LPI Contribution No. 2083.

Brandt, D. and Reimold, W.U. (1995) The geology of the Pretoria Saltpan impact structure and the surrounding area. S Afr J Geol 98:287-303.

Brandt, D., Holmes, H., Reimold, W.U., Paya, B.K., Koeberl, C., and Hancox, P.J. (2002) Kgagodi Basin: the first impact structure recognized in Botswana. Meteorit Planet Sci 37: 1765-1779.

Brenan, R.L., Peterson, B.L., and Smith, H.J. (1975) The origin of Red Wing Creek structure: McKenzie County, North Dakota. Earth Sci Bull 8:1-42.

Bron, K.A. and Gostin, V. (2012) The Tookoonooka marine impact horizon, Australia: sedimentary and petrologic evidence. Meteorit Planet Sci 47:296-318.

Brugger, J., Feulner, G., and Petri, S. (2017) Baby, it's cold outside: climate model simulations of the effects of the asteroid impact at the end of the Cretaceous. Geophys Res Lett 44:419-427. 
Bucher, W.H. (1936) Cryptovolcanic structures in the United States. In 16th International Geological Congress, Vol. 2, Washington, DC, pp 1055-1084.

Buchner, E., Schmieder, M., Schwarz, W.H., Trieloff, M., Jourdan, F., Wartho, J.A., van Soest, M.C., Hodges, K.V., and Pösges, G. (2010a) A new look at the Ries-Steinheim event [abstract 2151]. In Lunar and Planetary Science XLI. Lunar and Planetary Institute, Houston TX.

Buchner, E., Schwarz, W.H., Schmieder, M., and Trieloff, M. (2010b) Establishing a 14.6 $\pm 0.2 \mathrm{Ma}$ age for the Nördlinger Ries impact (Germany) - a prime example for concordant isotopic ages from various dating materials. Meteorit Planet Sci 45:662-674.

Buchner, E., Schmieder, M., Schwarz, W.H., and Trieloff, M. (2013) The age of the Nördlinger Ries impact crater (Germany) - an overview and brief discussion of the new isotopic ages for the Ries impact. German J Geol 164: 433-445.

Buchner, E., Hölzel, M., Schmieder, M., Ferrière, L., Koeberl, C., Rasser, M., Fietzke, J., Frische, M., Meier, M. M. M., Busemann, H., Maden, C., and Kutterolf, S. (2018). The meteorite from Steinheim, SW Germany: probably a pallasite. 81st Annual Meeting of the Meteoritical Society (held 22-27 July 2018 in Moscow, Russia), LPI Contribution No. 2067, abstract no. 6055. Lunar and Planetary Institute, Houston, TX.

Buchwald, V.F. (1973) The pallasite Imilac, Chile. Meteoritics 8:333-334.

Burgess, S.D., Muirhead, J.D., and Bowring, S.A. (2017) Initial pulse of Siberian Traps sills as the trigger of the end-Permian mass extinction. Nat Commun 8:164.

Buschbach, T.C. and Ryan, R. (1963) Ordovician explosion structure at Glasford, Illinois. AAPG Bull 47:2015-2022.

Byerly, G.R., Lowe, D.R., Wooden, J.L., and Xie, X. (2002) An Archean impact layer from the Pilbara and Kaapvaal cratons. Science 297:1325-1327.

Cannon, W.F., Schulz, K.J., Horton, J.W., and Kring, D.A. (2010) The Sudbury impact layer in the Paleoproterozoic iron ranges of northern Michigan, USA. GSA Bull 122:50-75.

Canup, R.M. and Asphaug, E. (2001) Origin of the Moon in a giant impact near the end of the Earth's formation. Nature 412:708-712.

Cavosie, A.J. (2018) The enduring mystery of Australasian Tektites. Elements 14:212-213.

Chabou, M.C. (2019) Meteorite impact structures in the Arab World: an overview. In The Geology of the Arab World-An Overview, edited by A. Bendaoud, Z. Hamimi, M. Hamoudi, S. Djemai, and B. Zoheir, Springer, Cham, Switzerland, pp 455-506.

Chen, M., Koeberl, C., Xiao, W., Xie, X., and Tan, D. (2011) Planar deformation features in quartz from impact-produced polymict breccia of the Xiuyan crater, China. Meteorit Planet Sci 46:729-736.

Chennaoui Aoudjehane, H., El Kerni, H., Reimold, W.U., Baratoux, D., Koeberl, C., Bouley, S., and Aoudjehane, M. (2016) The Agoudal (High Atlas Mountains, Morocco) shatter cone conundrum: a recent meteorite fall onto the remnant of an impact site. Meteorit Planet Sci 51:14971518.

Cione, A.L., Tonni, E.P., San Cristóbal, J., Hernández, P.J., Benítez, A., Bordignon, F., and Perí, J.A. (2002) Putative meteoritic craters in Río Cuarto (Central Argentina) interpreted as eolian structures. Earth Moon Planets 91:9-24.
Claeys, P.H. and Goderis, S. (2007) Solar system: lethal billiards. Nature 449:30-31.

Claeys, P.H., Casier, J.G., and Margolis, S.V. (1992) Microtektites and mass extinctions: evidence for a Late Devonian asteroid impact. Science 257:1102-1104.

Claeys, P.H., Kiessling, W., and Alvarez, W. (2002) Distribution of Chicxulub ejecta at the Cretaceous-Tertiary boundary. In Catastrophic Events and Mass Extinctions: Impacts and Beyond, GSA Special Paper 356, edited by C. Koeberl and K.G. MacLeod, Geological Society of America, Boulder, CO, pp 55-68.

Classen, J. (1977) Catalogue of 230 certain, probable, possible, and doubtful impact structures. Meteoritics 12:61-78.

Clutson, M.J., Brown, D.E., and Tanner, L.H. (2018) Distal processes and effects of multiple Late Triassic terrestrial bolide impacts: insights from the Norian Manicouagan event, northeastern Quebec, Canada. In The Late Triassic World, edited by L.H. Tanner, Springer, Cham, Switzerland, pp 127187.

Clyde, W.C., Ramezani, J., Johnson, K.R., Bowring, S.A., and Jones, M.M. (2016) Direct high-precision U-Pb geochronology of the end-Cretaceous extinction and calibration of Paleocene astronomical timescales. Earth Planet Sci Lett 452:272-280.

Cockell, C.S. (2006) The origin and emergence of life under impact bombardment. Phil Trans R Soc B 361:1845-1856.

Cockell, C.S. and Lee, P. (2002) The biology of impact craters-a review: Biol Rev 77:279-310.

Cockell, C.S., Osinski, G.R., and Lee, P. (2003) The impact crater as a habitat: effects of impact processing of target materials. Astrobiology 3:181-191.

Cohen, B.E., Mark, D.F., Lee, M.R., and Simpson, S.L. (2017) A new high-precision ${ }^{40} \mathrm{Ar} /{ }^{39} \mathrm{Ar}$ age for the Rochechouart impact structure: at least $5 \mathrm{Ma}$ older than the TriassicJurassic boundary. Meteorit Planet Sci 52:1600-1611.

Cohen, K.M., Finney, S.C., Gibbard, P.L., and Fan, J.-X. (2013) The ICS International Chronostratigraphic Chart, v. 2018/08. Episodes 36:199-204.

Consolmagno, G.J. and Britt, D.T. (1998) The density and porosity of meteorites from the Vatican collection. Meteorit Planet Sci 33:1231-1241.

Consolmagno, G.J., Britt, D.T., and Macke, R.J. (2008) The significance of meteorite density and porosity. Geochemistry 68:1-29.

Cordua, W.S. (1985) Rock Elm structure, Pierce county, Wisconsin: a possible cryptoexplosion structure. Geology $13: 372-374$

Corfu, F. (2013) A century of U-Pb geochronology: the long quest towards concordance. GSA Bull 125:33-47.

Corfu, F. and Lightfoot, P.C. (1996) U-Pb geochronology of the sublayer environment, Sudbury Igneous Complex, Ontario. Econ Geol 91:1263-1269.

Cox, M.A., Cavosie, A.J., Ferrière, L., Timms, N.E., Bland, P.A., Miljković, K., Erickson, T.M., and Hess, B. (2019) Shocked quartz in polymict impact breccia from the Upper Cretaceous Yallalie impact structure in Western Australia. Meteorit Planet Sci 54:621-637.

Crawford, D.A., Boslough, M.B., Trucano, T.G., and Robinson, A.C. (1994) The impact of comet Shoemaker-Levy 9 on Jupiter. Shock Waves 4:47-50.

Crósta, A.P., Reimold, W.U., and Vasconcelos, M.A.R. (2019a) Cerro do Jarau and São Miguel do Tapuio: two newly confirmed, large impact structures in Brazil [abstract 3042]. In 
Lunar and Planetary Science L. LPI Contribution No. 2132. Lunar and Planetary Institute, Houston, TX.

Crósta, A.P., Reimold, W.U., Vasconcelos, M.A.R., Hauser, N., Oliveira, G.J.G., Maziviero, M.V., and Góes, A.M. (2019b) Impact cratering: The South American record-part 1. Geochemistry 79:1-61.

Crósta, A.P., Reimold, W.U., Vasconcelos, M.A.R., Hauser, N., Oliveira, G.J.G., Maziviero, M.V., and Góes, A.M. (2019c) Impact cratering: The South American record-part 2. Geochemistry 79:191-220.

Crow, C.A., McKeegan, K.D., and Moser, D.E. (2017) Coordinated $\mathrm{U}-\mathrm{Pb}$ geochronology, trace element, Ti-in-zircon thermometry and microstructural analysis of Apollo zircons. Geochim Cosmochim Acta 202:264-284.

Daly, R.T., Schultz, P.H., Lassiter, J.C., Loewy, S.W., Thompson, L.M., and Spray, J.G. (2018) Contrasting meteoritic signatures within the Clearwater East and Clearwater West impact structures: the view from osmium isotopes. Geochim Cosmochim Acta 235:262-284.

Darlington, V., Blenkinsop, T., Dirks, P., Salisbury, J., and Tomkins, A. (2016) The Lawn Hill annulus: n Ordovician meteorite impact into water-saturated dolomite. Meteorit Planet Sci 51:2416-2440.

Davies, J.H.F.L., Marzoli, A., Bertrand, H., Youbi, N., Ernesto, M., and Schaltegger, U. (2017) End-Triassic mass extinction started by intrusive CAMP activity. Nat Commun 8:15596.

Davis, D.W. (2008) Sub-million-year age resolution of Precambrian igneous events by thermal extraction-thermal ionization mass spectrometer $\mathrm{Pb}$ dating of zircon: application to crystallization of the Sudbury impact melt sheet. Geology 36: 383-386.

Davis, M., Hut, P., and Muller, R.A. (1984) Extinction of species by periodic comet showers. Nature 308:715-717.

Deino, A.L., Becker, T.A., and Garvin, J.B. (1990) Laserfusion ${ }^{40} \mathrm{Ar} /{ }^{39} \mathrm{Ar}$ ages of acid zhamanshinite. In Lunar Planet Sci XXI, Houston, TX, pp 271-272.

Dence, M.R. (1971) Impact melts. J Geophys Res 76:55525565.

Dence, M.R., Innes, M.J.S., and Beals, C.S. (1965) On the probable meteorite origin of the Clearwater Lakes, Quebec. $J$ R Astron Soc Canada 59:13-22.

DePalma, R.A., Smit, J., Burnham, D.A., Kuiper, K., Manning, P.L., Oleinik, A., Larson, P., Maurrasse, F.J., Vellekoop, J., Richards, M.A., and Gurche, L. (2019) A seismically induced onshore surge deposit at the KPg boundary, North Dakota. Proc Natl Acad Sci U S A 116:8190-8199.

Deutsch, A. and Koeberl, C. (2006) Establishing the link between the Chesapeake Bay impact structure and the North American tektite strewn field: the $\mathrm{Sr}-\mathrm{Nd}$ isotopic evidence. Meteorit Planet Sci 41:689-703.

Deutsch, A. and Schärer, U. (1994) Dating terrestrial impact events. Meteoritics 29:301-322.

Deutsch, A., Buhl, D., and Langenhorst, F. (1992) On the significance of crater ages: new ages for Dellen (Sweden) and Araguainha (Brazil). Tectonophys 216:205-218.

D'Hondt, S., Pilson, M.E., Sigurdsson, H., Hanson Jr, A.K., and Carey, S. (1994) Surface-water acidification and extinction at the Cretaceous-Tertiary boundary. Geology 22:983-986.

Dressler, B.O. and Reimold, W.U. (2001) Terrestrial impact melt rocks and glasses. Earth Sci Rev 56:205-284.

Durda, D.D. and Kring, D.A. (2004) Ignition threshold for impact-generated fires. J Geophys Res Planets 109:E08004.

Durda, D.D., Greenberg, R., and Jedicke, R. (1998) Collisional models and scaling laws: a new interpretation of the shape of the main-belt asteroid size distribution. Icarus 135: 431-440.

Dypvik, H., Gudlaugsson, S.T., Tsikalas, F., Attrep, M., Jr., Ferrell, R.E., Jr., Krinsley, D.H., Mørk, A., Faleide, J.I., and Nagy, J. (1996) Mjølnir structure: an impact crater in the Barents Sea. Geology 24:779-782.

Earth Impact Database. (2018) Online Resource. University of New Brunswick, Fredericton, Canada. Available online at www.passc.net/EarthImpactDatabase/New\%20website_052018/Index.html (accessed April 6, 2019).

Elo, S., Kuivasaari, T., Lehtinen, M., Sarapää, O., and Uutela, A. (1993) Iso-Naakkima, a circular structure filled with Neoproterozoic sediments, Pieksämäki, southeastern Finland. Bull Geol Soc Finland 65:3-30.

Emrich, G.H. and Bergstrom, R.E. (1962) Des Plaines disturbance, Northeastern Illinois. GSA Bull 73:959-968.

Englund, K.J. and Roen, J.B. (1963) Origin of the Middlesnoro Basin, Kentucky. USGS Prof Pap 450:E20-E22.

Erickson, T.M., Timms, N.E., Kirkland, C.L., Tohver, E., Cavosie, A.J., Pearce, M.A., and Reddy, S.M. (2017) Shocked monazite chronometry: integrating microstructural and in situ isotopic age data for determining precise impact ages. Contrib Mineral Petrol 172:11.

Erickson, T.M., Kirkland, C.L., Timms, N.E., Cavosie, A.J., and Davison T.M. (June 10-13, 2019a) The Yarrabubba impact structure, Western Australia; an environmental savior during Paleoproterozoic Snowball Earth? In Abstract presented at the "Impacts and Their Role in the Evolution of Life" Conference, Tällberg, Sweden.

Erickson, T.M., Kirkland, C.L., Timms, N.E., Cavosie, A.J., and Davison T.M. (September 30 to October 1, 2019b) Shocked zircon and monazite ages establish Yarrabubba, Western Australia, as the Earth's oldest preserved impact structure [abstract 5107]. In Large Meteorite Impacts VI 2019, Brasília, Brazil. LPI Contribution No. 2136.

Ernst, R.E. and Youbi, N. (2017) How Large Igneous Provinces affect global climate, sometimes cause mass extinctions, and represent natural markers in the geological record. Palaeogeogr Palaeoclimatol Palaeoecol 478:30-52.

Erwin, D.H., Bowring, S.A., and Yugan, J. (2002) End-Permian mass extinctions: a review. In Catastrophic Events and Mass Extinctions: Impacts and Beyond, GSA Special Paper 356, edited by C. Koeberl and K.G. MacLeod, Geological Society of America, Boulder, CO, pp 363-384.

Evans, N.J., Gregoire, D.C., and Goodfellow, W.D. (1993). Use of platinum-group elements for impactor identification: Terrestrial impact craters and Cretaceous-Tertiary boundary. Geochim Cosmochim Acta 57:3737-3748.

Farley, K.A. (1995) Cenozoic variations in the flux of interplanetary dust recorded by ${ }^{3} \mathrm{He}$ in a deep-sea sediment. Nature 376:153-156.

Farley, K.A. (2001) Extraterrestrial helium in seafloor sediments: identification, characteristics, and accretion rate over geologic time. In Accretion of Extraterrestrial matter throughout Earth's History, edited by B. Peucker-Ehrenbrink and B. Schmitz, Springer, Boston, MA, pp 197-204.

Farley, K.A. (2002) (U-Th)/He dating: techniques, calibrations, and applications. In Noble Gases in Geochemistry and Cosmochemistry, edited by D. Porcelli, C.J. Ballentine, and R. Wieler, Reviews in Mineralogy and Geochemistry, Vol. 47, Mineralogical Society of America, Washington, DC, pp 819-844.

Farley, K.A. and Stockli, D.F. (2002) (U-Th)/He dating of phosphates: apatite, monazite, and xenotime. In Phosphates: 
Geochemical, Geobiological and Materials Importance, edited by M.J. Kohn, J. Rakovan, and J.M. Hughes, Reviews in Mineralogy and Geochemistry, Vol. 48, Mineralogical Society of America, Washington, D.C., pp 559-577.

Farley, K.A., Montanari, A., Shoemaker, E.M., and Shoemaker, C.S. (1998) Geochemical evidence for a comet shower in the late Eocene. Science 280:1250-1253.

Farley, K.A., Vokrouhlický, D., Bottke, W.F., and Nesvorný, D. (2006) A late Miocene dust shower from the break-up of an asteroid in the main belt. Nature 439:295-297.

Ferrière, L. and Osinski, G.R. (2012) Shock metamorphism. In Impact Cratering: Processes and Products, edited by G.R. Osinski and E. Pierazzo, Wiley-Blackwell, Chichester, pp 106-124.

Ferrière, L., Lubala, F.R., Osinski, G.R., and Kaseti, P.K. (2011) The newly confirmed Luizi impact structure, Democratic Republic of Congo-insights into central uplift formation and post-impact erosion. Geology 39:851-854.

Ferrière, L., Barrat, J.A., Giuli, G., Koeberl, C., Schulz, T., Topa, D., and Wegner, W. (2017) A new tektite strewn field discovered in Uruguay [abstract 6195]. In 80th Annual Meeting of the Meteoritical Society. LPI Contribution No. 1987. Lunar and Planetary Institute, Houston TX.

Flamini, E., Di Martino, M., and Coletta, A., editors. (2019) Encyclopedic Atlas of Terrestrial Impact Craters. Springer, Switzerland, $606 \mathrm{p}$.

Fletcher, I.R. and McNaughton N.J. (2002) Chapter 6.1Granitoid geochronology: SHRIMP zircon and titanite data. In AMIRA P482 Final Report, edited by D.C. Champion and K.F. Cassidy, Springer, Cham, Switzerland, pp 6.101-6.102.

Floran, R.J., Grieve, R.A.F., Phinney, W.C., Warner, J.L., Simonds, C.H., Blanchard, D.P., and Dence, M.R. (1978) Manicouagan impact melt, Quebec, 1, stratigraphy, petrology, and chemistry. J Geophys Res Solid Earth 83:27372759.

Folco, L., Glass, B.P., D’Orazio, M., and Rochette, P. (2018) Australasian microtektites: impactor identification using Cr, Co and Ni ratios. Geochim Cosmochim Acta 222:550 568.

Ford, J.H. (2015) The Tennessee meteorite impact sites and changing perspectives on impact cratering. Doctoral thesis, University of Southern Queensland, Australia, Toowoomba, Queensland, Australia, 268 p.

Ford, J.R.H., Orchiston, W., and Clendening, R. (2012) The Wells Creek meteorite impact site and changing views on impact cratering. J Astronom Hist Herit 15:159-178.

Frederichs, T., Bleil, U., Gersonde, R., and Kuhn, G. (2002) Revised age of the Eltanin impact in Southern Ocean. EOS Trans Am Geophys Union 83(47), Fall Meet. Suppl., Abstract OS22C-028.

Freeberg, J.H. (1969) Terrestrial impact structures: a bibliography, 1965-68. USGS Bull 1320:1-39.

French, B.M. (1998) Traces of Catastrophe: A Handbook of Shock-Metamorphic Effects in Terrestrial Meteorite Impact Structures. Lunar and Planetary Institute, Houston TX, Mineralogical Society of America, Chantilly, Virginia, 120 p. LPI Contribution No. 954.

French, B.M. (2004) The importance of being cratered: the new role of meteorite impact as a normal geological process. Meteorit Planet Sci 39:169-197.

French, B.M. and Koeberl, C. (2010) The convincing identification of terrestrial meteorite impact structures: what works, what doesn't, and why. Earth Sci Rev 98:123-170.
French, B.M., Cordua, W.S., and Plescia, J.B. (2004) The Rock Elm meteorite impact structure, Wisconsin: geology and shock-metamorphic effects in quartz. GSA Bull 116:200-218.

French, B.M., McKay, R.M., Liu, H.P., Briggs, D.E., and Witzke, B.J. (2018) The Decorah structure, northeastern Iowa: geology and evidence for formation by meteorite impact. GSA Bull 130:2062-2086.

Fudali, R.F. and Cressy, P.J. (1976) Investigation of a new stony meteorite from Mauritania with some additional data on its find site: aouelloul crater. Earth Planet Sci Lett 30: 262-268.

Ganapathy, R. (1980) A major meteorite impact on the earth 65 million years ago: evidence from the Cretaceous-Tertiary boundary clay. Science 209:921-923.

Gentner, W., Kleinmann, B., and Wagner, G.A. (1967) New KAr and fission track ages of impact glasses and tektites. Earth Planet Sci Lett 2:83-86.

Gentner, W., Storzer, D., and Wagner, G.A. (1969) New fission track ages of tektites and related glasses. Geochim Cosmochim Acta 33:1075-1081.

Gersonde, R., Kyte, F.T., Bleil, U., Diekmann, B., Flores, J.A., Gohl, K., Grahl, G., Hagen, R., Kuhn, G., Sierro, F.J., and Völker, D. (1997) Geological record and reconstruction of the late Pliocene impact of the Eltanin asteroid in the Southern Ocean. Nature 390:357-363.

Glass, B.P. and Simonson, B.M. (2012) Distal impact ejecta layers: spherules and more. In Impact!, edited by F. Jourdan and W.U. Reimold, Mineralogical Society of America, Chantilly, Virginia. Elements Vol. 8, pp 43-48.

Glass, B.P. and Simonson, B.M. (2013) Distal Impact Ejecta Layers: A Record of Large Impacts in Sedimentary Deposits. Springer, Berlin, Heidelberg, 716 p.

Glass, B.P., Burns, C.A., Crosbie, J.R., and DuBois, D.L. (1985) Late Eocene North American microtektites and clinopyroxene-bearing spherules. J Geophys Res Solid Earth 90:175-196.

Glikson, A.Y., Hickman, A.H., and Vickers, J. (2008) Hickman Crater, Ophthalmia Range, Western Australia: evidence supporting a meteorite impact origin. Aust J Earth Sci 55: 1107-1117.

Glikson, A., Hickman, A., and Crossley, R. (2016a) Evidence for a shock-metamorphic breccia within a buried impact crater, Lake Raeside, Yilgarn Craton, Western Australia. Aust J Earth Sci 63:99-109.

Glikson, A., Hickman, A., Evans, N.J., Kirkland, C.L., Park, J.W., Rapp, R., and Romano, S. (2016b) A new 3.46 Ga asteroid impact ejecta unit at Marble Bar, Pilbara Craton, Western Australia: a petrological, microprobe and laser ablation ICP-MS study. Precambr Res 279:103-122.

Goderis, S., Kalleson, E., Tagle, R., Dypvik, H., Schmitt, R.T., Erzinger, J., and Claeys, P. (2009). A non-magmatic iron projectile for the Gardnos impact event. Chemical Geology 258:145-156.

Goderis, S., Hertogen, J., Vanhaecke, F., Claeys, P., Gibson, R.L., and Reimold, W.U. (2010) Siderophile elements from the Eyreville drill cores of the Chesapeake Bay impact structure do not constrain the nature of the projectile. In Large Meteorite Impacts and Planetary Evolution IV, GSA Special Paper 465, edited by R.L. Gibson and W.U. Reimold, Geological Society of America, Boulder, CO, pp 395-409.

Goderis, S., Paquay, F., and Claeys, P.H. (2012) Projectile identification in terrestrial impact structures and ejecta material. In Impact Cratering: Processes and Products, edited 
by G.R. Osinski and E. Pierazzo, Wiley-Blackwell, John Wiley \& Sons, Hoboken, New Jersey, pp 223-239.

Goderis, S., Tagle, R., Belza, J., Smit, J., Montanari, A., Vanhaecke, F., Erzinger, J., and Claeys, P.H. (2013) Reevaluation of siderophile element abundances and ratios across the Cretaceous-Paleogene (K-Pg) boundary: implications for the nature of the projectile. Geochim Cosmochim Acta 120: 417-446.

Goderis, S., Tagle, R., Fritz, J., Bartoschewitz, R., and Artemieva, N. (2017) On the nature of the Ni-rich component in splash-form Australasian tektites. Geochim Cosmochim Acta 217:28-50.

Grahn, Y. (1997) Chitinozoan biostratigraphy of the early Caradocian Lockne impact structure, Jämtland, Sweden. Meteorit Planet Sci 32:745-751.

Grahn, Y. and Ormö, J. (1995) Microfossil dating of the Brent meteorite crater, southeast Ontario, Canada. Rev Micropaléont 38:131-137.

Grahn, Y., Nõlvak, J., and Paris, F. (1996) Precise chitinozoan dating of Ordovician impact events in Baltoscandia. $J \mathrm{Mi}$ cropalaeontol 15:21-35.

Grant, J.A., Koeberl, C., Reimold, W.U., and Schultz, P.H. (1997) Gradation of the Roter Kamm impact crater, Namibia. J Geophys Res Planets 102:16327-16338.

Grey, K., Walter, M.R., and Calver, C.R. (2003) Neoproterozoic biotic diversification: Snowball Earth or aftermath of the Acraman impact? Geology 31:459-462.

Grier, J.A., McEwen, A.S., Lucey, P.G., Milazzo, M., and Strom, R.G. (2001) Optical maturity of ejecta from large rayed lunar craters. J Geophys Res Planets 106:32847-32862.

Grieve, R.A.F. (1978) The melt rocks at Brent crater, Ontario, Canada. Proc Lunar Planet Sci Conf 9:2579-2608.

Grieve, R.A.F. (1980) Impact bombardment and its role in proto-continental growth on the early Earth. Precambr Res 10:217-247.

Grieve, R.A.F. (1984) The impact cratering rate in recent time. J Geophys Res Solid Earth 89:B403-B408.

Grieve, R.A.F. (1987) Terrestrial impact structures. Ann Rev Earth Planet Sci 15:245-270.

Grieve, R.A.F. (1991) Terrestrial impact: the record in the rocks. Meteoritics 26:175-194.

Grieve, R.A.F. (2001a) The terrestrial cratering record. In Accretion of Extraterrestrial Matter Throughout Earth's History, edited by B. Peucker-Ehrenbrink and B. Schmitz, Springer, Boston, MA, pp 379-402.

Grieve, R.A.F. (2001b) lmpact cratering on Earth. In A Synthesis of Geological Hazards in Canada, edited by G.R. Brooks, Geological Survey of Canada Bulletin, Vol. 548, Geological Survey of Canada, Ottawa, pp 207-224.

Grieve, R.A.F. (2006) Impact Structures in Canada. Geological Association of Canada, GEOtext 5, St. John's, 120 p.

Grieve, R. and Therriault, A. (2000) Vredefort, Sudbury, Chicxulub: three of a kind? Ann Rev Earth Planet Sci 28: 305-338.

Grieve, R.A.F. and Cintala, M.J. (1992) An analysis of differential impact melt-crater scaling and implications for the terrestrial impact record. Meteoritics 27:526-538.

Grieve, R.A.F. and Dence, M.R. (1979) The terrestrial cratering record: II. The crater production rate. Icarus 38:230-242.

Grieve, R.A.F. and Kring, D.A. (2007) The geologic record of destructive impact events on Earth. In Comet/Asteroid Impacts and Human Society, edited by P. Bobrowsky and $\mathrm{H}$. Rickman, Springer, Berlin, Heidelberg, pp 3-24.
Grieve, R.A.F. and Pesonen, L.J. (1996) Terrestrial impact craters: their spatial and temporal distribution and impacting bodies. In Worlds in Interaction: Small Bodies and Planets of the Solar System, edited by H. Rickman and M. Valtonen, Springer, Dordrecht, pp 357-376.

Grieve, R.A.F. and Robertson, P.B. (1979) The terrestrial cratering record: I. current status of observations. Icarus 38: 212-229.

Grieve R.A.F. and Shoemaker E.M. (1994) The record of past impacts on Earth. In Hazards due to Comets and Asteroids, Space Science Series, edited by T. Gehrels, M.S. Matthews, and A. Schumann, University of Arizona Press, Tucson, AZ, pp 417-462.

Grieve, R.A.F. and Therriault, A.M. (2012) Impactites: their characteristics and spatial distribution. In Impact Cratering: Processes and Products, edited by G.R. Osinski and E. Pierazzo, Wiley-Blackwell, Chichester, pp 90-105.

Grieve, R.A.F., Robertson, P.B., and Dence, M.R. (1981) Constraints on the formation of ring impact structures, based on terrestrial data. In Multi-Ring Basins: Formation and Evolution, edited by R.B. Merrill and P.H. Schultz, Pergamon Press, New York, Oxford, pp 37-57.

Grieve, R.A.F., Sharpton, V.L., Rupert, J.D., and Goodacre, A.K. (1988) Detecting a periodic signal in the terrestrial cratering record. Proc Lunar Planet Sci Conf 18:375-382.

Grieve, R.A.F., Bottomley, R.B., Bouchard, M.A., Robertson, P.B., Orth, C.J., and Attrep, M, Jr. (1991) Impact melt rocks from New Quebec Crater, Quebec, Canada. Meteoritics 26:31-39.

Grieve, R.A., Cintala, M.J., and Therriault, A.M. (2006) Large-scale impacts and the evolution of the Earth's crust: the early years. In Processes on the Early Earth, GSA Special Paper 405, edited by W.U. Reimold and R.L. Gibson, Geological Society of America, Boulder, CO, pp 23-31.

Grieve, R.A.F., Morgan, J.V., and Artemieva, N. (2010) The evolution of the Onaping Formation at the Sudbury impact structure. Meteorit Planet Sci 45:759-782.

Grimm, R.E. and Marchi, S. (2018) Direct thermal effects of the Hadean bombardment did not limit early subsurface habitability. Earth Planet Sci Lett 485:1-8.

Grolier, M.J. (1985) Bibliography of terrestrial impact structures. NASA Report 19860002234, 532 p.

Gurov, E.P. and Gurova, E.P. (1998) The group of Macha craters in western Yakutia. Planet Space Sci 46:323-328.

Gurov, E.P., Gurova, E.P., and Kovaliukh, N.N. (1987) The group of Macha meteorite craters in western Iakutiia. Akademiia Nauk SSSR Doklady 296:185-188.

Gurov, E.P., Gurova, H.P., Rakitskaya, R.B., and Yamnichenko, A.Y. (1993) The Karakul depression in Pamirs: the first impact structure in Central Asia. Lunar and Planetary Science XXIV, Lunar and Planetary Institute, Houston, TX, pp 591592.

Gurov, E.P., Gurova, E.P., and Sokur, T.M. (2002) Geology and Petrography of the Zapadnaya impact crater in the Ukrainian Shield. In Impacts in Precambrian Shields, edited by J. Plado and L.J. Pesonen, Springer, Berlin, Heidelberg, pp 173-188.

Gurov, E., Gurova, E., Chernenko, Y., and Yamnichenko, A. (2009) The Obolon impact structure, Ukraine, and its ejecta deposits. Meteorit Planet Sci 44:389-404.

Gurov, E., Nikolaenko, N., Shevchuk, H., and Yamnichenko, A. (2017) Kamenetsk-a new impact structure in the Ukrainian Shield. Meteorit Planet Sci 52:2461-2469.

Haines, P.W. (2005) Impact cratering and distal ejecta: the Australian record. Aust J Earth Sci 52:481-507. 
Haines, P.W. (2014) Collaborative scientific drilling at Hickman Crater. GSWA extended abstracts, GSWA Seminar (2014, Fremantle, WA), Geological Survey of Western Australia, East Perth, Western Australia, pp 1-4.

Haines, P.W. and Rawlings, D.J. (2002) The Foelsche structure, Northern Territory, Australia: an impact crater of probable Neoproterozoic age. Meteorit Planet Sci 37:269-280.

Haines, P.W., Jenkins, R.J., and Kelley, S.P. (2001) Pleistocene glass in the Australian desert: the case for an impact origin. Geology 29:899-902.

Haines, P.W., Sweet, I.P., and Mitchell, K. (August 12-17, 2012) Cleanskin structure, Northern Territory and Queensland, Australia: evidence for an impact origin [abstract 5176]. In 75th Annual Meeting of the Meteoritical Society, Cairns, Australia, Supplement to Meteoritics \& Planetery Science.

Hallam, A. and Wignall, P.B. (1997) Mass Extinctions and Their Aftermath. Oxford University Press, Oxford, 328 p.

Hargraves, R.B., Kellogg, K.S., Fiske, P.S., and Hougen, S.B. (1994) Allochthonous impact-shocked rocks and superimposed deformations at the Beaverhead site in southwest Montana. In Large Meteorite Impacts and Planetary Evolution, GSA Special Paper 293, edited by B.O. Dressler, R.A.F. Grieve, and V.L. Sharpton, Geological Society of America, Boulder, CO, pp 225-236.

Hart, R.J., Andreoli, M.A., Tredoux, M., Moser, D., Ashwal, L.D., Eide, E.A., Webb, S.J., and Brandt, D. (1997) Late Jurassic age for the Morokweng impact structure, southern Africa. Earth Planet Sci Lett 147:25-35.

Hartmann, W.K. and Neukum, G. (2001) Cratering chronology and the evolution of Mars. In Chronology and evolution of Mars, edited by R. Kallenbach, J. Geiss, and W.K. Hartmann, Springer, Dordrecht, pp 165-194.

Hartung, J. and Koeberl, C. (1994) In search of the Australasian tektite source crater: the Tonle Sap hypothesis. Meteoritics 29:411-416.

Hassler, S.W., Simonson, B.M., Sumner, D.Y., and Bodin, L. (2011) Paraburdoo spherule layer (Hamersley Basin, Western Australia): distal ejecta from a fourth large impact near the Archean-Proterozoic boundary. Geology 39:307-310.

Hauser, N., Reimold, W.U., Cavosie, A.J., Crósta, A.P., Schwarz, W.H., Trieloff, M., Da Silva Maia de Souza, C., Pereira, L.A., Rodrigues, E.N., and Brown, M. (2019) Linking shock textures revealed by BSE, CL, and EBSD with $\mathrm{U}-\mathrm{Pb}$ data (LA-ICP-MS and SIMS) from zircon from the Araguainha impact structure, Brazil. Meteorit Planet Sci 54: 2286-2311. DOI: 10.1111/maps.13371.

Hecht, L., Reimold, W.U., Sherlock, S., Tagle, R., Koeberl, C., and Schmitt, R.T. (2008) New impact-melt rock from the Roter Kamm impact structure, Namibia: further constraints on impact age, melt rock chemistry, and projectile composition. Meteorit Planet Sci 43:1201-1218.

Heck, P.R., Schmitz, B., Baur, H., Halliday, A.N., and Wieler, R. (2004) Fast delivery of meteorites to Earth after a major asteroid collision. Nature 430:323-325.

Heisler, J. and Tremaine, S. (1989) How dating uncertainties affect the detection of periodicity in extinctions and craters. Icarus 77:213-219.

Heizmann, E.P.J. and Hesse, A. (1995) [The Middle Miocene bird and mammal faunae of the Nördlinger Ries (MN 6) and the Steinheim Basin (MN 7) A comparison]. Cour. Forsch Inst Senckenb 181:171-185.

Herd, C.D.K., Froese, D.G., Walton, E.L., Kofman, R.S., Herd, E.P.K., and Duke, M.J.M. (2008) Anatomy of a young impact event in central Alberta, Canada: prospects for the missing Holocene impact record. Geology 36:955-958.

Hergarten, S. and Kenkmann, T. (2015) The number of impact craters on Earth: any room for further discoveries? Earth Planet Sci Lett 425:187-192.

Heri, A.R., Robyr, M., and Villa, I.M. (2014) Petrology and geochronology of "muscovite age standard" B4M. In $A d$ vances in ${ }^{40} \mathrm{Ar}{ }^{39} \mathrm{Ar}$ dating: From Archaeology to Planetary Sciences, edited by F. Jourdan, D.F. Mark, and C. Verati, Geological Society of London Special Publications Vol. 378, Geological Society, London, UK, pp 69-78.

Hesselbo, S.P., McRoberts, C.A., and Pálfy, J. (2007) TriassicJurassic boundary events: problems, progress, possibilities. Palaeogeogr Palaeoclimatol Palaeoecol 244:1-10.

Higgins, M. and Tait, L. (1990) A possible new impact structure near Lac de la Presqu 'île, Québec, Canada. Meteoritics 25: 235-236.

Hildebrand, A.R., Penfield, G.T., Kring, D.A., Pilkington, M., Camargo, Z.A., Jacobsen, S.B., and Boynton, W.V. (1991) Chicxulub crater: a possible Cretaceous/Tertiary boundary impact crater on the Yucatan Peninsula, Mexico. Geology 19: 867-871.

Hodych, J.P. and Dunning, G.R. (1992) Did the Manicouagan impact trigger end-of-Triassic mass extinction?. Geology 20: 51-54.

Holliday, V.T., Kring, D.A., Mayer, J.H., and Goble, R.J. (2005) Age and effects of the Odessa meteorite impact, western Texas, USA. Geology 33:945-948.

Holm-Alwmark, S., Alwmark, C., Ferrière, L., Lindström, S., Meier, M.M.M., Scherstén, A., Herrmann, M., Masaitis, V.L., Mashchak, M.S., Naumov, M.V., and Jourdan, F. (2019) An Early Jurassic age for the Puchezh-Katunki impact structure (Russia) based on ${ }^{40} \mathrm{Ar} /{ }^{39} \mathrm{Ar}$ data and palynology. Meteorit Planet Sci 54:1764-1780.

Honda, M., Caffee, M.W., Miura, Y.N., Nagai, H., Nagao, K., and Nishiizumi, K. (2002) Cosmogenic nuclides in the Brenham pallasite. Meteorit Planet Sci 37:1711-1728.

Hörz, F. (2000) Time-variable cratering rates? Science 288: 2095.

Hsü, K.J. (1980) Terrestrial catastrophe caused by cometary impact at the end of Cretaceous. Nature 285:201-203.

Huber, M.S., Črne, A.E., McDonald, I., Hecht, L., Melezhik, V.A., and Koeberl, C. (2014) Impact spherules from Karelia, Russia: possible ejecta from the $2.02 \mathrm{Ga}$ Vredefort impact event. Geology 42:375-378.

Huber, M.S., Koeberl, C., Smith, F.C., Glass, B.P., Mundil, R., and McDonald, I. (2019) Geochemistry of a confirmed Precambrian impact ejecta deposit: the Grænses $\varnothing$ spherule layer, South Greenland. Meteorit Planet Sci 54:2254-2272. DOI: doi.org/10.1111/maps.13271.

Hughen, K., Lehman, S., Southon, J., Overpeck, J., Marchal, O., Herring, C., and Turnbull, J. (2004) ${ }^{14} \mathrm{C}$ activity and global carbon cycle changes over the past 50,000 years. Science 303: 202-207.

Hughes, D.W. (2000) A new approach to the calculation of the cratering rate of the Earth over the last $125 \pm 20 \mathrm{Myr}$. Month Not Royal Astronom Soc 317:429-437.

Ivanov, B.A., Neukum, G., Bottke, W.F., and Hartmann, W.K. (2003) The comparison of size-frequency distributions of impact craters and asteroids and the planetary cratering rate. In Asteroids III, edited by W.F. Bottke, A. Cellino, P. Paolicchi, and R.P. Binzel, University of Arizona Press, Tucson, AZ, pp 89-101. 
Izett, G.A., Masaitis, V.L., Shoemaker, E.M., Dalrymple, G.B., and Steiner, M.B. (February 9-12, 1994) Eocene age of the Kamensk buried crater of Russia. In New Developments Regarding the KT Event and Other Catastrophes in Earth History Conference, Houston, TX, pp 55-56. LPI Contribution No. 825.

Izett, G.A., Cobban, W.A., Obradovich, J.D., and Dalrymple, G.B. (1998) ${ }^{40} \mathrm{Ar} /{ }^{39} \mathrm{Ar}$ age of the Manson impact structure, Iowa, and correlative impact ejecta in the Crow Creek Member of the Pierre Shale (Upper Cretaceous), South Dakota and Nebraska. GSA Bull 110:361-376.

Jansa, L.F., Pe-Piper, G., Robertson, P.B., and Friedenreich, O. (1989) Montagnais: a submarine impact structure on the Scotian Shelf, eastern Canada. GSA Bull 101:450-463.

Jessberger, E.K. (1988) ${ }^{40} \mathrm{Ar}-{ }^{39} \mathrm{Ar}$ dating of the Haughton impact structure. Meteoritics 23:233-234.

Jetsu, L. and Pelt, J. (2000) Spurious periods in the terrestrial impact crater record. Astronom Astrophys 353:409-418.

Johnson, B.C. and Bowling, T.J. (2014) Where have all the craters gone? Earth's bombardment history and the expected terrestrial cratering record. Geology 42:587-590.

Johnson, B.C. and Melosh, H.J. (2012) Impact spherules as a record of an ancient heavy bombardment of Earth. Nature 485:75-77.

Johnson, B.C., Collins, G.S., Minton, D.A., Bowling, T.J., Simonson, B.M., and Zuber, M.T. (2016) Spherule layers, crater scaling laws, and the population of ancient terrestrial impactors. Icarus 271:350-359.

Jolley, D., Gilmour, I., Gurov, E., Kelley, S., and Watson, J. (2010) Two large meteorite impacts at the CretaceousPaleogene boundary. Geology 38:835-838.

Jourdan, F. (2012) The ${ }^{40} \mathrm{Ar} /{ }^{39} \mathrm{Ar}$ dating technique applied to planetary sciences and terrestrial impacts. Aust J Earth Sci 59:199-224.

Jourdan, F. and Reimold, W.U. (August 12-17, 2012) Age of the Siljan impact structure [abstract 5093]. In 75th Meteoritical Society Conference, Cairns, Australia.

Jourdan, F., Renne, P.R., and Reimold, W.U. (2007) The problem of inherited ${ }^{40} \mathrm{Ar} *$ in dating impact glass by the ${ }^{40} \mathrm{Ar} /{ }^{39} \mathrm{Ar}$ method: evidence from the Tswaing impact crater (South Africa). Geochim Cosmochim Acta 71:1214-1231.

Jourdan, F., Renne, P.R., and Reimold, W.U. (2008) Highprecision ${ }^{40} \mathrm{Ar} /{ }^{39} \mathrm{Ar}$ age of the Jänisjärvi impact structure (Russia). Earth Planet Sci Lett 265:438-449.

Jourdan, F., Renne, P.R., and Reimold, W.U. (2009) An appraisal of the ages of terrestrial impact structures. Earth Planet Sci Lett 286:1-13.

Jourdan, F., Moynier, F., Koeberl, C., and Eroglu, S. (2011) ${ }^{40} \mathrm{Ar} /{ }^{39} \mathrm{Ar}$ age of the Lonar crater and consequence for the geochronology of planetary impacts. Geology 39:671-674.

Jourdan, F., Reimold, W.U., and Deutsch, A. (2012) Dating terrestrial impact structures. In Impact!, edited by F. Jourdan and W.U. Reimold, Elements, Vol. 8, Mineralogical Society of America, Chantilly, Virginia, pp 49-53.

Jourdan, F., Nomade, S., Wingate, M.T., Eroglu, E., and Deino, A. (2019) Ultraprecise age and formation temperature of the Australasian tektites constrained by ${ }^{40} \mathrm{Ar} /{ }^{39} \mathrm{Ar}$ analyses. $M e$ teorit Planet Sci 19. DOI: 10.1111/maps.13305. 54:25732591.

Kalleson, E., Corfu, F., and Dypvik, H. (2009) U-Pb systematics of zircon and titanite from the Gardnos impact structure, Norway: evidence for impact at $546 \mathrm{Ma}$ ? Geochim Cosmochim Acta 73:3077-3092.

Kamo, S.L., Reimold, W.U., Krogh, T.E., and Colliston, W.P. (1996) A $2.023 \mathrm{Ga}$ age for the Vredefort impact event and a first report of shock metamorphosed zircons in pseudotachylitic breccias and granophyre. Earth Planet Sci Lett 144:369-387.

Kastning, H. and Huntoon, P.W. (1996) Cluster of five small Pennsylvanian meteorite impact craters on Sheep Mountain near Douglas, Wyoming. In NASA's Wyoming Space Grant Fellowship Program 1995-6 Space Science Research: Graduate and Undergraduate Fellowship reports, edited by T.M. Ciardi and P.E. Johnson, University of Wyoming, Laramie, WY, pp 57-64.

Kaufmann, B. (2006) Calibrating the Devonian Time Scale: a synthesis of U-Pb ID-TIMS ages and conodont stratigraphy. Earth Sci Rev 76:175-190.

Kelley, S. (2002) K-Ar and Ar-Ar dating. In Noble Gases in Geochemistry and Cosmochemistry, edited by D. Porcelli, C.J. Ballentine, and R. Wieler, Reviews in Mineralogy and Geochemistry Vol. 47, Mineralogical Society of America, Washington, DC, pp 785-818.

Kelley, S. (2007) The geochronology of large igneous provinces, terrestrial impact craters, and their relationship to mass extinctions on Earth. J Geol Soc 164:923-936.

Kelley, S.P. and Gurov, E. (2002) Boltysh, another endCretaceous impact. Meteorit Planet Sci 37:1031-1043.

Kelley, S.P. and Spray, J.G. (1997) A late Triassic age for the Rochechouart impact structure, France. Meteorit Planet Sci 32:629-636.

Kenkmann, T. and Poelchau, M.H. (2009) Low-angle collision with Earth: the elliptical impact crater Matt Wilson, Northern Territory, Australia. Geology 37:459-462.

Kenkmann, T., Vasconcelos, M.A., Crosta, A.P., and Reimold, W.U. (2011) The complex impact structure Serra da Cangalha, Tocantins State, Brazil. Meteorit Planet Sci 46: 875-889.

Kenkmann, T., Collins, G.S., and Wünnemann, K. (2012) The modification stage of crater formation. In Impact Cratering: Processes and Products, edited by G.R. Osinski and E. Pierazzo, Wiley-Blackwell, Chichester, pp 60-75.

Kenkmann, T., Afifi, A.M., Stewart, S.A., Poelchau, M.H., Cook, D.J., and Neville, A.S. (2015) Saqqar: a $34 \mathrm{~km}$ diameter impact structure in Saudi Arabia. Meteorit Planet Sci 50: 1925-1940.

Kenkmann, T., Sundell, K.A., and Cook, D. (2018) Evidence for a large Paleozoic Impact Crater Strewn Field in the Rocky Mountains. Sci Rep 8:13246.

Kenkmann, T., Wulf, G., and Agarwal, A. (September 30 to October 1, 2019) India's third impact crater: Ramgarh, Rjasthan [abstract 5007]. In Large Meteorite Impacts VI 2019, Brasília, Brazil. LPI Contribution No. 2136.

Kenny, G.G., Crowley, J.L., Schmitz, M.D., Andreoli, M.A.G., and Gibson, R.L. (September 30 to October 1, 2019a) High-precision geochronology and thermal modeling of the Morokweng impact melt sheet, South Africa [abstract 5061]. In Large Meteorite Impacts VI 2019, Brasília, Brazil. LPI Contribution No. 2136.

Kenny, G.G., Schmieder, M., Whitehouse, M.J., Nemchin, A.A., Morales, L.F., Buchner, E., Bellucci, J.J., and Snape, J.F. (2019b) A new U-Pb age for shock-recrystallised zircon from the Lappajärvi impact crater, Finland, and implications for the accurate dating of impact events. Geochim Cosmochim Acta 245:479-494.

Khryanina, L.P. (1981) Sobolevskiy meteorite crater (SikhoteAlin' Range). Int Geol Rev 23:1-10.

King, D.T., Petruny, L.W., and Neathery, T.L. (2007) Ecosystem perturbation caused by a small Late Cretaceous marine impact, Gulf Coastal Plain, USA. In Large Ecosystem Perturbations: 
Causes and Consequences, GSA Special Paper 424, edited by S. Monechi, R. Coccioni, and M.R. Rampino, Geological Society of America, Boulder, CO, pp 97-107.

Kirkham, A. (2003) Glauconitic spherules from the Triassic of the Bristol area, SW England: probable microtektite pseudomorphs. Proc Geol Assoc 114:11-21.

Kjær, K.H., Larsen, N.K., Binder, T., Bjørk, A.A., Eisen, O., Fahnestock, M.A., Funder, S., Garde, A.A., Haack, H., Helm, V., and Houmark-Nielsen, M. (2018) A large impact crater beneath Hiawatha Glacier in northwest Greenland. Sci Adv 4: eaar8173.

Knoll, A., Walter, M., Narbonne, G., and Christie-Blick, N. (2006) The Ediacaran Period: a new addition to the geologic time scale. Lethaia 39:13-30.

Koeberl, C. (1997) Libyan Desert Glass: geochemical composition and origin. In Proceedings of the Silica '96, Pyramids, De Michele V, Segrate, Milan, Italy, pp 121-131.

Koeberl, C. (1998) Identification of meteoritic components in impactites. Geol Soc London Spec Pub 140:133-153.

Koeberl, C. (2006) Impact processes on the early Earth. In Early Earth, edited by J.W. Valley, Elements Vol. 2, Mineralogical Society of America, Chantilly, Virginia, pp 211-216.

Koeberl, C. (2009) Late Eocene impact craters and impactoclastic layers - an overview. In The Late Eocene EarthHothouse, Icehouse, and Impacts, GSA Special Paper 452, edited by C. Koeberl and A. Montanari, Geological Society of America, Boulder, CO, pp 17-26.

Koeberl, C. (2014) The geochemistry and cosmochemistry of impacts, In Treatise on Geochemistry, Vol. 2, edited by H.D. Holland and K.K. Turekian, Elsevier, Amsterdam, Netherlands; Heidelberg, Germany, pp 73-118.

Koeberl, C. and Ivanov, B.A. (2019) Asteroid impact effects on Snowball Earth. Meteorit Planet Sci 13. DOI: 10.1111/ maps.1329. Meteoritics \& Planetary Science 54:2273-2285.

Koeberl, C. and Reimold, W.U. (1995) The Newporte impact structure, North Dakota, USA. Geochim Cosmochim Acta 59: 4747-4767.

Koeberl, C., Hartung, J.B., Kunk, M.J., Klein, J., Matsuda, J.I., Nagao, K., Reimold, W.U., and Storzer, D. (1993) The age of the Roter Kamm impact crater, Namibia: constraints from ${ }^{40} \mathrm{Ar}-{ }^{39} \mathrm{Ar}, \mathrm{K}-\mathrm{Ar}, \mathrm{Rb}-\mathrm{Sr}$, fission track, and ${ }^{10} \mathrm{Be}-{ }^{26} \mathrm{Al}$ studies. Meteoritics 28:204-212.

Koeberl, C., Reimold, W.U., and Brandt, D. (1996) Red Wing Creek structure, North Dakota: petrographical and geochemical studies, and confirmation of impact origin. Meteorit Planet Sci 31:335-342.

Koeberl, C., Armstrong, R.A., and Reimold, W.U. (1997a) Morokweng, South Africa: a large impact structure of Jurassic-Cretaceous boundary age. Geology 25:731-734.

Koeberl, C., Bottomley, R., Glass, B.P., and Storzer, D. (1997b) Geochemistry and age of Ivory Coast tektites and microtektites. Geochim Cosmochim Acta 61:1745-1772.

Koeberl, C., Reimold, W.U., and Kelley, S.P. (2001) Petrography, geochemistry, and argon-40/argon-39 ages of impactmelt rocks and breccias from the Ames impact structure, Oklahoma: the Nicor Chestnut 18-4 drill core. Meteorit Planet Sci 36:651-669.

Koeberl, C., Reimold, W.U., Cooper, G., Cowan, D., and Vincent, P.M. (2005a) Aorounga and Gweni Fada impact structures, Chad: remote sensing, petrography, and geochemistry of target rocks. Meteorit Planet Sci 40:1455-1471.

Koeberl, C., Reimold, W.U., and Plescia, J. (2005b) BP and Oasis impact structures, Libya: remote sensing and field studies. In Impact Tectonics, edited by C. Koeberl and $\mathrm{H}$. Henkel, Springer, Berlin, Heidelberg, pp 161-190.

Koeberl, C., Shukolyukov, A., and Lugmair, G.W. (2007a) Chromium isotopic studies of terrestrial impact craters: identification of meteoritic components at Bosumtwi, Clearwater East, Lappajärvi, and Rochechouart. Earth Planet Sci Lett 256:534-546.

Koeberl, C., Ivanov, B.A., and Goodman, J. (2007b) Impact triggering of the Snowball Earth deglaciation? [abstract 8035]. In Bridging the Gap II: effect of Target Properties on the Impact Cratering Process, Lunar and Planetary Institute, Houston TX, pp 62-63. LPI Contribution No. 1360.

Koeberl, C., Crósta, A.P., and Schulz, T. (2019) Geochemical investigation of the Atacamaites, a new impact glass occurrence in South America [abstract 1255]. In Lunar and Planetary Science L. LPI Contribution No. 2132. Lunar and Planetary Institute, Houston TX.

Kohman, T.P. and Goel, P.S. (1963) Terrestrial ages of meteorites from cosmogenic C14. In Radioactive Dating, IAEA, Vienna, pp 395-411.

Kohn, B., Chung, L., and Gleadow, A. (2019) Fission-track analysis: field collection, sample preparation and data acquisition. In Fission-Track Thermochronology and Its Application to Geology, edited by M.G. Malusà and P.G. Fitzgerald, Springer, Cham, Switzerland, Lunar and Planetary Institute, Houston TX, pp 25-48.

Korochantseva, E.V., Trieloff, M., Lorenz, C.A., Buykin, A.I., Ivanova, M.A., Schwarz, W.H., Hopp, J., and Jessberger, E.K. (2007) L-chondrite asteroid breakup tied to Ordovician meteorite shower by multiple isochron ${ }^{40} \mathrm{Ar}-{ }^{39} \mathrm{Ar}$ dating. Meteorit Planet Sci 42:113-130.

Kriens, B.J., Shoemaker, E.M., and Herkenhoff, K.E. (1999) Geology of the Upheaval Dome impact structure, southeast Utah. J Geophys Res Planets 104:18867-18887.

Kring, D.A. (1995) The dimensions of the Chicxulub impact crater and impact melt sheet. J Geophys Res Planets 100: 16979-16986.

Kring, D.A. (2000) Impact events and their effect on the origin, evolution, and distribution of life. GSA Today 10:1-7.

Kring, D.A. (2002) Reevaluating the impact cratering kill curve. Meteorit Planet Sci 37:1648-1649.

Kring, D.A. (2003) Environmental consequences of impact cratering events as a function of ambient conditions on Earth. Astrobiology 3:133-152.

Kring, D.A. (2005) Hypervelocity collisions into continental crust composed of sediments and an underlying crystalline basement: comparing the Ries $(\sim 24 \mathrm{~km})$ and Chicxulub $(\sim 180 \mathrm{~km})$ impact craters. Geochemistry 65:1-46.

Kring, D.A. (2007) The Chicxulub impact event and its environmental consequences at the Cretaceous-Tertiary boundary. Palaeogeogr Palaeoclimatol Palaeoecol 255:4-21.

Kring, D.A. (2017a) Field Guide: Petrified Forest with Notes about the Impact-Mass Extinction Hypothesis. Lunar and Planetary Institute, Houston, TX, 11 p. LPI Contribution No. 2164.

Kring, D.A. (2017b) Guidebook to the Geology of Barringer Meteorite Crater, Arizona (a.k.a. Meteor Crater), 2nd edition, Lunar and Planetary Institute, Houston TX. 270 p. LPI Contribution No. 2040.

Kring, D.A. (September 8-12, 2019) Updated status of the impact-origin of life hypothesis [abstract 1037]. In The First Billion Years-Habitability Meeting, Big Sky, MT. https:// www.hou.usra.edu/meetings/habitability2019/pdf/1037.pdf 
Kring, D.A. and Boynton, W.V. (1991) Altered spherules of impact melt and associated relic glass from the K/T boundary sediments in Haiti. Geochim Cosmochim Acta 55:1737-1742.

Kring, D.A. and Cohen, B.A. (2002) Cataclysmic bombardment throughout the inner solar system 3.9-4.0 Ga. J Geophys Res Planets 107:5009.

Kring, D.A. and Durda, D.D. (2002) Trajectories and distribution of material ejected from the Chicxulub impact crater: implications for postimpact wildfires. J Geophys Res Planets 107:5062.

Kring, D.A., Melosh, H.J., and Hunten, D.M. (1996) Impactinduced perturbations of atmospheric sulfur. Earth Planet Sci Lett 140:201-212.

Kring, D.A., Wolbach, W.S., Patzer, A., and Goodwin, D. (August 13-17, 2007) A test of the impact-mass extinction hypothesis at the Triassic-Jurassic boundary [abstact 5130]. In 70th Annual Meteoritical Society Meeting, Tucson, AZ, Supplement to Meteoritics \& Planetary Science, Vol. 42, p. 5130.

Kring, D.A., Kramer, G.Y., Collins, G.S., Potter, R.W., and Chandnani, M. (2016) Peak-ring structure and kinematics from a multi-disciplinary study of the Schrödinger impact basin. Nat Commun 7:13161.

Kring, D.A., Claeys, P.H., Gulick, S.P., Morgan, J.V., and Collins, G.S. (2017a) Chicxulub and the exploration of large peak-ring impact craters through scientific drilling. GSA Today 27:5.

Kring, D.A., Schmieder, M., Shaulis, B.J., Riller, U., Cockell, C., and Coolen, M.J.L.; IODP-ICDP Expedition 364 Science Party (2017b) Probing the impact-generated hydrothermal system in the peak ring of the Chicxulub Crater and its potential as a habitat [abstract no. 1212]. In Lunar and Planetary Science XLVIII. LPI Contribution No. 1964. Lunar and Planetary Institute, Houston TX.

Krinov, E.L. (1960) The Tunguska Meteorite. Int Geol Rev 2:8-19.

Krinov, E.L. (1971) New studies of the Sikhote-Alin iron meteorite shower. Meteoritics 6:127-138.

Krogh, T.E., Davis, D.W., and Corfu, F. (1984) Precise U-Pb zircon and baddeleyite ages for the Sudbury area. In The Geology and Ore Deposits of the Sudbury Structure, Vol. 1, edited by by E.G. Naldrett, A.J. Giblin, and P. Pye, Ontario Geological Survey, Toronto, pp 431-446.

Krogh, T.E., Kamo, S.L., Sharpton, V.L., Marin, L.E., and Hildebrands, A.R. (1993) U-Pb ages of single shocked zircons linking distal K/T ejecta to the Chicxulub crater. Nature 366:731-734.

Kröner, A., Byerly, G.R., and Lowe, D.R. (1991) Chronology of early Archaean granite-greenstone evolution in the Barberton Mountain Land, South Africa, based on precise dating by single zircon evaporation. Earth Planet Sci Lett 103:41-54.

Kuiper, Y.D. (2002) The interpretation of inverse isochron diagrams in ${ }^{40} \mathrm{Ar} /{ }^{39} \mathrm{Ar}$ geochronology. Earth Planet Sci Lett 203:499-506.

Kulik, L.A. (1940) The Meteorite Expedition to the stony Tuguska in 1939. DAN Proc USSR Acad Sci 28:597-601.

Kyte, F.T., Zhou, Z., and Wasson, J.T. (1980) Siderophileenriched sediments from the Cretaceous-Tertiary boundary. Nature 288:651-656.

Kyte, F.T., Shukolyukov, A., Hildebrand, A.R., Lugmair, G.W., and Hanova, J. (2011) Chromium-isotopes in Late Eocene impact spherules indicate a likely asteroid belt provenance. Earth Planet Sci Lett 302:279-286.

Kyte, F.T., Shukolyukov, A., Lugmair, G.W., Lowe, D.R., and Byerly, G.R. (2003) Early Archean spherule beds: chromium isotopes confirm origin through multiple impacts of projectiles of carbonaceous chondrite type. Geology 31:283-286.

Lakomy, R. (1990) Distribution of impact induced phenomena in complex terestrial impact structures: implications for transient cavity dimensions. In Lunar and Planetary Science $X X I$, Vol. 21, Lunar and Planetary Institute, Houston, TX, pp 676-677.

Lambert, P., McHone, J.F., Jr., Dietz, R.S., and Houfani, M. (1980) Impact and impact-like structures in Algeria part I: four bowl-shaped depressions. Meteoritics 15:157-179.

Lambert, P., McHone, J.F., Jr., Dietz, R.S., Briedj, M., and Djender, M. (1981) Impact and impact-like structures in Algeria part II: multi-ringed strutures. Meteoritics 16:203-227.

Layer, P.W. (2000) Argon-40/argon-39 age of the El'gygytgyn impact event, Chukotka, Russia. Meteorit Planet Sci 35: 591-599.

Le Feuvre, M. and Wieczorek, M.A. (2011) Nonuniform cratering of the Moon and a revised crater chronology of the inner Solar System. Icarus 214:1-20.

Lehtinen, M., Pesonen, L.J., Stehlik, H., and Kuulusa, M. (2002) The Suvasvesi South structure, Central Finland: new evidences for impact [abstract 1188]. Lunar and Planetary Science, Vol. 33, Lunar and Planetary Institute, Houston, TX. Lepaulard, C., Gattacceca, J., Swanson-Hysell, N., Quesnel, Y., Demory, F., and Osinski, G.R. (2019) A Paleozoic age for the Tunnunik impact structure. Meteorit Planet Sci 54:740-751.

Lindgren, P., Ivarsson, M., Neubeck, A., Broman, C., Henkel, H., and Holm, N.G. (2010) Putative fossil life in a hydrothermal system of the Dellen impact structure, Sweden. Int J Astrobiol 9:137-146.

Lindström, M., Ormö, J., Sturkell, E., and von Dalwigk, I. (2005) The Lockne crater: revision and reassessment of structure and impact stratigraphy. In Impact Tectonics, edited by C. Koeberl and H. Henkel, Springer, Berlin, Heidelberg, pp 357-388.

Lindström, S., Pedersen, G.K., Van De Schootbrugge, B., Hansen, K.H., Kuhlmann, N., Thein, J., Johansson, L., Ingermann Petersen, H., Alwmark, C., Dybkjær, K., Weibel, R., Erlström, M., Nielsen, L.H., Oschmann, W., and Tegner, C. (2015) Intense and widespread seismicity during the endTriassic mass extinction due to emplacement of a large igneous province. Geology 43:387-390.

Liu, K.X., Chen, M., Ding, X.F., Fu, D.P., Ding, P., Shen, C.D., and Xiao, W.S. (2013) AMS radiocarbon dating of lacustrine sediment from an impact crater in northeastern China. Nucl Instrum Methods Phys Res 294:593-596.

Lo, C.-H., Howard, K.T., Chung, S.L., and Meffre, S. (2002) Laser fusion argon-40/argon-39 ages of Darwin impact glass. Meteorit Planet Sci 37:1555-1562.

Losiak, A., Wild, E.M., Geppert, W.D., Huber, M.S., Jõeleht, A., Kriiska, A., Kulkov, A., Paavel, K., Pirkovic, I., Plado, J., and Steier, P. (2016) Dating a small impact crater: an age of Kaali crater (Estonia) based on charcoal emplaced within proximal ejecta. Meteorit Planet Sci 51:681-695.

Losiak, A., Jõeleht, A., Plado, J., Szyszka, M., Wild, E.M., Bronikowska, M., Belcher, C., Kirsimäe, K., and Steier, P. (2017) Dating Ilumetsa Craters (Estonia) based on charcoal emplaced within their proximal ejecta blankets [abstract 1879]. In Lunar and Planetary Science XLVIII. LPI Contribution No. 1964. Lunar and Planetary Institute, Houston, TX.

Losiak, A., Belcher, C., Jõeleht, A., Plado, J., and Szyszko, M. (2019) Death from space: origin of charcoal found in proximal ejecta blanket of Kaali Craters (is NOT what we think) [abstract 2406]. In Lunar and Planetary Science L. LPI 
Contribution No. 2132. Lunar and Planetary Institute, Houston, TX.

Lowe, D.R. and Byerly, G.R. (2010) Did LHB end not with a bang but a whimper? The geologic evidence [abstract 2563]. In Lunar and Planetary Science XLI. LPI Contribution No. 1533. Lunar and Planetary Institute, Houston, TX.

Lowe, D.R., Byerly, G.R., Kyte, F.T., Shukolyukov, A., Asaro, F., and Krull, A. (2003) Spherule beds 3.47-3.24 billion years old in the Barberton Greenstone Belt, South Africa: a record of large meteorite impacts and their influence on early crustal and biological evolution. Astrobiology 3:7-48.

Lowe, D.R., Byerly, G.R., and Kyte, F.T. (2014) Recently discovered 3.42-43.23 Ga impact layers, Barberton Belt, South Africa: $3.8 \mathrm{Ga}$ detrital zircons, Archean impact history, and tectonic implications. Geology 42:747-750.

Lowery, C.M., Bralower, T.J., Owens, J.D., Rodríguez-Tovar, F.J., Jones, H., Smit, J., Whalen, M.T., Claeys, P.H., Farley, K., Gulick, S.P., and Morgan, J.V. (2018) Rapid recovery of life at ground zero of the end-Cretaceous mass extinction. Nature 558:288-291.

Lozej, G.P. and Beales, F.W. (1975) The unmetamorphosed sedimentary fill of the Brent meteorite crater, southeastern Ontario. Can J Earth Sci 12:606-628.

Ludwig, K.R. (August 26, 2008) Isoplot 4.15. Berkeley Geochronology Center Special Publication No. 4, rev. Available online at www.bgc.org/isoplot_etc/isoplot.html (accessed November 18, 2019).

Macdonald, F.A., Wingate, M.T.D., and Mitchell, K. (2005) Geology and age of the Glikson impact structure, Western Australia. Aust J Earth Sci 52:641-651.

Macke, R.J. (2010) Survey of meteorite physical properties density, porosity and magnetic susceptibility. PhD thesis, University of Central Florida, Orlando, FL, 333 p.

Macke, R.J., Britt, D.T., and Consolmagno, G.J. (2011) Density, porosity, and magnetic susceptibility of achondritic meteorites. Meteorit Planet Sci 46:311-326.

MacLagan, E. (2018) Constraints on emplacement and timing of the Steen River impact structure, Alberta, Canada. MSc thesis, University of Alberta, Edmonton, Alberta, Canada, $78 \mathrm{p}$.

MacLagan, E.A., Walton, E.L., Herd, C.D.K., and Dence, M. (2018) Investigation of impact melt in allochthonous craterfill deposits of the Steen River impact structure, Alberta, Canada. Meteorit Planet Sci 53:2285-2305.

MacLeod, N. (1998) Impacts and marine invertebrate extinctions. Geol Soc London Spec Pub 140:217-246.

Magna, T., Žák, K., Pack, A., Moynier, F., Mougel, B., Peters, S., Skála, R., Jonášová, Š., Mizera, J., and Řanda, Z. (2017) Zhamanshin astrobleme provides evidence for carbonaceous chondrite and post-impact exchange between ejecta and Earth's atmosphere. Nat Commun 8:227.

Maier, W.D., Andreoli, M.A., McDonald, I., Higgins, M.D., Boyce, A.J., Shukolyukov, A., Lugmair, G.W., Ashwal, L.D., Gräser, P., Ripley, E.M., and Hart, R.J. (2006) Discovery of a $25-\mathrm{cm}$ asteroid clast in the giant Morokweng impact crater, South Africa. Nature 441:203-206.

Malusà, M.G. and Fitzgerald, P.G., editors (2019) FissionTrack Thermochronology and its Application to Geology. Springer, Cham, Switzerland, 395 p.

Mänttäri, I. and Koivisto, M. (2001) Ion microprobe uraniumlead dating of zircons from the Lappajärvi impact crater, western Finland. Meteorit Planet Sci 36:1087-1095.

Mänttäri, I., Kohonen, J., Kujala, H., and Pihlaja, P. (August 20-28, 2004) A revised age for the Sääksjärvi meteorite impact, southwestern Finland: the connection with a Caledonian foreland basin [abstract 1434]. In 32nd International Geological Congress, Florence, Italy.

Marjanac, T., Marjanac, L., and Tomša, A.M. (2006) Glass spherules in Upper Eocene flysch of Croatian Adriaticevidence of an impact into carbonate target? In Proceedings of the 40th ESLAB-1st International Conference on Impact Cratering in the Solar System, ESA-ESTEC, Noordwijk, Netherlands, pp 231-236.

Mark, D.F., Lindgren, P., and Fallick, A.E. (2014) A highprecision ${ }^{40} \mathrm{Ar} /{ }^{39} \mathrm{Ar}$ age for hydrated impact glass from the Dellen impact, Sweden. In Advances in ${ }^{40} A r{ }^{\beta 9} A r$ Dating: From Archaeology to Planetary Sciences, edited by F. Jourdan, D.F. Mark, and C. Verati, Geological Society of London Special Publications, Vol. 378, Geological Society, London, UK, pp 349-366.

Marrero, S., Phillips, F.M., Caffee, M.W., Smith, S.S., and Kring, D.A. (July 26-30, 2010) Re-dating the Barringer Meteorite Crater (AZ) impact using the cosmogenic chlorine36 surface exposure method [abstract 5150]. In $73^{\text {rd }}$ Annual Meeting of the Meteoritical Society, 2010, New York, NY, Supplement to Meteoritics \& Planetary Science.

Martin, W., Baross, J., Kelley, D., and Russell, M.J. (2008) Hydrothermal vents and the origin of life. Nat Rev Microbiol 6:805-814.

Marvin, U.B. and Kring, D.A. (1992) Authentication controversies and impactite petrography of the New Quebec crater. Meteoritics 27:585-595.

Marzoli, A., Renne, P.R., Piccirillo, E.M., Ernesto, M., Bellieni, G., and De Min, A. (1999) Extensive 200-million-year-old continental flood basalts of the Central Atlantic Magmatic Province. Science 284:616-618.

Masaitis, V.L. (1999) Impact structures of northeastern Eurasia: the territories of Russia and adjacent countries. Meteorit Planet Sci 34:691-711.

Masaitis, V.L. (2002) The middle Devonian Kaluga impact crater (Russia): new interpretation of marine setting. Deep Sea Res Part II Top Stud Oceanogr 49:1157-1169.

Masaitis, V.L., Danilin, A.N., Mashchak, M.S., Raikhlin, A.I., Selivanovskaia, T.V., and Shadenkov, E.M. (1980) The Geology of Astroblemes. Nedra Press, Leningrad, 231 p.

Masaitis, V.L. and Raikhlin, A.I. (1986) The Popigai crater was formed by the impact of an ordinary chondrite. Akad Nauk SSSR Doklady 286:1476-1478.

Master, S., Dumont, P., and Ladmirant, H. (2001) Age constraints on the Luizi Structure, a possible new impact structure on the Kundelungu Plateau, Katanga Province, Democratic Republic of Congo. Meteorit Planet Sci Suppl 36:A124.

Maziviero, M.V., Vasconcelos, M.A., Crósta, A.P., Góes, A.M., Reimold, W.U., and De Carneiro, C. (2013) Geology and impact features of Riachão structure, northern Brazil. Meteorit Planet Sci 48:2044-2058.

Mazrouei, S., Ghent, R.R., Bottke, W.F., Parker, A.H., and Gernon, T.M. (2019) Earth and Moon impact flux increased at the end of the Paleozoic. Science 363:253-257.

McDonald, I. (2002) Clearwater East impact structure: a reinterpretation of the projectile type using new platinum-group element data from meteorites. Meteorit Planet Sci 37: 459-464.

McDonald, I., Bartosova, K., and Koeberl, C. (2009) Search for a meteoritic component in impact breccia from the Eyreville core, Chesapeake Bay impact structure: considerations from platinum-group element contents. In The ICDP-USGS Deep Drilling Project in the Chesapeake Bay Impact Structure: 
Results from the Eyreville Core Holes, edited by G.S. Gohn, C. Koeberl, K.G. Miller, and W.U. Reimold, GSA, Boulder, CO, pp 469-479.

McDougall, I. and Harrison, T.M. (1999) Geochronology and Thermochronology by the ${ }^{40} \mathrm{Ar}{ }^{39} \mathrm{Ar}$ Method, 2nd edition, Oxford University Press, New York, NY, 288 p.

McEwen, A.S., Moore, J.M., and Shoemaker, E.M. (1997) The Phanerozoic impact cratering rate: evidence from the farside of the Moon. J Geophys Res Planets 102:9231-9242.

McGetchin, T.R., Settle, M., and Head, J.W. (1973) Radial thickness variation in impact crater ejecta: implications for lunar basin deposits. Earth Planet Sci Lett 20:226-236.

McGregor, M., McFarlane, C.R.M., and Spray, J.G. (2018) In situ LA-ICP-MS apatite and zircon U-Pb geochronology of the Nicholson Lake impact structure, Canada: shock and related thermal effects. Earth Planet Sci Lett 504: 185-197.

McGregor, M., McFarlane, C.R.M., and Spray, J.G. (2019) In situ multiphase $\mathrm{U}-\mathrm{Pb}$ geochronology and shock analysis of apatite, titanite and zircon from the Lac La Moinerie impact structure, Canada. Contrib Mineral Petrol 174:62.

McHone, J.F. and Sorkhabi, R.B. (1994) Apatite fission-track age of Marquez Dome impact structure, Texas. In Lunar and Planetary Science $X X V$, Lunar and Planetary Institute, Houston, TX, pp 881-882.

Meier, M.M. and Holm-Alwmark, S. (2017) A tale of clusters: no resolvable periodicity in the terrestrial impact cratering record. Month Not Royal Astronom Soc 467:2545-2551.

Meisel, T., Koeberl, C., and Ford, R.J. (1990) Geochemistry of Darwin impact glass and target rocks. Geochim Cosmochim Acta 54:1463-1474.

Meldrum, A., Boatner, L.A., Weber, W.J., and Ewing, R.C. (1998) Radiation damage in zircon and monazite. Geochim Cosmochim Acta 62:2509-2520.

Melosh, H.J. (1989) Impact Cratering: A Geologic Process. Oxford University Press, New York, 253 p.

Melosh, H.J. and Ivanov, B.A. (1999) Impact crater collapse. Ann Rev Earth Planet Sci 27:385-415.

Melosh, H.J. and Stansberry, J.A. (1991) Doublet craters and the tidal disruption of binary asteroids. Icarus 94:171-179.

Melosh, H.J., Schneider, N.M., Zahnle, K.J., and Latham, D. (1990) Ignition of global wildfires at the Cretaceous/Tertiary boundary. Nature 343:251-254.

Mercer, C.M. and Hodges, K.V. (2016) ArAR - a software tool to promote the robust comparison of $\mathrm{K}-\mathrm{Ar}$ and ${ }^{40} \mathrm{Ar} /{ }^{39} \mathrm{Ar}$ dates published using different decay, isotopic, and monitorage parameters. Chem Geol 440:148-163.

Merrihue, C. and Turner, G. (1966) Potassium-argon dating by activation with fast neutrons. J Geophys Res 71:28522857.

Merrill, G.K. (1980) Ordovician conodonts from the Aaland islands, Finland. GFF 101:329-341.

Michel, P. and Morbidelli, A. (2007) Review of the population of impactors and the impact cratering rate in the inner solar system. Meteorit Planet Sci 42:1861-1869.

Miljković, K., Collins, G.S., Mannick, S., and Bland, P.A. (2013) Morphology and population of binary asteroid impact craters. Earth Planet Sci Lett 363:121-132.

Miljković, K., Collins, G.S., and Bland, P.A. (2014) Reply to comment on:"supportive comment on: "morphology and population of binary asteroid impact craters," by K. Miljković, GS Collins, S. Mannick and PA Bland-an updated assessment." Earth Planet Sci Lett 405:285-286.
Miller, R.M. (2010) Roter Kamm impact crater of Namibia: new data on rim structure, target rock geochemistry, ejecta, and meteorite trajectory. In Large Meteorite Impacts and Planetary Evolution IV, GSA Special Paper 465, edited by R.L. Gibson and W.U. Reimold, Geological Society of America, Boulder, CO, pp 489-508.

Milstein, R.L. (1994) The Calvin impact crater, Cass County, Michigan: identification and analysis of a subsurface Ordovician astrobleme. PhD thesis, Oregon State University, Corvallis, Oregon, 126 p.

Milton, D.J. and Macdonald, F.A. (2005) Goat Paddock, Western Australia: an impact crater near the simple-complex transition. Aust J Earth Sci 52:689-697.

Minton, D.A. and Malhotra, R. (2010) Dynamical erosion of the asteroid belt and implications for large impacts in the inner Solar System. Icarus 207:744-757.

Montalvo, P.E., Cavosie, A.J., Kirkland, C.L., Evans, N.J., McDonald, B.J., Talavera, C., Erickson, T.M., and LugoCenteno, C. (2018) Detrital shocked zircon provides first radiometric age constraint $(<1472 \mathrm{Ma})$ for the Santa Fe impact structure, New Mexico, USA. GSA Bull 131:845-863.

Montanari, A., Bagatin, A.C., and Farinella, P. (1998) Earth cratering record and impact energy flux in the last $150 \mathrm{Ma}$. Planet Space Sci 46:271-281.

Morbidelli, A. (1999) Origin and evolution of near Earth asteroids. Celest Mech Dyn Astronom 73:39-50.

Morgan, J.W., Janssens, M.J., Hertogen, J., Gros, J., and Takahashi, H. (1979) Ries impact crater, southern Germany: search for meteoritic material. Geochim Cosmochim Acta 43: 803-815.

Morgan, J., Gulick, S., Bralower, T., Chenot, E., Christen, G., Claeys, P.H., Cockell, C., Collins, G., Coolen, M., Ferrière, L., Gebhardt, C., Goto, K., Jones, H., Kring, D., Le Ber, E., Lofi, J., Long, X., Lowery, C., Mellet, C., Ocampo-Torres, R., Osinski, G., Perez-Cruz, L., Pickersgill, A., Poelchau, M., Rae, A., Rasmussen, C., Rebolledo-Vieyra, M., Riller, U., Sato, H., Schmitt, D., Smit, J., Tikoo-Schantz, S., Tomioka, N., Fucugauchi, J.U., Whalen, M., Wittmann, A., Yamaguchi, K., and Zylberman, W. (2016) The formation of peak rings in large impact craters. Science 354:878-882.

Morrow, J.R., Sandberg, C.A., Malkowski, K., and Joachimski, M.M. (2009) Carbon isotope chemostratigraphy and precise dating of middle Frasnian (lower Upper Devonian) Alamo Breccia, Nevada, USA. Palaeogeogr Palaeoclimatol Palaeoecol 282:105-118.

Mougel, B., Moynier, F., Göpel, C., and Koeberl, C. (2017) Chromium isotope evidence in ejecta deposits for the nature of Paleoproterozoic impactors. Earth Planet Sci Lett 460: 105-111.

Mougel, B., Moynier, F., Koeberl, C., Wielandt, D., and Bizzarro, M. (2019) Identification of a meteoritic component using chromium isotopic composition of impact rocks from the Lonar impact structure, India. Meteorit Planet Sci 54:2592-2599.

Movshovic, Y.V., Milyavsk, A.Y., and Titova, G.N. (1991) Geology of the northeastern margin of Donets ridge and dating of the Kamensk and Gusev impact craters. Int Geol Rev 33:623-635.

Muller, R.A. (1985) Evidence for Nemesis: A Solar Companion Star (No. LBL-20438; CONF-850183-1). Lawrence Berkeley Lab., Berkeley, CA, 20 p.

Muscheler, R., Adolphi, F., and Svensson, A. (2014) Challenges in ${ }^{14} \mathrm{C}$ dating towards the limit of the method inferred from anchoring a floating tree ring radiocarbon chronology to ice 
core records around the Laschamp geomagnetic field minimum. Earth Planet Sci Lett 394:209-215.

Nasdala, L., Wenzel, M., Vavra, G., Irmer, G., Wenzel, T., and Kober, B. (2001) Metamictisation of natural zircon: accumulation versus thermal annealing of radioactivity-induced damage. Contrib Mineral Petrol 141:125-144.

Naumov, M.V. (2005) Principal features of impact-generated hydrothermal circulation systems: mineralogical and geochemical evidence. Geofluids 5:165-184.

Nebel, O., Scherer, E.E., and Mezger, K. (2011) Evaluation of the ${ }^{87} \mathrm{Rb}$ decay constant by age comparison against the $\mathrm{U}-\mathrm{Pb}$ system. Earth Planet Sci Lett 301:1-8.

Nédélec, A., Paquette, J.L., Yokoyama, E., Trindade, R.I., Aigouy, T., and Baratoux, D. (2013) In situ U/Pb dating of impact-produced zircons from the Vargeão Dome (Southern Brazil). Meteorit Planet Sci 48:420-431.

Nesvorný, D., Bottke, W.F., Jr., Dones, L., and Levison, H.F. (2002) The recent breakup of an asteroid in the main-belt region. Nature 417:720-721.

Nesvorný, D., Vokrouhlický, D., and Bottke, W.F. (2006) The breakup of a main-belt asteroid 450 thousand years ago. Science 312:1490.

Neukum, G. and Ivanov, B.A. (1994) Crater size distributions and impact probabilities on Earth from lunar, terrestrialplanet, and asteroid cratering data. In Hazards due to Comets and Asteroids, Space Science Series, edited by T. Gehrels, M.S. Matthews, and A. Schumann, University of Arizona Press, Tucson, AZ, pp 359-416.

Neukum, G., Ivanov, B.A., and Hartmann, W.K. (2001) Cratering records in the inner solar system in relation to the lunar reference system. In Chronology and evolution of Mars, edited by R. Kallenbach, J. Geiss, and W.K. Hartmann, Kluwer, Dordrecht, The Netherlands, pp 55-86.

Neville, A.S., Cook, D.J., Afifi, A.M., and Stewart, S.A. (2014) Five buried crater structures imaged on reflection seismic data in Saudi Arabia. GeoArabia 19:17-44.

Newsom, H.E. (1980) Hydrothermal alteration of impact melt sheets with implications for Mars. Icarus 44:207-216.

Newsom, H.E., Graup, G., Sewards, T., and Keil, K. (1986) Fluidization and hydrothermal alteration of the suevite deposit at the Ries crater, West Germany, and implications for Mars. J Geophys Res Solid Earth 91:E239-E251.

Newsom, H.E., Hagerty, J.J., and Thorsos, I.E. (2001) Location and sampling of aqueous and hydrothermal deposits in Martian impact craters. Astrobiology 1:71-88.

Nier, A.O. (1939) The isotopic composition of radiogenic leads and the measurements of geological time. II. Phys Rev 55: 153-163.

Nisbet, E.G. and Sleep, N.H. (2001) The habitat and nature of early life. Nature 409:1083-1091.

Offield, T.W. and Pohn, H.A. (1977) Deformation at the Decaturville impact structure, Missouri. In Impact and Explosion Cratering-Planetary and Terrestrial Implications, edited by D.J. Roddy, R.O. Pepin, and R.B. Merrill, Pergamon Press, New York, NY, pp 321-341.

Öhman, T. (2007) The origin and tectonic modification of the Saarijärvi impact structure, northern Finland [abstact 8019]. In Proceedings of the Bridging the Gap II-Effect of Target Properties on the Impact Cratering Process, Saint-Hubert, Quebec. pp 85-86. LPI, Houston, TX, Contribution No. 1360.

Olierook, H.K.H., Jourdan, F., and Merle, R.E. (2019) Age of the Barremian-Aptian boundary and onset of the Cretaceous Normal Superchron. Earth Sci Rev 197:102906.
Oliveira, G.J.G.D., Chamani, M.A.C., Góes, A.M., Crósta, A.P., Vasconcelos, M.A.R., and Reimold, W.U. (2017) Geological investigation of the central portion of the Santa Marta impact structure, Piauí State, Brazil. Brazil. J Geol 47:673-692.

Olsen, P.E., Kent, D.V., Sues, H.D., Koeberl, C., Huber, H., Montanari, A., Rainforth, E.C., Fowell, S.J., Szajna, M.J., and Hartline, B.W. (2002) Ascent of dinosaurs linked to an iridium anomaly at the Triassic-Jurassic boundary. Science 296: 1305-1307.

Onoue, T., Sato, H., Yamashita, D., Ikehara, M., Yasukawa, K. Fujinaga, K., Kato, Y., and Matsuoka, A. (2016) Bolide impact triggered Late Triassic extinction event in equatorial Panthalassa. Sci Rep 6, 29609.

Ormö, J. (1994) The pre-impact Ordovician stratigraphy of the Tvären Bay impact structure, SE Sweden. GFF 116:139-144.

Ormö, J., Sturkell, E., Alwmark, C., and Melosh, J. (2014) First known terrestrial impact of a binary asteroid from a main belt breakup event. Sci Rep 4:6724.

Ormö, J., Nielsen, A.T., and Alwmark, C. (2017) The Vakkejokk Breccia: an Early Cambrian proximal impact ejecta layer in the North-Swedish Caledonides. Meteorit Planet Sci 52:623-645.

Osinski, G.R. (September 2003) Shocked into life. New Scientist, v., pp 40-43.

Osinski, G.R. (October 2011) The role of meteorite impacts in the origin and evolution of life [Paper No. 24-2]. In Geological Society of America Annual Meeting, Minneapolis, MN.

Osinski, G.R. and Grieve, R.A.F. (2019) Impact Earth: a new resource for outreach, teaching, and research. Elements 15 : 70-71.

Osinski, G.R. and Pierazzo, E., editors (2012) Impact Cratering: Processes and Products. John Wiley \& Sons, Hoboken, NJ, $330 \mathrm{p}$.

Osinski, G.R., Spray, J.G., and Lee, P. (2001) Impact-induced hydrothermal activity within the Haughton impact structure, arctic Canada: generation of a transient, warm, wet oasis. Meteorit Planet Sci 36:731-745.

Osinski, G.R., Kieniewicz, J., Smith, J.R., Boslough, M.B., Eccleston, M., Schwarcz, H.P., Kleindienst, M.R., Haldemann, A.F., and Churcher, C.S. (2008) The Dakhleh Glass: product of an impact airburst or cratering event in the Western Desert of Egypt? Meteorit Planet Sci 43:20892107.

Osinski, G.R., Tornabene, L.L., and Grieve, R.A.F. (2011) Impact ejecta emplacement on terrestrial planets. Earth Planet Sci Lett 310:167-181.

Osinski, G.R., Grieve, R.A.F., and Tornabene, L.L. (2012) Excavation and impact ejecta emplacement. In Impact Cratering: Processes and Products, edited by G.R. Osinski and E. Pierazzo, Wiley-Blackwell, Chichester, pp 47-59.

Osinski, G.R., Tornabene, L.L., Banerjee, N.R., Cockell, C.S., Flemming, R., Izawa, M.R., McCutcheon, J., Parnell, J., Preston, L.J., Pickersgill, A.E., and Pontefract, A. (2013) Impact-generated hydrothermal systems on Earth and Mars. Icarus 224:347-363.

Osinski, G.R., Caudill, C.M., Cockell, C.S., Pontefract, A., Sapers, H.M., Simpson, S., Svensson, M., and Tornabene, L.L. (2017) The role of meteorite impacts in creating a habitable early Mars [abstract 3071]. In Fourth Conference on Early Mars: Geologic, Hydrologic, and Climatic Evolution and the Implications for Life, LPI, Houston, TX.

Osinski, G.R., Grieve, R.A., Bleacher, J.E., Neish, C.D., Pilles, E.A., and Tornabene, L.L. (2018) Igneous rocks formed by hypervelocity impact. J Volcanol Geotherm Res 353:25-54. 
Pálfy, J. (2004) Did the Puchezh-Katunki impact trigger an extinction?. In Cratering in Marine Environments and on Ice, edited by H. Dypvik, M.J. Burchell, and P.H. Claeys, Springer, Berlin, Heidelberg, pp 135-148.

Palme, H., Janssens, M.J., Takahashi, H., Anders, E., and Hertogen, J. (1978) Meteoritic material at five large impact craters. Geochim Cosmochim Acta 42:313-323.

Palme, H., Göbel, E., and Grieve, R.A.F. (1979) The distribution of volatile and siderophile elements in the impact melt of East Clearwater/Quebec. Proc Lunar Planet Sci Conf 10: 2465-2492.

Palme, H., Grieve, R.A.F., and Wolf, R. (1981) Identification of the projectile at the Brent crater, and further considerations of projectile types at terrestrial craters. Geochim Cosmochim Acta 45:2417-2424.

Parnell, J., Boyce, A., Thackrey, S., Muirhead, D., Lindgren, P., Mason, C., Taylor, C., Still, J., Bowden, S., Osinski, G.R., and Lee, P. (2010) Sulfur isotope signatures for rapid colonization of an impact crater by thermophilic microbes. Geology 38:271-274.

Parnell, J., Mark, D., Fallick, A.E., Boyce, A., and Thackrey, S. (2011) The age of the Mesoproterozoic Stoer Group sedimentary and impact deposits, NW Scotland. J Geol Soc 168: 349-358.

Pasek, M. and Lauretta, D. (2008) Extraterrestrial flux of potentially prebiotic $\mathrm{C}, \mathrm{N}$, and $\mathrm{P}$ to the early Earth. Orig Life Evol Biosph 38:5-21.

Pati, J.K., Reimold, W.U., Koeberl, C., and Pati, P. (2008) The Dhala structure, Bundelkhand craton, Central India-eroded remnant of a large Paleoproterozoic impact structure. $\mathrm{Me}$ teorit Planet Sci 43:1383-1398.

Pati, J.K., Jourdan, F., Armstrong, R.A., Reimold, W.U., and Prakash, K. (2010) First SHRIMP U-Pb and ${ }^{40} \mathrm{Ar} /{ }^{39} \mathrm{Ar}$ chronological results from impact melt breccia from the Paleoproterozoic Dhala impact structure, India. In Large Meteorite Impacts and Planetary Evolution IV, Special Paper 465, edited by R.L. Gibson and W.U. Reimold, Geological Society of America, Boulder, CO, pp 571-591.

Pati, J.K., Qu, W.J., Koeberl, C., Reimold, W.U., Chakarvorty, M., and Schmitt, R.T. (2017) Geochemical evidence of an extraterrestrial component in impact melt breccia from the Paleoproterozoic Dhala impact structure, India. Meteoritics Planet Sci 52:722-736.

Patzer, A., Kring, D.A., Goodwin, D.H., Ward, P.D., and Haggert, J.W. (2004) A lithological investigation of marine strata from the Triassic-Jurassic interval, Queen Charlotte Islands, British Columbia, including a search for shocked quartz [abstract 1578]. In Lunar and Planetary Science $X X X V$. LPI, Houston TX.

Pedersen, H., de Bon, C.C., and Lindgren, H. (1992) Vaca Muerta mesosiderite strewnfield. Meteoritics 27:126-135.

Percival, L.M.E., Davies, J.H.F.L., Schaltegger, U., De Vleeschouwer, D., Da Silva, A.C., and Föllmi, K.B. (2018) Precisely dating the Frasnian-Famennian boundary: implications for the cause of the Late Devonian mass extinction. Sci Rep 8:9578.

Pesonen, L.J., Järvelä, J., Sarapää, O., and Pietarinen, H. (1996a) The Iso-Naakkima meteorite impact structure: physical properties and paleomagnetism of a drill core. $M e$ teorit Planet Sci Suppl 31:A105-A106.

Pesonen, L.J., Lehtinen, M., Deutsch, A., Elo, S., and Lukkarinen, H. (1996b) New geophysical and petrographic results of the Suvasvesi N impact structure, Finland. Lunar Planet Sci 27:1021-1022.
Pesonen, L.J., Elo, S., Lehtinen, M., Jokinen, T., Puranen, R., and Kivekäs, L. (1999) Lake Karikkoselkä impact structure, central Finland: new geophysical and petrographic results. In Large Meteorite Impacts and Planetary Evolution II, GSA Special Paper 339, edited by B.O. Dressler and V.L. Sharpton, Geological Society of America, Boulder, CO, pp 131148.

Pesonen, L.J., Mader, D., Gurov, E.P., Koeberl, C., Kinnunen, K.A., Donadini, F., and Handler, R. (2004) Paleomagnetism and ${ }^{40} \mathrm{Ar} /{ }^{39} \mathrm{Ar}$ age determinations of impactites from the Ilyinets structure, Ukraine. In Cratering in Marine Environments and on Ice, edited by H. Dypvik, M.J. Burchell, and P.H. Claeys, Springer, Berlin, Heidelberg, pp 251-280.

Petaev, M.I. (1992) Meteorite Sterlitamak-a new crater forming fall. Meteoritics 27:276.

Peucker-Ehrenbrink, B. (2001) Iridium and osmium as tracers of extraterrestrial matter in marine sediments. In Accretion of Extraterrestrial Matter Throughout Earth's History, edited by B. Peucker-Ehrenbrink and B. Schmitz, Springer, Boston, MA, pp 163-178.

Pickersgill, A.E., Christou, E., Mark, D.F., Lee, M.R., Tremblay, M.M., Rasmussen, C., Morgan, J.V., Gulick, S.P.S., Schmieder, M., Bach, W., Osinski, G.R., Simpson, S.L., Kring, D.A., Cockell, C.C., Collins, G.S., Christeson, G.L., Tikoo, S.M., Stockli, D.F., Ross, C., Wittmann, A., and Swindle, T.D.; the Expedition 364 Scientists. (September 30 to October 1, 2019a) Six million years of hydrothermal activity at Chicxulub? [abstract 5082]. In Large Meteorite Impacts VI 2019, Brasília, Brazil, LPI Contribution No. 2136. Lunar and Planetary Institute, Houston, TX.

Pickersgill, A.E., Mark, D.F., Lee, M.R., and Osinski, G.R. (2019b) A refined age for the Gow Lake impact structure [abstract 2375]. In Lunar and Planetary Science L. LPI Contribution No. 2132. Lunar and Planetary Institute, Houston, TX.

Pidgeon, R.T., O’Neil, J.R., and Silver, L.T. (1966) Uranium and lead isotopic stability in a metamict zircon under experimental hydrothermal conditions. Science 154:1538-1540.

Pierazzo, E., Kring, D.A., and Melosh, H.J. (1998) Hydrocode simulation of the Chicxulub impact event and the production of climatically active gases. J Geophys Res Planets 103: 28607-28625.

Pinto, J.A., Warme, J.E., Evans, K.R., King, D.T., and Morrow, J.R. (2008) Alamo Event, Nevada: crater stratigraphy and impact breccia realms. In The Sedimentary Record of Meteorite Impacts, GSA Special Paper 437, edited by K.R. Evans, Geological Society of America, Boulder, CO, pp 99-137.

Pirajno, F., Hawke, P., Glikson, A.Y., Haines, P.W., and Uysal, T. (2003) Shoemaker impact structure, Western Australia. Aust J Earth Sci 50:775-796.

Plado, J., Hietala, S., Kreitsmann, T., Lerssi, J., Nenonen, J., and Pesonen, L.J. (2018) Summanen, a new meteorite impact structure in Central Finland. Meteorit Planet Sci 53:2413-2426.

Plescia, J.B., Shoemaker, E.M., and Shoemaker, C.S. (1994) Gravity survey of the Mount Toondina impact structure, South Australia. J Geophys Res Planets 99:13167-13179.

Pohl, J., Stöffler, D., Gall, H.V., and Ernstson, K. (1977) The Ries impact crater. In Impact and Explosion CrateringPlanetary and Terrestrial Implications, edited by D.J. Roddy, R.O. Pepin, and R.B. Merrill, Pergamon Press, New York, NY, pp 343-404.

Pope, K.O., Baines, K.H., Ocampo, A.C., and Ivanov, B.A. (1997) Energy, volatile production, and climatic effects of the 
Chicxulub Cretaceous/Tertiary impact. J Geophys Res Planets 102:21645-21664.

Popova, O.P., Jenniskens, P., Emel'yanenko, V., Kartashova, A., Biryukov, E., Khaibrakhmanov, S., Shuvalov, V.V., Rybnov, Y., Dudorov, A., Grokhovsky, V.I., Badyukov, D.D., Yin, Q.-Z., Gural, P.S., Albers, J., Granvik, M., Evers, L.G., Kuiper, J., Kharlamov, V., Solovyov, A., Rusakov, Y.S., Korotkiy, S., Serdyuk, I., Korochantsev, A.V., Larionov, M.Y., Glazachev, D., Mayer, A.E., Gisler, G., Gladkovsky, S.V., Wimpenny, J., Sanborn, M.E., Yamakawa, A., Verosub, K.L., Rowland, D.J., Roeske, S., Botto, N.W., Friedrich, J.M., Zolensky, M.E., Le, L., Ross, D., Ziegler, K., Nakamura, T., Ahn, I., Lee, J.I., Zhou, Q., Li, X.-H., Li, Q.-L., Liu, Y., Tang, G.-Q., Hiroi, T., Sears, D., Weinstein, I.A., Vokhmintsev, A.S., Ishchenko, A.V., Schmitt-Kopplin, P., Hertkorn, N., Nagao, K., Haba, M.K., Komatsu, M., and Mikouchi, T. (2013) Chelyabinsk airburst, damage assessment, meteorite recovery, and characterization. Science 342: 1069-1073.

Prescott, J.R., Robertson, G.B., Shoemaker, C., Shoemaker, E.M., and Wynn, J. (2004) Luminescence dating of the Wabar meteorite craters, Saudi Arabia. J Geophys Res Planets 109:E01008.

Prinn, R.G. and Fegley, B., Jr. (1987) Bolide impacts, acid rain, and biospheric traumas at the Cretaceous-Tertiary boundary. Earth Planet Sci Lett 83:1-15.

Racki, G. (2012) The Alvarez impact theory of mass extinction; limits to its applicability and the "great expectations syndrome." Acta Palaeontol Polonica 57:681-702.

Ramezani, J., Bowring, S.A., Pringle, M.S., Winslow, F.D., III, and Rasbury, E.T. (2005) The Manicouagan impact melt rock: a proposed standard for the intercalibration of $\mathrm{U}-\mathrm{Pb}$ and ${ }^{40} \mathrm{Ar} /{ }^{39} \mathrm{Ar}$ isotopic systems. Geochim Cosmochim Acta 69: A321.

Rampino, M.R. (1999) Impact crises, mass extinctions, and galactic dynamics: the case for a unified theory. In Large Meteorite Impacts and Planetary Evolution II, GSA Special Paper 339, edited by B.O. Dressler and V.L. Sharpton, Geological Society of America, Boulder, CO, pp 241-248.

Rampino, M.R. and Caldeira, K. (2015) Periodic impact cratering and extinction events over the last 260 million years. Month Not Royal Astronom Soc 454:3480-3484.

Rampino, M.R. and Caldeira, K. (2017) Correlation of the largest craters, stratigraphic impact signatures, and extinction events over the past 250 Myr. Geosci Frontiers 8: 1241-1245.

Rampino, M.R. and Haggerty, B.M. (1996) Impact crises and mass extinctions: a working hypothesis. In The CretaceousTertiary Event and Other Catastrophes in Earth History, GSA Special Paper 307, edited by G. Ryder, D.E. Fastovsky, and S. Gartner, Geological Society of America, Boulder, CO, pp 241-248.

Rampino, M.R. and Stothers, R.B. (1984) Terrestrial mass extinctions, cometary impacts and the Sun's motion perpendicular to the galactic plane. Nature 308:709-712.

Rampino, M.R., Haggerty, B.M., and Pagano, T.C. (1997) A unified theory of impact crises and mass extinctions: quantitative tests. Ann N Y Acad Sci 822:403-431.

Rasmussen, B., Blake, T.S., and Fletcher, I.R. (2005) U-Pb zircon age constraints on the Hamersley spherule beds: evidence for a single $2.63 \mathrm{Ga}$ Jeerinah-Carawine impact ejecta layer. Geology 33:725-728.

Rathbun, J.A. and Squyres, S.W. (2002) Hydrothermal systems associated with Martian impact craters. Icarus 157:362-372.
Raukas, A., Tiirmaa, R., Kaup, E., and Kimmel, K. (2001) The age of the Ilumetsa meteorite craters in southeast Estonia. Meteorit Planet Sci 36:1507-1514.

Raup, D.M. (1990) Impact as a general cause of extinction: a feasibility test. In Global Catastrophes in Earth History-An Interdisciplinary Conference on Impacts, Volcanism, and Mass Mortality, GSA Special Paper 247, edited by V.L. Sharpton and P.D. Ward, Geological Society of America, Boulder, CO, pp 27-32.

Raup, D.M. (1992) Large-body impact and extinction in the Phanerozoic. Paleobiology 18:80-88.

Raup, D.M. and Sepkoski, J.J. (1984) Periodicity of extinctions in the geologic past. Proc Natl Acad Sci U S A 81: 801-805.

Ray, J.S., Veizer, J., and Davis, W.J. (2003) C, O, Sr and Pb isotope systematics of carbonate sequences of the Vindhyan Supergroup, India: age, diagenesis, correlations and implications for global events. Precambrian Res 121:103-140.

Read, W.F. (1983) Shatter cones at Glover Bluff, Wisconsin. Meteoritics 18:241-243.

Reidel, S.P. and Koucky, F.L. (1981) The Serpent Mound cryptoexplosion structure, southwestern Ohio. GSA Cincinnati '81 Field Trip Guidebooks: Am Geol Inst 2:391-403.

Reimold, W.U. and Koeberl, C. (2000) Critical comment on: AJ Mory et al. "Woodleigh, Carnarvon Basin, Western Australia: a new $120 \mathrm{~km}$ diameter impact structure." Earth Planet Sci Lett 184:353-357.

Reimold, W.U. and Koeberl, C. (2014) Impact structures in Africa: a review. J Afr Earth Sci 93:57-175.

Reimold, W.U., Grieve, R.A.F., and Palme, H. (1981) Rb-Sr dating of the impact melt from East Clearwater, Quebec. Contrib Mineral Petrol 76:73-76.

Reimold, W.U., Koeberl, C., and Reddering, J.S. (1998) The 1992 drill core from the Kalkkop impact crater, Eastern Cape Province, South Africa: stratigraphy, petrography, geochemistry and age. J Afr Earth Sci 26:573-592.

Reimold, W.U., Kelley, S.P., Sherlock, S.C., Henkel, H., and Koeberl, C. (2005) Laser argon dating of melt breccias from the Siljan impact structure, Sweden: implications for a possible relationship to Late Devonian extinction events. $\mathrm{Me}$ teorit Planet Sci 40:591-607.

Reimold, W.U., Koeberl, C., Gupta, H., and Fareeduddin, F. (2008) Catastrophes, extinctions and evolution: 50 years of impact cratering studies. Geol Soc India 66:69-110.

Reimold, W.U., Hauser, N., and Crósta, A.P. (2018) The Impact Record of Southwest Gondwana. In Geology of Southwest Gondwana, edited by S. Siegesmund, M.A.S. Basei, P. Oyhantçabal, and S. Oriolo, Springer, Cham, Switzerland, pp 677-688.

Reiners, P.W. (2005) Zircon (U-Th)/He thermochronometry. In Low-Temperature Thermochronology: Techniques, Interpretations, and Applications, edited by P.W. Reiners and T.A. Ehlers, Reviews in Mineralogy and Geochemistry, Vol. 58, Mineralogical Society of America, Washington, DC, pp 151-179.

Reiners, P.W., Spell, T.L., Nicolescu, S., and Zanetti, K.A. (2004) Zircon (U-Th)/He thermochronometry: he diffusion and comparisons with ${ }^{40} \mathrm{Ar} /{ }^{39} \mathrm{Ar}$ dating. Geochim Cosmochim Acta 68:1857-1887.

Renne, P.R., Reimold, W.U., Koeberl, C., Hough, R., and Claeys, P.H. (2002) Comment on: "K-Ar evidence from illitic clays of a Late Devonian age for the $120 \mathrm{~km}$ diameter Woodleigh impact structure, Southern Carnarvon Basin, Western Australia,' by IT Uysal, SD Golding, AY Glikson, 
AJ Mory and M. Glikson [Earth Planet. Sci. Lett. 192 (2001) 218-289]. Earth Planet Sci Lett 201:247-252.

Renne, P.R., Melosh, H.J., Farley, K.A., Reimold, W.U., Koeberl, C., Rampino, M.R., Kelly, S.P., and Ivanov, B.A. (2004) Is Bedout an impact crater? Take 2. Science 306: 610-612.

Renne, P.R., Mundil, R., Balco, G., Min, K., and Ludwig, K.R. (2010) Joint determination of ${ }^{40} K$ decay constants and ${ }^{40} \mathrm{Ar} * /{ }^{40} \mathrm{~K}$ for the Fish Canyon sanidine standard, and improved accuracy for ${ }^{40} \mathrm{Ar} /{ }^{39} \mathrm{Ar}$ geochronology. Geochim Cosmochim Acta 74:5349-5367.

Renne, P.R., Balco, G., Ludwig, K.R., Mundil, R., and Min, K. (2011) Response to the comment by WH Schwarz et al. on "Joint determination of ${ }^{40} \mathrm{~K}$ decay constants and ${ }^{40} \mathrm{Ar} * /{ }^{40} \mathrm{~K}$ for the Fish Canyon sanidine standard, and improved accuracy for ${ }^{40} \mathrm{Ar} /{ }^{39} \mathrm{Ar}$ geochronology" by $\mathrm{PR}$ Renne et al. (2010). Geochim Cosmochim Acta 75:5097-5100.

Renne, P.R., Deino, A.L., Hilgen, F.J., Kuiper, K.F., Mark, D.F., Mitchell, W.S., Morgan, L.E., Mundil, R., and Smit, J. (2013) Time scales of critical events around the CretaceousPaleogene boundary. Science 339:684-687.

Renne, P.R., Sprain, C.J., Richards, M.A., Self, S., Vanderkluysen, L., and Pande, K. (2015) State shift in Deccan volcanism at the Cretaceous-Paleogene boundary, possibly induced by impact. Science 350:76-78.

Renne, P.R., Arenillas, I., Arz, J.A., Vajda, V., Gilabert, V., and Bermúdez, H.D. (2018) Multi-proxy record of the Chicxulub impact at the Cretaceous-Paleogene boundary from Gorgonilla Island, Colombia. Geology 46:547-550.

Retallack, G.J. (1996) Acid trauma at the Cretaceous-Tertiary boundary in eastern Montana. GSA Today 6:1-7.

Retallack, G.J., Leahy, G.D., and Spoon, M.D. (1987) Evidence from paleosols for ecosystem changes across the Cretaceous/ Tertiary boundary in eastern Montana. Geology 15:1090 1093.

Retallack, G.J., Seyedolali, A., Krull, E.S., Holser, W.T., Ambers, C.P., and Kyte, F.T. (1998) Search for evidence of impact at the Permian-Triassic boundary in Antarctica and Australia. Geology 26:979-982.

Richards, M.A., Alvarez, W., Self, S., Karlstrom, L., Renne, P.R., Manga, M., Sprain, C.J., Smit, J., Vanderkluysen, L., and Gibson, S.A. (2015) Triggering of the largest Deccan eruptions by the Chicxulub impact. GSA Bull 127:1507-1520.

Richardson, D.C., Bottke Jr, W.F., and Love, S.G. (1998) Tidal distortion and disruption of Earth-crossing asteroids. Icarus 134:47-76.

Riis, F., Kalleson, E., Dypvik, H., Krøgli, S.O., and Nilsen, O. (2011) The Ritland impact structure, southwestern Norway. Meteorit Planet Sci 46:748-761.

Robertson, D.S., Lewis, W.M., Sheehan, P.M., and Toon, O.B. (2013) K-Pg extinction: reevaluation of the heat-fire hypothesis. J Geophys Res Biogeosci 118:329-336.

Robin, E., Swinburne, N.H., Froget, L., Rocchia, R., and Gayraud, J. (1996) Characteristics and origin of the glass spherules from the Paleocene flood basalt province of western Greenland. Geochim Cosmochim Acta 60:815-830.

Rochette, P., Alaç, R., Beck, P., Brocard, G., Cavosie, A.J., Debaille, V., Devouard, B., Jourdan, F., Mougel, B., Moustard, F., and Moynier, F. (2019) Pantasma: evidence for a Pleistocene circa $14 \mathrm{~km}$ diameter impact crater in Nicaragua. Meteorit Planet Sci 54:880-901.

Roddick, J.C. (1978) The application of isochron diagrams in ${ }^{40} \mathrm{Ar}^{39} \mathrm{Ar}$ dating: a discussion. Earth Planet Sci Lett 41 : 233-244.
Romaña, A. and Cassidy, W.A. (1973) The Campo del Cielo, Argentina, meteorite crater field. Meteoritics 8:430-431.

Roperch, P., Gattacceca, J., Valenzuela, M., Devouard, B., Lorand, J.P., Arriagada, C., Rochette, P., Latorre, C., and Beck, P. (2017) Surface vitrification caused by natural fires in Late Pleistocene wetlands of the Atacama Desert. Earth Planet Sci Lett 469:15-26.

Rousell, D.H. and Brown, G.H. (2009) A Field Guide to the Geology of Sudbury, Ontario. Open File Report 6243, Ontario Geological Survey, Canada, 200 p.

Rummel, J.D., Beaty, D.W., Jones, M.A., Bakermans, C., Barlow, N.G., Boston, P.J., Chevrier, V.F., Clark, B.C., de Vera, J.P.P., Gough, R.V., Hallsworth, J.E., Head, J.W., Hipkin, V.J., Kieft, T.L., McEwen, A.S., Mellon, M.T., Mikucki, J.A., Nicholson, W.L., Omelon, C.R., Peterson, R., Roden, E.E., Sherwood Lollar, B., Tanaka, K.L., Viola, D., and Wray, J.J. (2014) A new analysis of Mars "special regions": findings of the second MEPAG Special Regions Science Analysis Group (SR-SAG2). Astrobiology 14: 887-968.

Russell, M.J. and Arndt, N.T. (2005) Geodynamic and metabolic cycles in the Hadean. Biogeoscience 2:97-111.

Russell, M.J. and Hall, A.J. (1997) The emergence of life from iron monosulphide bubbles at a submarine hydrothermal redox and pH front. J Geol Soc 154:377-402.

Ryder, G. (1990) Lunar samples, lunar accretion and the early bombardment of the Moon. Eos Trans AGU 71:313-323.

Ryder, G. (2002) Mass flux in the ancient Earth-Moon system and benign implications for the origin of life on Earth. J Geophys Res Planets 107:5022.

Salameh, E., Khoury, H., Reimold, W.U., and Schneider, W. (2008) The first large meteorite impact structure discovered in the Middle East: Jebel Waqf as Suwwan, Jordan. Meteorit Planet Sci 43:1681-1690.

Sapers, H.M., Banerjee, N.R., and Osinski, G.R. (2015) Potential for impact glass to preserve microbial metabolism. Earth Planet Sci Lett 430:95-104.

Sapers, H.M., Osinski, G.R., Banerjee, N.R., and Preston, L.J. (2014) Enigmatic tubular features in impact glass. Geology 42:471-474.

Sato, H., Onoue, T., Nozaki, T., and Suzuki, K. (2013) Osmium isotope evidence for a large Late Triassic impact event. Nat Commun 4:2455.

Schaller, M.F. and Fung, M.K. (2018) The extraterrestrial impact evidence at the Palaeocene-Eocene boundary and sequence of environmental change on the continental shelf. Phil Trans $R$ Soc A 376:20170081.

Schaller, M.F., Fung, M.K., Wright, J.D., Katz, M.E., and Kent, D.V. (2016) Impact ejecta at the Paleocene-Eocene boundary. Science 354:225-229.

Schaltegger, U., Schmitt, A.K., and Horstwood, M.S.A. (2015) $\mathrm{U}-\mathrm{Th}-\mathrm{Pb}$ zircon geochronology by ID-TIMS, SIMS, and laser ablation ICP-MS: recipes, interpretations, and opportunities. Chem Geol 402:89-110.

Schärer, U. and Deutsch, A. (1990) Isotope systematics and shock-wave metamorphism: II. U-Pb and $\mathrm{Rb}-\mathrm{Sr}$ in naturally shocked rocks; the Haughton Impact Structure, Canada. Geochim Cosmochim Acta 54:3435-3447.

Schenk, P.M., Asphaug, E., McKinnon, W.B., Melosh, H.J., and Weissman, P.R. (1996) Cometary nuclei and tidal disruption: the geologic record of crater chains on Callisto and Ganymede. Icarus 121:249-274.

Schieber, J. and Over, D.J. (2005) Sedimentary fill of the Late Devonian Flynn Creek Crater: a hard target marine impact. In 
Understanding Late Devonian and Permian-Triassic Biotic and Climatic Events-Towards an Integrated Approach, edited by D.J. Over, J.R. Morrow, and P.B. Wignall, Elsevier, Development of Palaeontology Strata, Vol. 20, Elsevier, Amsterdam; San Diego, CA, pp 51-69.

Schmidt, G. and Pernicka, E. (1994) The determination of platinum group elements (PGE) in target rocks and fall-back material of the Nördlinger Ries impact crater, Germany. Geochim Cosmochim Acta 58:5083-5090.

Schmidt, G., Palme, H., and Kratz, K.L. (1997) Highly siderophile elements ( $\mathrm{Re}, \mathrm{Os}, \mathrm{Ir}, \mathrm{Ru}, \mathrm{Rh}, \mathrm{Pd}, \mathrm{Au}$ ) in impact melts from three European impact craters (Sääksjärvi, Mien, and Dellen): clues to the nature of the impacting bodies. Geochim Cosmochim Acta 61:2977-2987.

Schmieder, M., Trieloff, M., Schwarz, W.H., Buchner, E., and Jourdan, F. (2014c) Supportive comment on: "Morphology and population of binary asteroid impact craters," by $\mathrm{K}$. Miljkovic, GS Collins, S. Mannick and PA Bland [Earth Planet. Sci. Lett. 363 (2013) 121-132]—an updated assessment. Earth Planet Sci Lett 405:281-284.

Schmieder, M. and Buchner, E. (2008) Dating impact craters: palaeogeographic versus isotopic and stratigraphic methods-a brief case study. Geol Mag 145:586-590.

Schmieder, M. and Buchner, E. (2013) Impaktereignisse in Europa (Impact events in Europe). German J Geol 164:387415.

Schmieder, M. and Jourdan, F. (2013a) The Lappajärvi impact structure (Finland): age, duration of crater cooling, and implications for early life. Geochim Cosmochim Acta 112: 321-339.

Schmieder, M. and Jourdan, F. (2013b) Cosmic hotspots for life. Aust Sci 34:16-20.

Schmieder, M., Buchner, E., Jourdan, F., Schwarz, W.H., Trieloff, M., van Soest, M.C., Wartho, J.A., Hodges, K.V., Moilanen, J., Hietala, S., and Öhman, T. (2010a) Updating the Finnish impact cratering record [abstract 2036]. In Lunar and Planetary Science XLI. Lunar and Planetary Institute, Houston, TX.

Schmieder, M., Buchner, E., Schwarz, W.H., Trieloff, M., and Lambert, P. (2010b) A Rhaetian ${ }^{40} \mathrm{Ar} /{ }^{39} \mathrm{Ar}$ age for the Rochechouart impact structure (France) and implications for the latest Triassic sedimentary record. Meteorit Planet Sci 45: 1225-1242.

Schmieder, M., Schwarz, W.H., Buchner, E., Trieloff, M., Moilanen, J., and Öhman, T. (2010c) A Middle-Late Triassic ${ }^{40} \mathrm{Ar} /{ }^{39} \mathrm{Ar}$ age for the Paasselkä impact structure (SE Finland). Meteorit Planet Sci 45:572-582.

Schmieder, M., Seyfried, H., and Gerel, O. (2013) The circular Uneged Uul structure (East Gobi Basin, Mongolia)geomorphic and structural evidence for meteorite impact into an unconsolidated coarse-clastic target? J Asian Earth Sci 64:58-76.

Schmieder, M., Jourdan, F., Tohver, E., and Cloutis, E.A. (2014a) ${ }^{40} \mathrm{Ar} /{ }^{39} \mathrm{Ar}$ age of the Lake Saint Martin impact structure (Canada) — unchaining the Late Triassic terrestrial impact craters. Earth Planet Sci Lett 406:37-48.

Schmieder, M., Jourdan, F., Öhman, T., Tohver, E., Mayers, C., and Frew, A. (2014b) A Proterozoic ${ }^{40} \mathrm{Ar} /{ }^{39} \mathrm{Ar}$ age for the Söderfjärden impact structure, Finland [abstract 1301]. In Lunar and Planetary Science XLV. LPI, Houston, TX.

Schmieder, M., Trieloff, M., Schwarz, W.H., Buchner, E., and Jourdan, F. (2014c) Supportive comment on: "Morphology and population of binary asteroid impact craters," by $\mathrm{K}$.
Miljkovic, GS Collins, S. Mannick and PA Bland [Earth Planet. Sci. Lett. 363 (2013) 121-132] - an updated assessment. Earth Planet Sci Lett 405:281-284.

Schmieder, M., Schwarz, W.H., Trieloff, M., Tohver, E., Buchner, E., Hopp, J., and Osinski, G.R. (2015a) New ${ }^{40} \mathrm{Ar} /{ }^{39} \mathrm{Ar}$ dating of the Clearwater Lake impact structures (Québec, Canada)—not the binary asteroid impact it seems? Geochim Cosmochim Acta 148:304-324.

Schmieder, M., Tohver, E., Jourdan, F., Denyszyn, S.W., and Haines, P.W. (2015b) Zircons from the Acraman impact melt rock (South Australia): shock metamorphism, U-Pb and ${ }^{40} \mathrm{Ar} /{ }^{39} \mathrm{Ar}$ systematics, and implications for the isotopic dating of impact events. Geochim Cosmochim Acta 161:71-100.

Schmieder, M., Jourdan, F., Moilanen, J., Buchner, E., and Öhman, T. (2016a) A Late Mesoproterozoic ${ }^{40} \mathrm{Ar} /{ }^{39} \mathrm{Ar}$ age for a melt breccia from the Keurusselkä impact structure, Finland. Meteorit Planet Sci 51:303-322.

Schmieder, M., Schwarz, W.H., Trieloff, M., Buchner, E., Hopp, J., Tohver, E., Pesonen, L.J., Lehtinen, M., Moilanen, J., Werner, S.C., and Öhman, T. (2016b) The two Suvasvesi impact structures, Finland: argon isotopic evidence for a "false" impact crater doublet. Meteorit Planet Sci 51:966-980.

Schmieder, M., Kennedy, T., Jourdan, F., Buchner, E., and Reimold, W.U. (2018a) A high-precision ${ }^{40} \mathrm{Ar} /{ }^{39} \mathrm{Ar}$ age for the Nördlinger Ries impact crater, Germany, and implications for the accurate dating of terrestrial impact events. Geochim Cosmochim Acta 220:146-157.

Schmieder, M., Kennedy, T., Jourdan, F., Buchner, E., and Reimold, W.U. (2018b) Response to comment on "A highprecision ${ }^{40} \mathrm{Ar} /{ }^{39} \mathrm{Ar}$ age for the Nördlinger Ries impact crater, Germany, and implications for the accurate dating of terrestrial impact events" by Schmieder et al.(Geochimica et Cosmochimica Acta 220 (2018) 146-157). Geochim Cosmochim Acta 238:602-605.

Schmieder, M., Shaulis, B.J., Lapen, T.J., Buchner, E., and Kring, D.A. (2019) In situ U-Pb analysis of shocked zircon from the Charlevoix impact structure, Québec, Canada. Meteorit Planet Sci 54:1808-1827.

Schmitz, B. (2013) Extraterrestrial spinels and the astronomical perspective on Earth's geological record and evolution of life. Geochrmistry 73:117-145.

Schmitz, B., Lindström, M., Asaro, F., and Tassinari, M. (1996) Geochemistry of meteorite-rich marine limestone strata and fossil meteorites from the lower Ordovician at Kinnekulle, Sweden. Earth Planet Sci Lett 145:31-48.

Schmitz, B., Tassinari, M., and Peucker-Ehrenbrink, B. (2001) A rain of ordinary chondritic meteorites in the early Ordovician. Earth Planet Sci Lett 194:1-15.

Schmitz, B., Harper, D.A., Peucker-Ehrenbrink, B., Stouge, S., Alwmark, C., Cronholm, A., Bergström, S.M., Tassinari, M., and Xiaofeng, W. (2008) Asteroid breakup linked to the Great Ordovician biodiversification event. Nat Geosci 1: 49-53.

Schmitz, B., Boschi, S., Cronholm, A., Heck, P.R., Monechi, S., Montanari, A., and Terfelt, F. (2015) Fragments of Late Eocene Earth-impacting asteroids linked to disturbance of asteroid belt. Earth Planet Sci Lett 425:77-83.

Schoene, B. (2014) Chapter 4.10: U-Th-Pb geochronology. In Treatise on Geochemistry, edited by H.D. Holland and K. K. Turekian, Elsevier, Amsterdam; Heidelberg, Germany, pp 341-378.

Schulte, P., Alegret, L., Arenillas, I., Arz, J.A., Barton, P.J., Bown, P.R., Bralower, T.J., Christeson,G.L., Claeys, P.H., 
Cockell, C.S., Collins, G.S., Deutsch, A., Goldin, T.J., Goto, K., Grajales-Nishimura, J.M., Grieve, R.A.F., Gulick, S.P.S., Johnson, K.R., Kiessling, W., Koeberl, C., Kring, D.A., MacLeod, K.G., Matsui, T., Melosh, J.,Montanari, A., Morgan, J.V., Neal, C.R., Nichols, D.J., Norris, R.D., Pierazzo, E., Ravizza, G., Rebolledo-Vieyra, M., Reimold, W.U., Robin, E., Salge, T., Speijer, R.P., Sweet, A.R., UrrutiaFucugauchi, J., Vajda, V., Whalen, M.T., and Willumsen, P.S. (2010) The Chicxulub asteroid impact and mass extinction the Cretaceous-Paleogene boundary. Science 327: 1214-1218.

Schultz, P.H. and Lianza, R.E. (1992) Recent grazing impacts on the Earth recorded in the Rio Cuarto crater field, Argentina. Nature 355:234-237.

Schultz, P.H., Zarate, M., Hames, W., Camilión, C., and King, J. (1998) A 3.3-Ma impact in Argentina and possible consequences. Science 282:2061-2063.

Schultz, P.H., Zárate, M., Hames, B., Koeberl, C., Bunch, T., Storzer, D., Renne, P., and Wittke, J. (2004) The Quaternary impact record from the Pampas, Argentina. Earth Planet Sci Lett 219:221-238.

Schultz, P.H., Zárate, M., Hames, W.E., Harris, R.S., Bunch, T.E., Koeberl, C., Renne, P., and Wittke, J. (2006) The record of Miocene impacts in the Argentine Pampas. Meteorit Planet Sci 41:749-771.

Schultze, D.S., Jourdan, F., Hecht, L., Reimold, W.U., and Schmitt, R.T. (2016) Tenoumer impact crater, Mauritania: impact melt genesis from a lithologically diverse target. Meteorit Planet Sci 51:323-350.

Schwarz, W.H., Schmieder, M., Buchner, E., Trieloff, M., Moilanen, J., and Öhman, T. (2015) A Carnian ${ }^{40} \mathrm{Ar} /{ }^{39} \mathrm{Ar}$ age for the Paasselkä impact structure (SE Finland) —an update. Meteorit Planet Sci 50:135-140.

Schwarz, W.H., Breutmann, G., Schmitt, A.K., Trieloff, M., Ludwig, T., Hanel, M., Buchner, E., Schmieder, M., Pesonen, L.J., and Moilanen, J. (August 7-12, 2016a) U/Pb dating of zircon from the Suvasvesi impact structures, Finland [abstract 6297]. In 79th Annual Meeting of the Meteoritical Society, Berlin, Germany. LPI Contribution No. 1921. Lunar and Planetary Institute, Houston, TX.

Schwarz, W.H., Trieloff, M., Bollinger, K., Gantert, N., Fernandes, V.A., Meyer, H.P., Povenmire, H., Jessberger, E.K., Guglielmino, M., and Koeberl, C. (2016b) Coeval ages of Australasian, Central American and Western Canadian tektites reveal multiple impacts 790 ka ago. Geochim Cosmochim Acta 178:307-319.

Schwenzer, S.P. and Kring, D.A. (2009) Impact-generated hydrothermal systems capable of forming phyllosilicates on Noachian Mars. Geology 37:1091-1094.

Scotese, C.R. (2001) Paleomap Project. Available online at www.scotese.com (accessed April 19, 2019).

Scott, R.G., Pilkington, M., and Tanczyk, E.I. (1997) Magnetic investigations of the West Hawk, Deep Bay and Clearwater impact structures, Canada. Meteorit Planet Sci 32:293-308.

Sepkoski, J.J. (1996) Patterns of Phanerozoic extinction: a perspective from global data bases. In Global Events and Event Stratigraphy in the Phanerozoic, edited by O.H. Walliser, Springer, Berlin, Heidelberg, pp 35-51.

Sharpton, V.L. and Gibson, J.W., Jr. (1990) The Marquez Dome impact structure, Leon County, Texas. In Lunar and Plane- tary Science XXI, Lunar and Planetary Institute, Houston, TX, pp 1136-1137.

Sharpton, V.L., Copeland, P., Dressler, B.O., and Spell, T.L. (1997) New age constraints on the Slate Islands impact structure, Lake Superior, Canada. In Lunar and Planetary Science XXVIII, Lunar and Planetary Institute, Houston, TX, pp 1287-1288.

Shen, S.Z., Crowley, J.L., Wang, Y., Bowring, S.A., Erwin, D.H., Sadler, P.M., Cao, C.Q., Rothman, D.H., Henderson, C.M., Ramezani, J., and Zhang, H. (2011) Calibrating the end-Permian mass extinction. Science 334:1367-1372.

Sheppard, S., Johnson, S.P., Wingate, M.T.D., Kirkland, C.L., and Pirajno, F. (2010) Explanatory Notes for the Gascoyne Province. Geological Survey of Western Australia, East Perth, Western Australia, 336 p.

Sherlock, S.C., Kelley, S.P., Glazovskaya, L., and Peate, I.U. (2009) The significance of the contemporaneous Logoisk impact structure (Belarus) and Afro-Arabian flood volcanism. J Geol Soc 166:5-8.

Shoemaker, E.M. (1960) Penetration mechanics of high velocity meteorites, illustrated by Meteor crater, Arizona. In 21st International Geological Congress, Copenhagen, pp 418-434.

Shoemaker, E.M. (1983) Asteroid and comet bombardment of the Earth. Ann Rev Earth Planet Sci 11:461-494.

Shoemaker, E.M. (1998a) Impact cratering through geologic time. J R Astronom Soc Canada 92:297-309.

Shoemaker, E.M. (1998b) Long-term variations in the impact cratering rate on Earth. Geol Soc London Spec Pub 140: $7-10$.

Shoemaker, E.M. and Shoemaker, C.S. (1985) Impact structures of Western Australia. Meteoritics 20:754-755.

Shoemaker, E.M. and Shoemaker, C.S. (1986) Connolly Basin: a probable eroded impact crater in Western Australia. In Lunar and Planetary Science XVII, Lunar and Planetary Institute, Houston, TX, pp 797-798.

Shoemaker, E.M. and Shoemaker, C.S. (1988) Impact structures of Australia (1987). In Lunar and Planetary Science XIX, Lunar and Planetary Institute, Houston, TX, pp 1079-1080.

Shoemaker, E.M. and Shoemaker, C.S. (1997) Notes on the geology of Liverpool crater, Northern Territory, Australia. In Lunar and Planetary Science XXVIII, Lunar and Planetary Institute, Houston, TX, pp 1311-1312.

Shoemaker, E.M., Williams, J.G., Helin, E.F., and Wolfe, R.F. (1979) Earth-crossing asteroids: orbital classes, collision rates with Earth, and origin. Asteroids 1:253-282.

Shoemaker, E.M., Shoemaker, C.S., Nishiizumi, K., Kohl, C.P., Arnold, J.R., Klein, J., Fink, D., Middleton, R., Kubik, P.W., and Sharma, P. (1990) Ages of Australian meteorite cratersa preliminary report. Meteoritics 25:409.

Shoemaker, E.M., Macdonald, F.A., and Shoemaker, C.S. (2005) Geology of five small Australian impact craters. Aust J Earth Sci 52:529-544.

Sighinolfi, G.P., Sibilia, E., Contini, G., and Martini, M. (2015) Thermoluminescence dating of the Kamil impact crater (Egypt). Meteorit Planet Sci 50:204-213.

Simms, M.J. (2003) Uniquely extensive seismite from the latest Triassic of the United Kingdom: evidence for bolide impact? Geology 31:557-560.

Simms, M.J. (2007) Uniquely extensive soft-sediment deformation in the Rhaetian of the UK: evidence for earthquake or 
impact? Palaeogeogr Palaeoclimatol Palaeoecol 244:407423.

Simonds, C.H., Phinney, W.C., McGee, P.E., and Cochran, A. (1978) West Clearwater, Quebec impact structure. I-Field geology, structure and bulk chemistry. II-Petrology. Proc Lunar Planet Sci Conf 9:2633-2693.

Simonson, B.M., Davies, D., and Hassler, S.W. (2000) Discovery of a layer of probable impact melt spherules in the Late Archaean Jeerinah Formation, Fortescue Group, Western Australia. Aust J Earth Sci 47:315-325.

Simonson, B.M., Sumner, D.Y., Beukes, N.J., Johnson, S., and Gutzmer, J. (2009) Correlating multiple NeoarcheanPaleoproterozoic impact spherule layers between South Africa and Western Australia. Precambrian Research, 169:100-111.

Simpson, S.L., Boyce, A.J., Lambert, P., Lindgren, P., and Lee, M.R. (2017) Evidence for an impact-induced biosphere from the $\delta^{34} \mathrm{~S}$ signature of sulphides in the Rochechouart impact structure, France. Earth Planet Sci Lett 460:192-200.

Sleep, N.H., Zahnle, K.J., Kasting, J.F., and Morowitz, H.J. (1989) Annihilation of ecosystems by large asteroid impacts on the early Earth. Nature 342:139-142.

Smelror, M., Kelly, S.R., Dypvik, H., Mørk, A., Nagy, J., and Tsikalas, F. (2001) Mjølnir (Barents Sea) meteorite impact ejecta offers a Volgian-Ryazanian boundary marker. Newslett Strat 38:129-140.

Smit, J. (1999) The global stratigraphy of the CretaceousTertiary boundary impact ejecta. Ann Rev Earth Planet Sci 27:75-113.

Smit, J. and Hertogen, J. (1980) An extraterrestrial event at the Cretaceous-Tertiary boundary. Nature 285:198-200.

Smit, J. and Romein, A.J.T. (1985) A sequence of events across the Cretaceous-Tertiary boundary. Earth Planet Sci Lett 74: $155-170$.

Smith, R. (2011) Dark days of the Triassic: lost world. Nat News 479:287-289.

Snyder, F.G. and Gerdemann, P.E. (1965) Explosive igneous activity along an Illinois-Missouri-Kansas axis. Am J Sci 263 : 465-493.

Sprain, C.J. (2017) Resolving the timing of events around the Cretaceous-Paleogene boundary. Doctoral dissertation, UC Berkeley, University of California, Berkeley, CA, $156 \mathrm{p}$.

Sprain, C.J., Renne, P.R., Wilson, G.P., and Clemens, W.A. (2015) High-resolution chronostratigraphy of the terrestrial Cretaceous-Paleogene transition and recovery interval in the Hell Creek region, Montana. GSA Bull 127:393-409.

Sprain, C.J., Renne, P.R., Clemens, W.A., and Wilson, G.P. (2018) Calibration of chron C29r: new high-precision geochronologic and paleomagnetic constraints from the Hell Creek region, Montana. GSA Bull 130:1615-1644.

Spray, J.G., Kelley, S.P., and Rowley, D.B. (1998) Evidence for a late Triassic multiple impact event on Earth. Nature 392: 171-173.

Spray, J.G., Kelley, S.P., and Dence, M.R. (1999) The Strangways impact structure, Northern Territory, Australia: geological setting and laser probe ${ }^{40} \mathrm{Ar} /{ }^{39} \mathrm{Ar}$ geochronology. Earth Planet Sci Lett 172:199-211.

Spray, J.G., Thompson, L.M., Biren, M.B., and O'ConnellCooper, C. (2010) The Manicouagan impact structure as a terrestrial analogue site for lunar and martian planetary science. Planet Space Sci 58:538-551.

Spudis, P.D. (1993) The Geology of Multi-Ring Impact Basins-The Moon and Other Planets. Cambridge University Press, Cambridge, UK, $280 \mathrm{p}$.
Stankowski, W., Raukas, A., Bluszcz, A., and Fedorowicz, S. (2007) Luminescence dating of the Morasko (Poland), kaali, ilumetsa and Tsõorikmäe (Estonia) meteorite craters. Geochronometria 28:25-29.

Steiger, R. and Jäger, E. (1977) Subcommission on geochronology: convention on the use of decay constants in geo-and cosmochronology. Earth Planet Sci Lett 36:359-362.

Stockli, D.F., Farley, K.A., and Dumitru, T.A. (2000) Calibration of the apatite (U-Th)/He thermochronometer on an exhumed fault block, White Mountains, California. Geology 28: 983-986.

Stockli, D.F., Rasmussen, C., Ross, C., Stockli, L.D., Gulick, S.P.S., Chatterjee, R., Christeson, G.L., Wittmann, A., Schmieder, M., Kring, D.A., Xiao, L., and Morgan, J.V.; the Expedition 364 Science Party, IODP-ICDP. (2018) Zircon and apatite U$\mathrm{Pb}$ and $(\mathrm{U}-\mathrm{Th}) / \mathrm{He}$ geo- and thermochronometry of the crystalline basement in Chicxulub's peak ring structure (IODP Exp. 364). GSA Abstr. w/Progr. 50, no. 6. DOI: 10.1130/abs/ 2018AM-320351. https://gsa.confex.com/gsa/2018AM/webprogram/Paper320351.html

Stöffler, D. and Grieve, R.A.F. (2007) Impactites. In Metamorphic Rocks-A Classification and Glossary of Terms, Recommendations of the International Union of Geological Sciences, Subcommission on the Systematics of Metamorphic Rocks, edited by D. Fettes and J. Desmons, Cambridge University Press, Cambridge, UK, pp 82-92.

Stöffler, D., Deutsch, A., Avermann, M., Bischoff, L., Brockmeyer, P., Buhl, D., Lakomy, R., and Müller-Mohr, V. (1994) The formation of the Sudbury Structure, Canada: toward a unified impact model. In Large Meteorite Impacts and Planetary Evolution, GSA Special Paper 293, edited by B.O. Dressler, R.A.F. Grieve, and V.L. Sharpton, Boulder, $\mathrm{CO}$, Geological Society of America, Boulder, CO, pp 303318.

Stöffler, D., Artemieva, N.A., and Pierazzo, E. (2002) Modeling the Ries-Steinheim impact event and the formation of the moldavite strewn field. Meteorit Planet Sci 37:1893-1907.

Stöffler, D., Ryder, G., Ivanov, B.A., Artemieva, N.A., Cintala, M.J., and Grieve, R.A. (2006) Cratering history and lunar chronology. Rev Mineral Geochem 60:519-596.

Stöffler, D., Artemieva, N.A., Wünnemann, K., Reimold, W.U., Jacob, J., Hansen, B.K., and Summerson, I.A. (2013) Ries crater and suevite revisited-observations and modeling Part I: observations. Meteorit Planet Sci 48:515-589.

Stone, D.S. and Therriault, A.M. (2003) Cloud Creek structure, central Wyoming, USA: impact origin confirmed. Meteorit Planet Sci 38:445-455.

Storzer, D., Reimold, W.U., and Koeberl, C. (1999) Fissiontrack age of the Pretoria Saltpan impact crater. In Tswaing: Investigation into the Origin, Age and Paleoenvironements of the Pretoria Saltpan, edited by T.C. Patridge, Council for Geoscience, Geological Survey of South Africa, Pretoria, South Africa, pp 64-71.

Stuart, J.S. and Binzel, R.P. (2004) Bias-corrected population, size distribution, and impact hazard for the near-Earth objects. Icarus 170:295-311.

Sturkell, E., Ormö, J., Nõlvak, J., and Wallin, Å. (2000) Distant ejecta from the Lockne marine-target impact crater, Sweden. Meteorit Planet Sci 35:929-936.

Sutton, S.R. (1985) Thermoluminescence measurements on shock-metamorphosed sandstone and dolomite from Meteor Crater, Arizona: 2. Thermoluminescence age of meteor crater. J Geophys Res Solid Earth 90:3690-3700. 
Suuroja, K. and Suuroja, S. (2000) Neugrund structure-the newly discovered submarine early Cambrian impact crater. In Impacts and the Early Earth, edited by I. Gilmour and C. Koeberl, Springer, Berlin, Heidelberg, pp 389-416.

Svetsov, V.V. and Shuvalov, V.V. (2015) Water delivery to the Moon by asteroidal and cometary impacts. Planet Space Sci 117:444-452.

Swindle, T.D., Kring, D.A., and Weirich, J.R. (2014) ${ }^{40} \mathrm{Ar} /{ }^{39} \mathrm{Ar}$ ages of impacts involving ordinary chondrite meteorites. In Advances in ${ }^{40} \mathrm{Ar} /{ }^{39} \mathrm{Ar}$ Dating: From Archaeology to Planetary Sciences, edited by F. Jourdan, D.F. Mark, and C. Verati, Geological Society London Special Publications, Vol. 378, London, UK, pp 333-347.

Swisher, C.C., Grajales-Nishimura, J.M., Montanari, A., Margolis, S.V., Claeys, P.H., Alvarez, W., Renne, P., CedilloPardoa, E., Maurrasse, F.J.R., Curtis, G.H., and Smit, J. (1992) Coeval ${ }^{40} \mathrm{Ar} /{ }^{39} \mathrm{Ar}$ ages of 65.0 million years ago from Chicxulub crater melt rock and Cretaceous-Tertiary boundary tektites. Science 257:954-958.

Sylvester, P., Crowley, J., and Schmitz, M. (August 25-30, 2013) U-Pb zircon age of Mistastin Lake Crater, Labrador, Canada-implications for high-precision dating of small impact melt sheets and the end eocene extinction, Goldschmidt, Florence, Italy, Conference. Mineral Mag 77:2295.

Tagle, R. and Claeys, P.H. (2004) Comet or asteroid shower in the late Eocene? Science 305:492.

Tagle, R. and Claeys, P.H. (2005) An ordinary chondrite impactor for the Popigai crater, Siberia. Geochim Cosmochim Acta 69:2877-2889.

Tagle, R. and Hecht, L. (2006) Geochemical identification of projectiles in impact rocks. Meteorit Planet Sci 41:17211735.

Tagle, R., Claeys, P.H., Grieve, R.A.F., Schmitt, R.T., and Erzinger, J. (2006) Evidence for a second L Chondrite impact in the Late Eocene: preliminary results from the Wanapitei Crater, Canada [abstract 1278]. In Lunar and Planetary Science XXXVII. Lunar and Planetary Institute, Houston, TX.

Tagle, R., Schmitt, R.T., and Erzinger, J. (2009). Identification of the projectile component in the impact structures Rochechouart, France and Sääksjärvi, Finland: implications for the impactor population for the earth. Geochim Cosmochim Acta, 73:4891-4906.

Tancredi, G., Ishitsuka, J., Schultz, P.H., Harris, R.S., Brown, P., Revelle, D.O., Antier, K., Pichon, A.L., Rosales, D., Vidal, E., and Varela, M.E. (2009) A meteorite crater on Earth formed on September 15, 2007: the Carancas hypervelocity impact. Meteorit Planet Sci 44:1967-1984.

Tanner, L.H., Lucas, S.G., and Chapman, M.G. (2004) Assessing the record and causes of Late Triassic extinctions. Earth Sci Rev 65:103-139.

Telecka, M. and Matyjasek, J. (2011) Paleopositions of the chains of the meteorite craters on the Earth. Ann Univ Mariae Curie-Sklodowska 66:53-62.

Tera, F. and Wasserburg, G.J. (1972) U-Th-Pb systematics in three Apollo 14 basalts and the problem of initial $\mathrm{Pb}$ in lunar rocks. Earth Planet Sci Lett 14:281-304.

Tera, F. and Wasserburg, G.J. (1974) U-Th-Pb systematics on lunar rocks and inferences about lunar evolution and the age of the moon. Proc Lunar Planet Sci Conf 5:1571-1599.

Tera, F., Papanastassiou, D.A., and Wasserburg, G.J. (1974) Isotopic evidence for a terminal lunar cataclysm. Earth Planet Sci Lett 22:1-21.
Therriault, A.M., Grieve, R.A.F., and Reimold, W.U. (1997) Original size of the Vredefort structure: implications for the geological evolution of the Witwatersrand Basin. Meteorit Planet Sci 32:71-77.

Timms, N.E., Erickson, T.M., Pearce, M.A., Cavosie, A.J., Schmieder, M., Tohver, E., Reddy, S.M., Zanetti, M.R., Nemchin, A.A., and Wittmann, A. (2017) A pressuretemperature phase diagram for zircon at extreme conditions. Earth Sci Rev 165:185-202.

Tohver, E., Lana, C., Cawood, P.A., Fletcher, I.R., Jourdan, F., Sherlock, S., Rasmussen, B., Trindade, R.I.F.D., Yokoyama, E., Souza Filho, C.R., and Marangoni, Y. (2012) Geochronological constraints on the age of a Permo-Triassic impact event: $\mathrm{U}-\mathrm{Pb}$ and ${ }^{40} \mathrm{Ar} /{ }^{39} \mathrm{Ar}$ results for the $40 \mathrm{~km}$ Araguainha structure of central Brazil. Geochim Cosmochim Acta 86:214-227.

Tohver, E., Cawood, P.A., Riccomini, C., Lana, C., and Trindade, R.I.F.D. (2013) Shaking a methane fizz: seismicity from the Araguainha impact event and the Permian-Triassic global carbon isotope record. Palaeogeogr Palaeoclimatol Palaeoecol 387:66-75.

Tohver, E., Schmieder, M., Lana, C., Mendes, P.S., Jourdan, F., Warren, L., and Riccomini, C. (2018) End-Permian impactogenic earthquake and tsunami deposits in the intracratonic Paraná Basin of Brazil. GSA Bull 130:1099-1120.

Toon, O.B., Zahnle, K., Morrison, D., Turco, R.P., and Covey, C. (1997) Environmental perturbations caused by the impacts of asteroids and comets. Rev Geophys 35:41-78.

Torbett, M.V. and Smoluchowski, R. (1984) Orbital stability of the unseen solar companion linked to periodic extinction events. Nature 311:641-642.

Trieloff, M., Deutsch, A., and Jessberger, E.K. (1998) The age of the Kara impact structure, Russia. Meteorit Planet Sci 33: 361-372.

Trnka, M. and Houzar, S. (2002) Moldavites: a review. Bull Czech Geol Surv 77:283-302.

Turner, G., Cadogan, P.H., and Yonge, C.J. (1973) Argon selenochronology. In Proceedings of the Fourth Lunar Science Conference (Supplement 4, Geochimica et Cosmochimica Acta) Vol 2., pp 1889-1914.

Ukstins Peate, I., van Soest, M.C., Wartho, J.A., Cabrol, N., Grin, E., Piatek, J., Piatek, J., and Chong, G. (2010) A novel application of (U-Th)/He geochronology to constrain the age of small, young meteorite impact craters: a case study of the Monturaqui Crater, Chile [abstract 2161]. In Lunar and Planetary Science XLI. LPI Contribution No. 1533. Lunar and Planetary Institute, Houston, TX.

Val'ter, A.A., Ryabenko, V.A., and Kotlovskaya, F.I. (1981) The Ternovka astrobleme: new and most deeply eroded meteorite crater on the Ukrainian shield. Doklady Akad Nauk SSSR 2:3-7.

van Soest, M.C., Hodges, K.V., Wartho, J.A., Biren, M.B., Monteleone, B.D., Ramezani, J., Spray, J.G., and Thompson, L.M. (2011) (U-Th)/He dating of terrestrial impact structures: the Manicouagan example. Geochem Geophys Geosyst 12: Q0AA16.

Vellekoop, J., Sluijs, A., Smit, J., Schouten, S., Weijers, J.W., Damsté, J.S.S., and Brinkhuis, H. (2014) Rapid short-term cooling following the Chicxulub impact at the CretaceousPaleogene boundary. Proc Natl Acad Sci U S A 111:7537-7541. Vellekoop, J., Esmeray-Senlet, S., Miller, K.G., Browning, J.V., Sluijs, A., van de Schootbrugge, B., Damsté, J.S.S., and Brinkhuis, H. (2016) Evidence for Cretaceous-Paleogene 
boundary bolide "impact winter" conditions from New Jersey, USA. Geology 44:619-622.

Villeneuve, M., Sandeman, H.A., and Davis, W.J. (2000) A method for intercalibration of U-Th-Pb and ${ }^{40} \mathrm{Ar}-{ }^{39} \mathrm{Ar}$ ages in the Phanerozoic. Geochim Cosmochim Acta 64:4017-4030.

Vishnevsky, S.A. (1995) The Chykcha impact crater, Taymyr Peninsula: a heavily eroded astrobleme of (K2-Pg1)? age. Meteoritics 30:591.

Vishnevsky, S.A. (1999) Ragozinka: eocenian marine impact crater on the middle Urals, Russia. Meteorit Planet Sci Suppl 34:A117.

Vishnevsky, S.A. (2007) Shiyli Dome, Kazakhstan: origin of central uplift by elastic response [abstract 8013]. In Bridging the Gap II: Effect of Target Properties on the Impact Cratering Process Conference, Lunar and Planetary Institute, Houston, TX, pp 125-126. LPI Contribution No. 1360.

von Engelhardt, W. (1984) Melt products from terrestrial impact structures. Proc Int Geol Congr 19:149-163.

von Engelhardt, W. (1997) Suevite breccia of the Ries impact crater, Germany: petrography, chemistry and shock metamorphism of crystalline rock clasts. Meteorit Planet Sci 32: 545-554.

von Engelhardt, W., Arndt, J., Fecker, B., and Pankau, H.G. (1995) Suevite breccia from the Ries crater, Germany: origin, cooling history and devitrification of impact glasses. Meteoritics 30:279-293.

Walkden, G., and Parker, J. (2008) The biotic effects of large bolide impacts: size versus time and place. Int J Astrobiol 7: 209-215.

Walkden, G., Parker, J., and Kelley, S. (2002) A Late Triassic impact ejecta layer in southwestern Britain. Science 298: 2185-2188.

Wang, G., Zhan, R., and Percival, I.G. (2019) The endOrdovician mass extinction: a single-pulse event? Earth Sci Rev 192:15-33.

Wang, K. and Chatterton, B.D.E. (1993) Microspherules in Devonian sediments: origins, geological significance, and contamination problems. Can J Earth Sci 30:1660-1667.

Wänke, H. and König, H. (1959) Eine neue Methode zur Kalium-Argon-Altersbestimmung und ihre Anwendung auf Steinmeteorite. Zeitschr Naturforsch A 14:860-866.

Wartho, J.A., van Soest, M.C., King Jr, D.T., and Petruny, L.W. (2012) An (U-Th)/He age for the shallow-marine Wetumpka impact structure, Alabama, USA. Meteorit Planet Sci 47: 1243-1255.

Weber, J.C., Poulos, C., Donelick, R.A., Pope, M.C., and Heller, N. (2005) The Kentland impact crater, Indiana (USA): an apatite fission-track age determination attempt. In Impact Tectonics, edited by C. Koeberl and H. Henkel, Springer, Berlin, Heidelberg, pp 447-466.

Weissman, P.R. (1990) The cometary impactor flux at the Earth. In Global Catastrophes in Earth History; An Interdisciplinary Conference on Impacts, Volcanism, and Mass Mortality, GSA Special Paper 247, edited by V.L. Sharpton and P.D. Ward, Boulder, CO, Geological Society of America, Boulder, CO, pp 171-180.

Werner, S.C., Plado, J., Pesonen, L.J., and Kuulusa, M. (2001) The two Suvasvesi Lakes in Central Finland-a possible doublet impact structure. Meteorit Planet Sci 36:A223-A224.
Werner, S.C., Harris, A.W., Neukum, G., and Ivanov, B.A. (2002) The near-Earth asteroid size-frequency distribution: a snapshot of the lunar impactor size-frequency distribution. Icarus 156:287-290.

Westall, F., Hickman-Lewis, K., Hinman, N., Gautret, P., Campbell, K.A., Bréhéret, J.G., Foucher, F., Hubert, A., Sorieul, S., Dass, A.V., and Kee, T.P. (2018) A hydrothermalsedimentary context for the origin of life. Astrobiology 18: 259-293.

Wetherill, G.W. (1956) Discordant uranium-lead ages, I. Eos Trans AGU 37:320-326.

Wetherill, G.W. (1963) Discordant uranium-lead ages: 2. Discordant ages resulting from diffusion of lead and uranium. $J$ Geophys Res 68:2957-2965.

Wheeler, L.F. and Mathias, D.L. (2019) Effects of asteroid property distributions on expected impact rates. Icarus 321: 767-777.

Whitehead, J., Papanastassiou, D.A., Spray, J.G., Grieve, R.A.F., and Wasserburg, G.J. (2000) Late Eocene impact ejecta: geochemical and isotopic connections with the Popigai impact structure. Earth Planet Sci Lett 181:473487.

Whitehead, J., Kelley, S., Sherlock, S.C., Grieve, R.A.F., Spray, J.G., and Trepmann, C.A. (August 5-7, 2003) Structural and geochronologic constraints on the timing of the Charlevoix impact, Quebec, Canada [abstract 4084]. In Large Meteorite Impacts III Conference, Nördlingen, Germany. Lunar and Planetary Institute, Houston, TX.

Wichman, R.W. and Wood, C.A. (1995) The Davy Crater Chain: implications for tidal disruption in the Earth-Moon System and elsewhere. Geophys Res Lett 22:583-586.

Wielicki, M.M., Harrison, T.M., and Schmitt, A.K. (2012) Geochemical signatures and magmatic stability of terrestrial impact produced zircon. Earth Planet Sci Lett 321: 20-31.

Wignall, P., Thomas, B., Willink, R., and Watling, J. (2004) Is Bedout an impact crater? Take 1. Science 306:609610 .

Williams, G.E. (1994) Acraman: a major impact structure from the Neoproterozoic of Australia. In Large Meteorite Impacts and Planetary Evolution, GSA Special Paper 293, edited by B.O. Dressler, R.A.F. Grieve, and V.L. Sharpton, Geological Society of America, Boulder, CO, p 209.

Williams, G.E. and Gostin, V.A. (2005) Acraman-Bunyeroo impact event (Ediacaran), South Australia, and environmental consequences: twenty-five years on. Aust J Earth Sci 52: 607-620.

Wilshire, H.G., Offield, T.W., Howard, K.A., and Cummings, D. (1972) Geology of the Sierra Madera cryptoexplosion structure, Pecos County, Texas. In Contributions to Astrogeology Geological Survey Professional Paper 599-H, Washington, DC, $47 \mathrm{p}$.

Wilson, C.W., Jr. (1953) Wilcox deposits in explosion craters, Stewart County, Tennessee, and their relations to origin and age of Wells Creek Basin structure. GSA Bull 64: $753-768$.

Wittmann, A., Kenkmann, T., Schmitt, R.T., and Stöffler, D. (2006) Shock-metamorphosed zircon in terrestrial impact craters. Meteorit Planet Sci 41:433-454. 
Wolbach, W.S., Lewis, R.S., and Anders, E. (1985) Cretaceous extinctions: evidence for wildfires and search for meteoritic material. Science 230:167-170.

Yabushita, S. (1996) Are cratering and probably related geological records periodic? Earth Moon Planets 72:343356.

Yarmolyuk, V.A. (1951) Sobolevskiy crater: Priroda, 6:40-42.

Ye, Q.Z. (2018) Meteor showers from active asteroids and dormant comets in near-Earth space: a review. Planet Space Sci 164:7-12.

Young, K.E., van Soest, M.C., Hodges, K.V., Watson, E.B., Adams, B.A., and Lee, P. (2013) Impact thermochronology and the age of Haughton impact structure, Canada. Geophys Res Lett 40:3836-3840.

Zahnle, K. and Sleep, N.H. (2006) Impacts and the early evolution of life. In Comets and the Origin and Evolution of Life, edited by P.J. Thomas, C.F. Chyba, and C.P. McKay, Springer, Berlin, Heidelberg, pp 207-251.

Zappalà, V., Cellino, A., Gladman, B.J., Manley, S., and Migliorini, F. (1998) Asteroid showers on Earth after family breakup events. Icarus 134:176-179.

Zürcher, L. and Kring, D.A. (2004) Hydrothermal alteration in the core of the Yaxcopoil-1 borehole, Chicxulub impact structure, Mexico. Meteorit Planet Sci 39:1199-1221.
Address correspondence to:

Martin Schmieder

Lunar and Planetary Institute-USRA 3600 Bay Area Blvd

Houston, TX 77058

E-mail: martin@suevite.com

Submitted 22 April 2019

Accepted 19 September 2019

Associate Editor: Christopher McKay

Abbreviations Used

$\mathrm{CA}$-TIMS $=$ chemical abrasion thermal ionization mass spectrometry

ICS = International Chronostratigraphic Chart

LA-ICP-MS = laser ablation inductively coupled plasma mass spectrometry

MSWD $=$ mean square weighted deviation

SHRIMP $=$ sensitive high-resolution ion microprobe

SIMS $=$ secondary ion mass spectrometry 